\title{
Impact of ICTs-in-Agriculture on Rural Resilience in Developing Countries
}

\section{Document Version}

Final published version

Link to publication record in Manchester Research Explorer

\section{Citation for published version (APA):}

Hanson, W., \& Heeks, R. (2020). Impact of ICTs-in-Agriculture on Rural Resilience in Developing Countries. (GDI Development Informatics Working Papers; No. 84).

\section{Citing this paper}

Please note that where the full-text provided on Manchester Research Explorer is the Author Accepted Manuscript or Proof version this may differ from the final Published version. If citing, it is advised that you check and use the publisher's definitive version.

\section{General rights}

Copyright and moral rights for the publications made accessible in the Research Explorer are retained by the authors and/or other copyright owners and it is a condition of accessing publications that users recognise and abide by the legal requirements associated with these rights.

\section{Takedown policy}

If you believe that this document breaches copyright please refer to the University of Manchester's Takedown Procedures [http://man.ac.uk/04Y6Bo] or contact uml.scholarlycommunications@manchester.ac.uk providing relevant details, so we can investigate your claim.

\section{OPEN ACCESS}




\section{Development Informatics}

\section{Working Paper Series}

The Development Informatics working paper series discusses the broad issues surrounding digital data, information, knowledge, information systems, and information and communication technologies in the process of socio-economic development

Paper No. 84

\section{Impact of ICTs-in-Agriculture on Rural Resilience in Developing Countries}

WILLIAM HANSON \& RICHARD HEEKS

2020

ISBN: 978-1-905469-89-5

Published Centre for Development Informatics

by: $\quad$ Global Development Institute, SEED

University of Manchester, Arthur Lewis Building, Manchester, M13 9PL, UK Email: cdi@manchester.ac.uk Web:

View/Download from:

http://www.gdi.manchester.ac.uk/research/publications/di/ 


\section{Table of Contents}

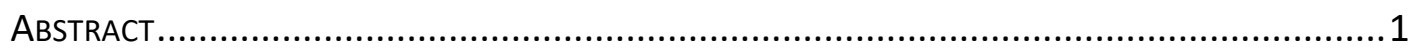

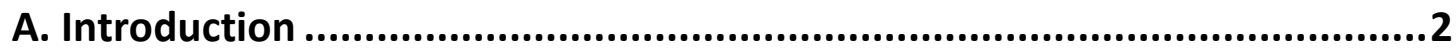

B. Methodology ..........................................................................4

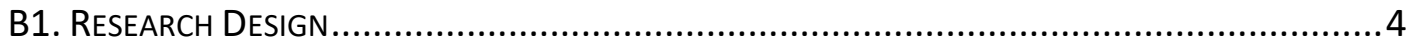

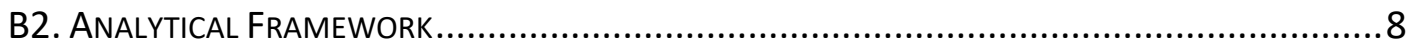

C. Findings: ICT4Ag, Community and Household Resilience ..................... 13

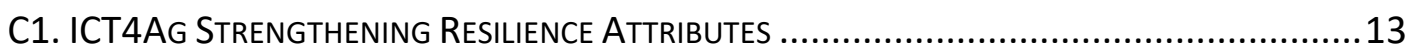

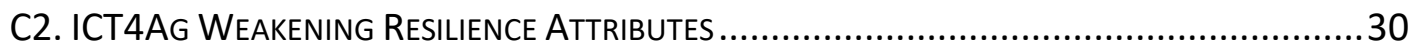

C3. Household AND COMmUnity ResilienCE AtTRIBUtes SummaRY ..................................32

D. Analysis: Explaining ICTs' Impact on Rural Resilience ............................39

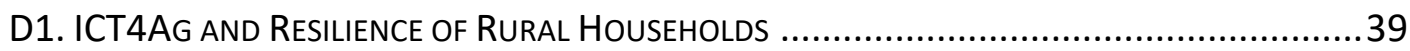

D2. ICT4AG AND RESILIENCE OF RURAL COMMUNITIES ................................................ 41

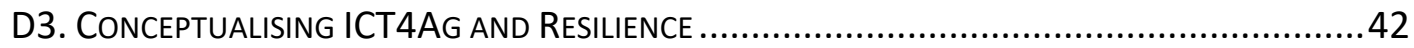

E. Conclusions and Recommendations ......................................................44

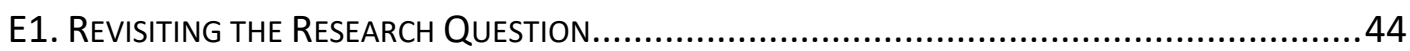

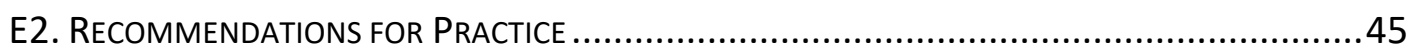

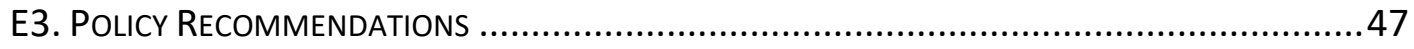

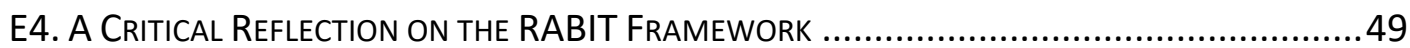

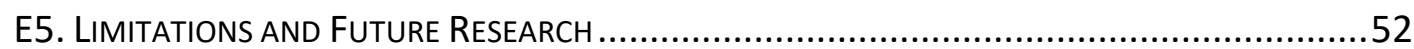

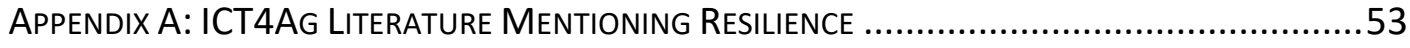

APPENDIX B: SUMMARY OF SYSTEMATIC LITERATURE REVIEW .............................................5

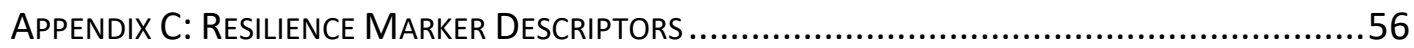

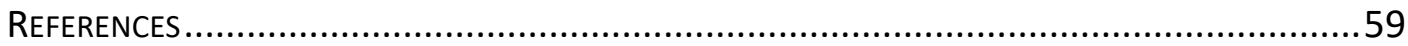




\title{
Impact of ICTs-in-Agriculture on Rural Resilience in Developing Countries
}

\author{
William Hanson \\ Centre for Development \\ Informatics, University of \\ Manchester, UK
}

\author{
\&
}

Richard Heeks

Centre for Development

Informatics, University of

Manchester, UK

\begin{abstract}
Agriculture remains the dominant sector for rural areas in developing countries. However, short-term shocks (e.g. conflict, economic crisis) and long-term trends (e.g. climate change) hamper and can even reverse attempted gains in agricultural productivity and related rural development outcomes. Influenced by the current sustainable development paradigm, it is increasingly acknowledged that, to address this, rural households and communities must strengthen their resilience.
\end{abstract}

Given their growing role in rural livelihoods, information and communication technologies (ICTs) will be a key part of resilience-building. Yet we currently know very little about this. To address this knowledge gap, a systematic literature review was undertaken to establish two things. First, the extent to which use of ICTs-in-agriculture (ICT4Ag) is weakening or strengthening the resilience of rural households and communities in developing countries. Second, an explanation of why the observed impacts are occurring.

Measuring resilience using the RABIT (Resilience Assessment Benchmarking and Impact Toolkit) framework, current reported evidence suggests ICTs are strengthening rural resilience far more than weakening it. However, the impact is highly uneven. Household resilience is built far more than community resilience, and there is a strong differential impact across different resilience attributes: equality in particular is reported as being undermined almost as much as enhanced. A new conceptual model is inductively created to explain some of these outcomes. It highlights the importance of individual user motivations, complementary resources required to make ICT4Ag systems support resilience, and the role of wider systemic factors such as institutions and structural relations.

The paper draws policy/practice conclusions: more equal focus on both household- and community-level resilience, more attention to the resilience-weakening potential of ICTs, ensuring perceived utility of digital applications among rural users, encouraging use of more complex ICT4Ag systems, and looking beyond the technology to make parallel, complementary changes in resource provision and development of rural institutions and social structures. Conclusions are also drawn about the conceptualisation of resilience: better incorporation of agency and power, and greater clarity on resilience system boundaries and indicators.

Overall, we contribute new frameworks, new evidence, new practical guidance and a research agenda for those seeking to strengthen rural resilience through use of ICTs. 


\section{A. Introduction}

Agriculture is the key economic activity in rural areas of developing countries (Deloitte, 2012; Torero, 2014). It therefore presents the best mechanism to alleviate poverty, to improve food security and more generally to improve the livelihoods of rural populations (Mohamad \& Gombe, 2017; World Bank, 2018). However, the relative poverty of rural areas, their lack of access to assets and the relative weakness of their institutions makes them particularly vulnerable to both short-term shocks (e.g. conflicts, economic crisis) and long-term trends (e.g. climate change) (Heeks \& Ospina, 2016a). This vulnerability, in turn, limits the productivity of agriculture and limits associated socio-economic development of rural areas. Influenced by the current development paradigm - sustainable development it is thus increasingly acknowledged that rural areas can only develop if they increase their resilience given its definition as their ability to withstand, recover from, adapt to, and potentially transform amid the change and uncertainty brought on by short-term shocks and longer-term change (Heeks \& Ospina, 2016a; Heeks \& Ospina, 2019; Lipper et al., 2018).

Simultaneously, information and communications technologies (ICTs) such as mobile phones are now regarded as essential enablers to rural development generally and to agricultural development specifically. For example, through digitisation ICTs have reduced the cost, time and risk associated with farmers' purchase- and sales-related journeys (Heeks, 2018; Sife et al., 2010; Martin \& Abbott, 2011). They have improved agricultural value-chain processes (e.g. purchasing and selling) through market information and financial services (Baumüller, 2015; Kikulwe et al., 2014; Munyegera \& Matsumoto, 2016), and can even enhance and change market structure through the removal of intermediaries and the introduction of farmers to supply-chain contracting (Baumüller, 2018; Goyal, 2010; Muto \& Yamano, 2009). Conversely, though, use of ICTs-in-agriculture has also been associated with negative impacts such as inter-community conflicts and inequalities (Baird \& Hartter, 2017; Duncombe, 2014; Krone et al., 2016).

Despite the sizeable literature in this area, Duncombe (2016: 230) concludes that most recent ICTs-and-agriculture research has focused on "...narrow measures of output (market prices, market penetration and so on)...", and that there is a need to establish ICTs' "...broader impact on households, communities and welfare". There is also an identified need to understand the longer-term rather than short-term impact of ICTs-in-agriculture (Duncombe, 2016; Walsham, 2017). This knowledge gap can be seen to apply particularly to understanding the link between ICTs and rural resilience given the broad and longer-term perspective on rural development that resilience offers (Hallegatte et al., 2017; Wilson, 2010). There is a significant literature on agriculture and resilience: for example, a Google Scholar search of "intitle:resilience (intitle:agriculture OR intitle:agricultural)" returned 713 results. But there is very little evidence linking this to ICTs. As detailed in Appendix A, a systematic search was undertaken for literature on ICTs, agriculture and resilience. Review of hits found only 13 relevant papers. Of these, the majority just mention the term "resilience" but without any definition or relevant conceptualisation. Only two relevant items - both the work of Ospina and Heeks - were found. Their work provides some evidence that ICTs-for-agriculture (ICT4Ag) interventions can have an impact on rural resilience, but they evidence this on the basis of just a single pilot study. 
There is therefore an important knowledge gap to be addressed, which this paper encapsulates through its focal research question:

To what extent is the use of ICTs-in-agriculture weakening or strengthening the resilience of rural households and communities in developing countries, and why?

To answer this question, the research reported here focuses on generic resilience that covers all shocks and trends, as opposed to specific resilience that targets individual shocks, such as drought resilience or flood resilience or climate resilience, etc. (Folke et al., 2010). As described in more detail in the next section, it therefore uses a generic resilience framework - the Resilience Assessment Benchmarking and Impact Toolkit (RABIT) framework - developed by Angelica Ospina (Ospina, 2013). Consistent with the wider evidence of both positive and negative impacts of ICTs-in-agriculture, this research addresses both strengthening and weakening of resilience. Consistent with the call by Duncombe (2016) and others, the research will look at resilience of both households and communities.

Four specific objectives will therefore be addressed to answer the research question:

1. To evaluate the extent to which ICTs-in-agriculture literature reports strengthening or weakening RABIT resilience attributes of rural households and communities in developing countries;

2. To analyse and explain the overall impact of ICTs-in-agriculture on rural resilience;

3. To highlight implications for future policies, practice and research in the ICT4Ag domain; and

4. To critically reflect on application of the RABIT framework based on experience of its operationalisation.

The next section of the paper provides details of the research methodology - systematic literature review - and the RABIT-based research perspective. Section C lays out the findings of ICTs' impact on each of the RABIT framework resilience attributes; addressing the first objective above. Analysis and explanation of ICTs' impact on rural resilience is then discussed in Section D; in line with the second objective. The concluding section addresses the last two objectives, making recommendations for policy, practice and future research alongside critique of the framework.

In toto, the paper contributes to our general understanding about the relation between ICTS and resilience; important given the growing role of resilience within the international development agenda alongside the dearth of current research on ICTs and resilience (Heeks \& Ospina, 2019). More specifically, it broadens our understanding of the impact of ICTs-inagriculture; directly exposing the impact that ICTs have on resilience of rural households and communities. 


\section{B. Methodology}

\section{B1. Research Design}

A systematic literature review (SLR) approach was selected as the most appropriate choice to address the research question because it can establish a generalisable and informative evidence-based conclusion using existing evidence (Boland et al., 2017). The review was conducted using Google Scholar and focused on empirical literature on ICT4Ag in developing countries. Google Scholar was used because it has the widest coverage of multi-disciplinary literature (Khabsa \& Giles, 2014), which is crucial since ICT4Ag is inherently multidisciplinary. The SLR was conducted using an adaptation of the preferred reporting items for systematic reviews and meta-analysis (PRISMA) protocol (Moher et al., 2009). There follow details of the inclusion and exclusion criteria, the search strategy, the search results, and the content analysis of the SLR conducted.

\section{B1.1 Inclusion and exclusion criteria}

There are six inclusion criteria utilised in this SLR:

- First, our focus mandates inclusion of studies that only focused on the use of ICTs in rural agriculture ${ }^{1}$ in developing countries ${ }^{2}$. This excluded studies that either focused on high-income countries or urban areas and those that had no focus on the use of ICTs-inagriculture.

- Second, only studies that discussed in some detail the impact of using ICTs-in-agriculture among farming households or communities were included because only such studies could provide the necessary level of detail to answer the research question. This criterion was implemented in two steps: based on the relevance of the study, and based on the level of "impact details" provided by the study. The relevance step assessed whether the study analysed any impacts experienced by farming households or communities due to the use of ICTs-in-agriculture. This was done through screening title, abstract, and full-text of the sources. The "impact details" assessment step was done through full-text reading, and including only those articles that discussed the impact of the use of ICTs-in-agriculture in detail.

- Third, only ICT4Ag empirical literature that used primary data (either alone or alongside secondary data) was considered in order to ensure a direct evidence base.

- Fourth, only those studies that were either open access or were accessible through the University of Manchester library system were considered; otherwise it would not have been possible to read them.

- Fifth, since the adoption and use of ICTs (especially mobile phones) in developing countries has proliferated only since the mid-2000s (Aker \& Mbiti, 2010; Jack \& Suri, 2011), 2005 was set as a boundary for the search period.

- Lastly, only studies written in English were considered.

\section{B1.2 Search strategy}

The search strategy was, initially, created iteratively using generic keywords such as "agriculture" and "information and communication technologies". However, due to the

\footnotetext{
${ }^{1}$ Here, agriculture is understood in a broad sense that comprises farming, animal husbandry, and fishing.

2 Defined as “...those nations identified by the OECD's Development Assistance Committee as low- and middleincome Official Development Assistance recipients" (Heeks, 2018: 10).
} 
challenges of incorporating mobile phones and other ICTs in one search, and the large number of results ${ }^{3}$ returned with generic keywords, formulating various strategies was necessary to retrieve relevant literature. The Google Scholar "intitle" operator was utilised to filter and retrieve articles whose focus was agriculture and ICTs. Moreover, various "intitle" keyword combinations using "AND" or "OR" operators were employed to ensure a more comprehensive search. For example, to retrieve articles focusing on mobile phones, the "intitle:phone OR intitle:phones" search string was used to include both the singular and plural form. The use of the keyword "developing countries" to only identify literature that focussed on developing countries was not included as it did not have any significant influence on the number of results returned. Overall, three search strings were finalised, as shown in Table B1.

\section{Table B1: Search strategy}

\begin{tabular}{|l|l|l|}
\hline \multicolumn{2}{|l|}{ Search Strategy } & Search String \\
\hline 1. & $\begin{array}{l}\text { mobile phones, agriculture } \\
\text { and livelihoods/welfare }\end{array}$ & $\begin{array}{l}\text { (intitle:phones OR intitle:phone OR intitle: "mobile } \\
\text { money") (intitle:livelihood OR intitle:livelihoods OR } \\
\text { intitle:welfare) agriculture }\end{array}$ \\
\hline 2. & $\begin{array}{l}\text { mobile phones, agriculture, } \\
\text { and impact }\end{array}$ & $\begin{array}{l}\text { intitle:phones OR intitle:phone OR intitle: "mobile } \\
\text { money" farm agriculture impact }\end{array}$ \\
\hline 3. & ICTs, agriculture, and impact & $\begin{array}{l}\text { (intitle: "information and communication technology" } \\
\text { OR intitle:"information and communication } \\
\text { technologies") (intitle:agriculture OR intitle:agricultural } \\
\text { OR intitle:farmers) impact }\end{array}$ \\
\hline Time period & 2005 onwards \\
\hline
\end{tabular}

In executing this search, it is acknowledged that it would not deliver every possible relevant source. However, it was designed to produce a sufficiently-large body of evidence to enable relevant conclusions to be drawn.

\section{B1.3 Search results}

The search results are presented in four stages: identification, screening, eligibility, and inclusion; as summarised in Figure B1 using the PRISMA protocol.

Upon execution ${ }^{4}$ of the three search strategies (stage 1 identification), a total of 1,004 articles (50 from search 1; 652 from search 2; and 302 from search 3) were identified. During the second stage (screening), 64 duplicate articles were identified and removed, leaving 940 articles for further screening. Out of the 940 articles, 62 were removed because they could not be retrieved (no access), leaving 878 articles. The titles and abstracts of the remaining articles were screened against the inclusion criteria discussed above, resulting in the removal of a further 653 articles, primarily because they were non-empirical, had no focus on ICTs and agriculture, or had no focus on developing countries. At the third stage (eligibility), full-text of the remaining 225 articles was assessed against the inclusion criteria, and a further 150 articles were removed, mainly because they were either not relevant or

\footnotetext{
${ }^{3}$ For example, a search of 'agriculture "information and communication technology" OR "mobile phone*" impact' returned around 17,500 results.

${ }^{4}$ The search results were executed and extracted between $6^{\text {th }}$ and $15^{\text {th }}$ of June 2019.
} 
did not use primary data. The remaining 75 articles were assessed against the "reported outcome" step two inclusion criterion, and a further 30 articles were removed because the level of impact detail was very limited, leaving 45 articles which were included in the systematic literature review (inclusion stage). Table B2 shows a summary of the 45 final articles included in the systematic literature review grouped by search strategy and published year.

Table B2: Summary of included articles

\begin{tabular}{|c|c|c|c|c|c|c|c|c|c|c|c|c|c|}
\hline \multirow[b]{2}{*}{$\begin{array}{c}\text { Search } \\
\text { strategy }\end{array}$} & \multicolumn{13}{|c|}{ Published year } \\
\hline & 2008 & 2009 & 2010 & 2011 & 2012 & 2013 & 2014 & 2015 & 2016 & 2017 & 2018 & 2019 & Total \\
\hline 1 & & 1 & 1 & 2 & & & 1 & & 1 & 1 & 1 & & 8 \\
\hline 2 & & 2 & 1 & 1 & 4 & 2 & 1 & 7 & 5 & 4 & & 1 & 28 \\
\hline 3 & 1 & & 3 & 1 & 1 & 2 & & & 1 & & & & 9 \\
\hline Total & 1 & 3 & 5 & 4 & 5 & 4 & 2 & 7 & 7 & 5 & 1 & 1 & 45 \\
\hline
\end{tabular}




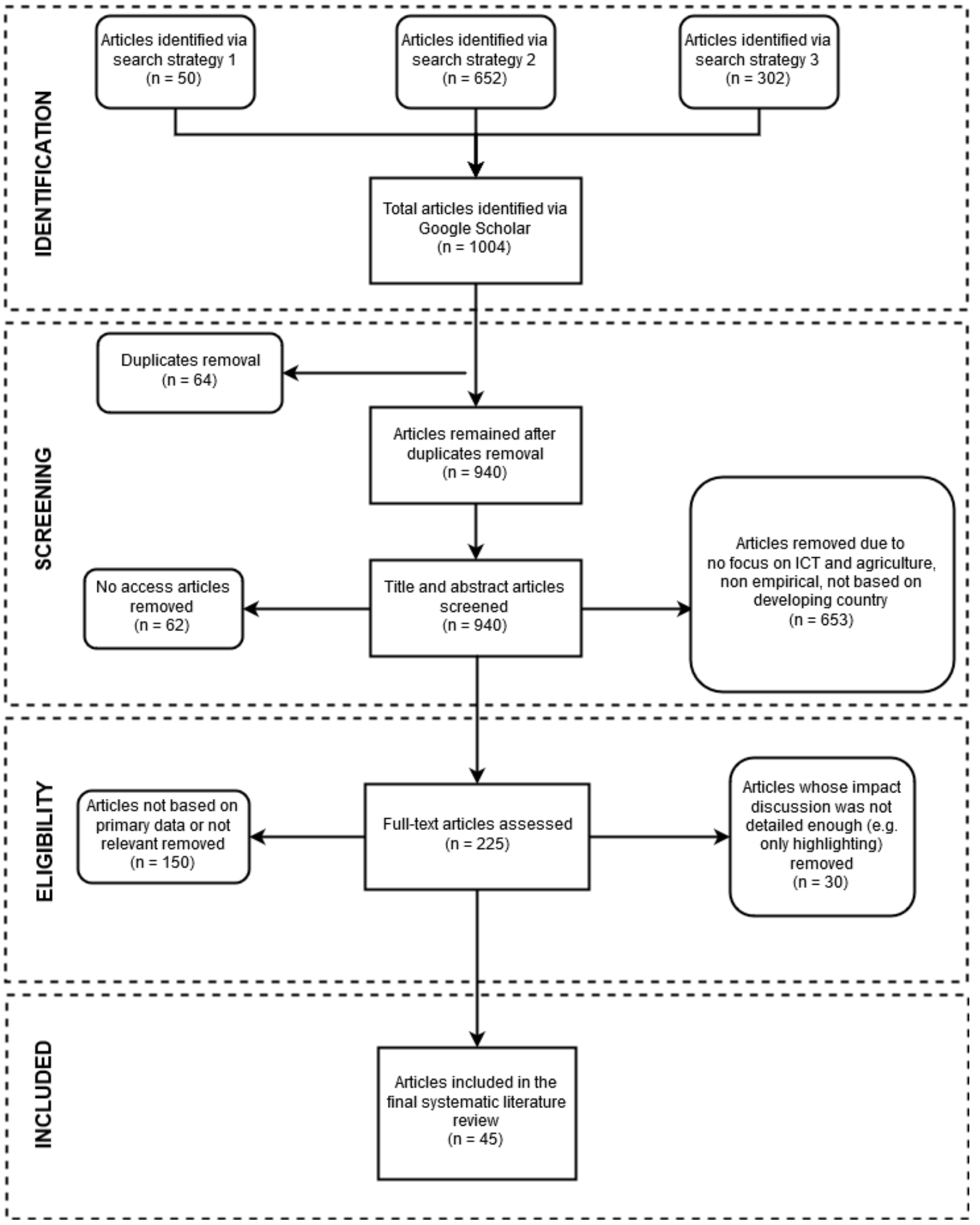

Figure B1: Flow diagram of the selection process based on the PRISMA protocol. Source: adapted from Moher et al. (2009) 


\section{B1.4 Content analysis}

The contents of the articles were analysed using a framework synthesis (Oliver et al., 2008) method - an integrative synthesis approach (Boland et al., 2017) - since the RABIT framework guided data extraction and analysis. An inductive thematic synthesis (Thomas \& Harden, 2008) was used to map data that did not fit into the RABIT framework, which helped to inform critique of the framework. Two types of data categories were extracted: study meta-data (e.g. study characteristics, study duration, country) and study findings (the outcome). Using NVivo, findings were coded against the resilience attributes (for household and communities separately), and summarised using two categories: positive, when findings suggested strengthening; and negative, when they suggested weakening. Initial coding instances were discussed between the two authors to ensure consistency, with some iteration of classification as exact coding meanings were clarified and agreed. Unique instances of sources suggesting weakening and/or strengthening of resilience attributes were then aggregated (see Appendix B), and statistical techniques were used to summarise the overall resilience score for each attribute (see Section C3).

\section{B2. Analytical Framework}

The previous sub-section has looked at the research design; this sub-section moves on to discuss the analytical framework that was applied to the identified and included literature. It provides the foundation of how household and communities are understood, and links them with the resilience conceptualisation through the RABIT framework. It also discusses the link between ICTs and household/community resilience, establishing how ICTs' contribution to resilience can be analysed.

\section{B2.1 Household and community as systems}

Here, household and community are understood as adaptive and open complex systems. This understanding is consistent with the systems thinking approach, where systems are understood to have boundaries (Checkland, 1981). In this case, the livelihood system household or community - contains components (livelihood determinants, capabilities, functionings), processes (functions), and properties (resilience) within the system boundary, while the vulnerability context and development outcomes lie outside the boundary (see Figure B2) (Ospina \& Heeks, 2010). Community and household are also considered open systems because they can influence and be influenced by the external environment: the short-term shocks and long-term trends that are the focus for resilience (Heeks \& Ospina, 2015).

Following this understanding, systems' (i.e. community, household) adaptive capacities can be understood either through their components (assets, institutions, structures) and processes (functions), or through their (sub-)properties - resilience (Ospina \& Heeks, 2010). Although this paper will focus on the latter approach, the two perspectives are just different ways of looking at the same system. Systems' adaptive capacities are derived from their components, processes, and properties (Ospina \& Heeks, 2010); thus, consequently, discussions of assets, institutions, among others, will be done alongside that of the system property: resilience. Next, the concept of resilience as a systemic property is discussed. 


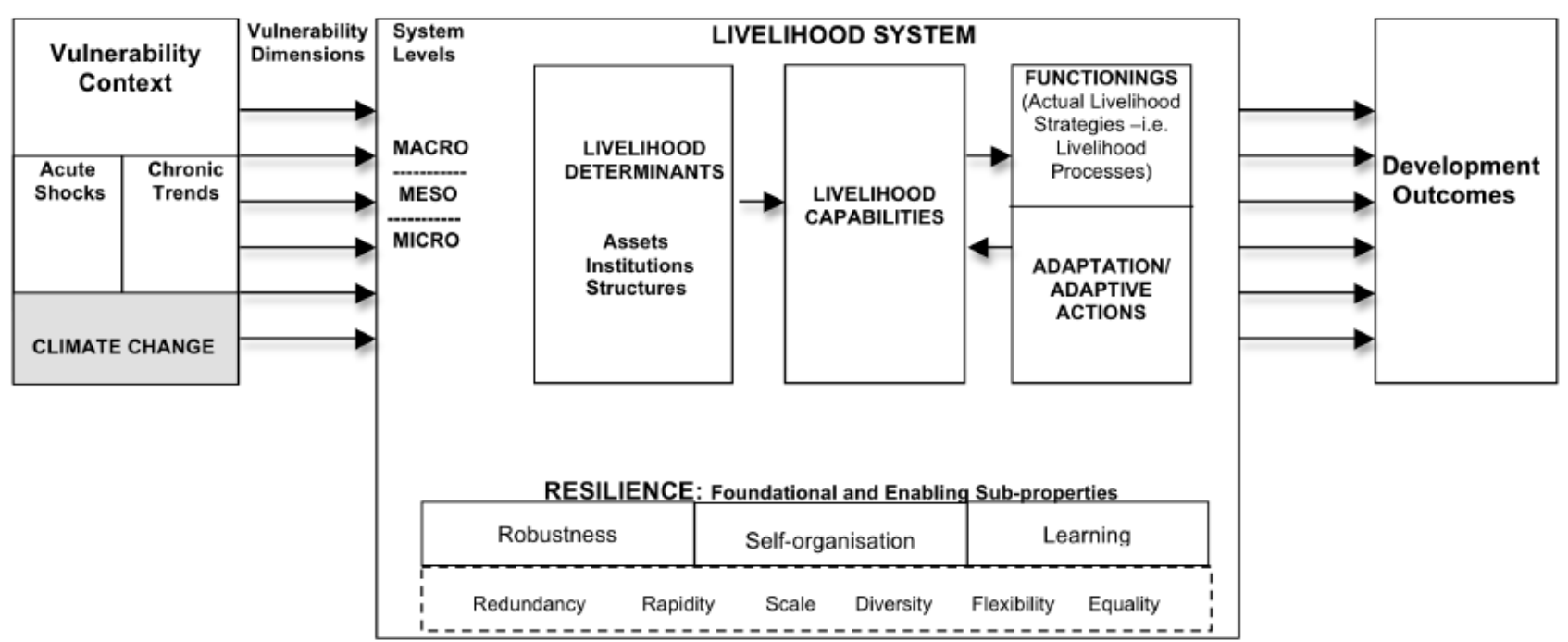

Figure B2: Livelihood systems: components, processes, and properties. Source: Ospina

(2013)

\section{B2.2 Resilience conceptualisation}

As defined in the Introduction, this paper understands resilience as a system property that includes not only withstanding and recovering from short-term shocks but also adaptation and potential transformation in relation to longer-term trends. This understanding, which is the foundation of the RABIT framework, provides a more complete and deep view of resilience - one that is aligned with the concepts of sustainability (Heeks \& Ospina, 2015).

The conceptualisation of resilience as a systemic property can be grouped into two streams: one that understands it as a single "monolithic" property, and one that considers it to have multiple sub-properties (Ospina \& Heeks, 2010). Increasingly, literature is aligned with the latter understanding and it is this literature that forms the basis for the creation of the RABIT framework (for further details, see Ospina, 2013 and Heeks \& Ospina, 2019). From a RABIT perspective, resilient systems are characterised by a series of foundational and enabling sub-properties. The foundational sub-properties (robustness, self-organisation, learning) are fundamental for any resilient system, and thus are directly related to its definition: robustness relates to withstanding; self-organisation to recovery; and together self-organisation and learning are related to the long-term adaptation (Heeks \& Ospina, 2019). The enabling attributes (redundancy, rapidity, scale, diversity, flexibility, equality) are considered crucial facilitators for the operation of the foundational attributes (Heeks \& Ospina, 2015). The last sub-property - equality - is seen as a key measure relating to successful long-term transformation of a system. The definitions for these sub-properties are summarised in Table B3. 
Table B3: Resilience sub-properties' definitions. Source: adapted from Ospina (2013)

\begin{tabular}{|c|c|}
\hline $\begin{array}{l}\text { Resilience } \\
\text { Attributes }\end{array}$ & Definition \\
\hline \multicolumn{2}{|c|}{ FOUNDATIONAL ATTRIBUTES } \\
\hline Robustness & $\begin{array}{l}\text { - The ability of the system to maintain its characteristics and performance } \\
\text { in the face of environmental shocks and fluctuations. }\end{array}$ \\
\hline $\begin{array}{l}\text { Self- } \\
\text { Organisation }\end{array}$ & $\begin{array}{l}\text { - The ability of the system to independently re-arrange its functions and } \\
\text { processes in the face of an external disturbance, without being forced by } \\
\text { external influences. }\end{array}$ \\
\hline Learning & $\begin{array}{l}\text { - The capacity of the system to generate feedback with which to gain or } \\
\text { create knowledge and strengthen skills and capacities. Closely linked to } \\
\text { the system's ability to experiment, discover and innovate. }\end{array}$ \\
\hline \multicolumn{2}{|c|}{ ENABLING ATTRIBUTES } \\
\hline Redundancy & $\begin{array}{l}\text { - The extent to which system resources and institutions are substitutable; } \\
\text { for example, in the event of disruption or degradation. }\end{array}$ \\
\hline Rapidity & $\begin{array}{l}\text { - The speed at which assets can be accessed or mobilised by system } \\
\text { stakeholders to achieve goals in an efficient manner. }\end{array}$ \\
\hline Scale & $\begin{array}{l}\text { - The breadth of assets and structures a system can access to effectively } \\
\text { overcome or bounce back from or adapt to the effects of disturbances. }\end{array}$ \\
\hline $\begin{array}{l}\text { Diversity \& } \\
\text { Flexibility }\end{array}$ & $\begin{array}{l}\text { - The ability of the system to undertake different courses of actions with } \\
\text { the resources at its disposal, while enabling the system to innovate and } \\
\text { utilise the opportunities that may arise from change. }\end{array}$ \\
\hline Equality & $\begin{array}{l}\text { - The extent to which the system provides equal access to rights, resources } \\
\text { and opportunities to its members. }\end{array}$ \\
\hline
\end{tabular}

Apart from the rich conceptualisation of resilience that the RABIT framework provides, this paper employs it because, first, it supports evaluation at both household and community level (Heeks \& Ospina, 2015), since each can be understood, separately, as a system; and second, it has detailed documentation and existing agricultural case analysis, which not only make it relatively easy to operationalise but also justifies its applicability to the current domain.

\section{B2.3 Community and household scope}

This paper analyses resilience at the household (micro) and community (meso) level because each represents an important but distinct aspect of rural resilience (Jones \& Tanner, 2017; Quandt, 2018; Thiede, 2016). Both are conceptualised as systems but they are distinguished on the basis of their boundaries: a household consists of a household head, members and their resources - a co-residential group with associated domestic functions (Bender, 1967); whereas, a community ${ }^{5}$ consists of many households, resources, and community-level institutions, such as local governance, religious institutions, health facilities, among others. Evidence of impact on individual farmer livelihoods and individual households will be categorised under household resilience; evidence of impact on whole

\footnotetext{
${ }^{5}$ Recognising other forms of communities (e.g. of practice, of interest (Robert et al., 2015)), here the focus is on place-based communities - ones that are geographically bound (Wilson, 2012).
} 
communities or community-level institutions / sub-systems (village, community bank, farmer cooperative society, etc.) will be categorised under community resilience. Evidence on community-level resilience must relate to a whole community or community-level institution / sub-system as a unit; it will not merely be evidence of impact on an aggregate of multiple households. Having said this, of course, the effect and connectedness of household resilience to community resilience will be considered.

\section{B2.4 ICTs and community and household resilience}

Given that communities and households are understood as livelihood systems, it is important to establish how ICTs relate to such systems - i.e. whether ICTs are inside or outside the livelihood system - when analysing ICTs' influence on their resilience. From the RABIT framework perspective, ICTs are considered as part of the system components, whereby they interact and influence other components (e.g. assets, institutions) and the system properties - its resilience (see Figure B3) (Ospina \& Heeks, 2010). Therefore, to understand the contribution of ICTs to system resilience, one can analyse the impact of ICTs on each sub-property of resilience (Ospina \& Heeks, 2010; 2015). This is operationalised by evaluating the contribution of ICTs against specific characteristics - "markers" or "indicators" - of each resilience sub-property (see Table B4) (Ospina \& Heeks, 2015; 2019). For example, to analyse the contribution of ICTs to system robustness, three key markers are considered: physical preparedness, institutional capacity, and loose functional coupling. For agriculture, this could involve evaluating how ICTs are helping household/communities prepare for heavy rain for the case of physical preparedness, or how ICTs are enhancing operation and interaction of agricultural community/household institutions, such as community governance bodies, for the case of institutional capacity. It is through this link that ICTs are influencing the resilience and adaptive capacities of households and communities (Ospina \& Heeks, 2010); and thus, it was the foundation of the analysis presented in the following section.

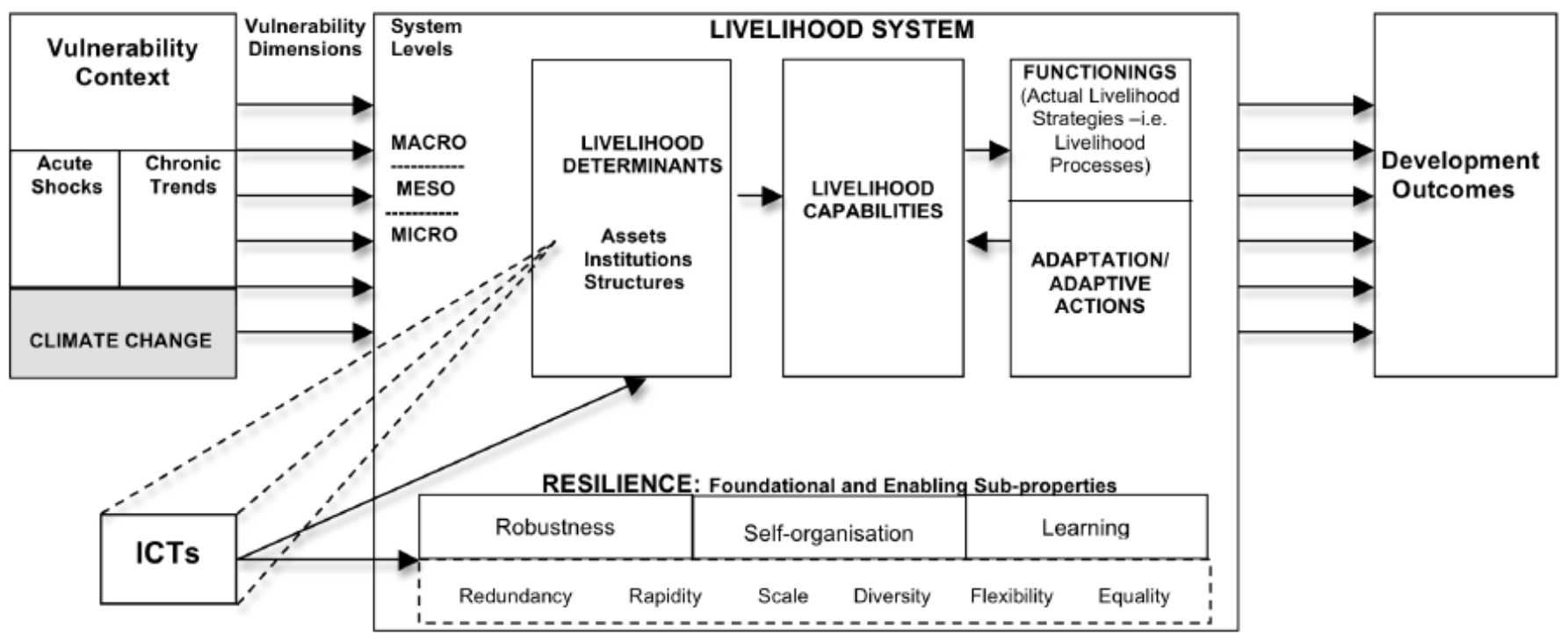

Figure B3: Livelihood system with ICTs as system components. Source: Ospina (2013) 
Table B4: Resilience sub-property indicators. Source: Heeks \& Ospina (2019)

\begin{tabular}{|c|c|}
\hline $\begin{array}{l}\text { Resilience } \\
\text { Attributes }\end{array}$ & Key Markers/ Indicators \\
\hline \multicolumn{2}{|c|}{ FOUNDATIONAL ATTRIBUTES OF HOUSEHOLD/ COMMUNITY RESILIENCE } \\
\hline Robustness & $\begin{array}{l}\text { - Physical preparedness } \\
\text { - Institutional capacity } \\
\text { - Loose functional coupling }\end{array}$ \\
\hline $\begin{array}{l}\text { Self- } \\
\text { Organisation }\end{array}$ & $\begin{array}{l}\text { - Collaboration and consensus-building } \\
\text { - Social networks and trust } \\
\text { - Local leadership }\end{array}$ \\
\hline Learning & $\begin{array}{l}\text { - Capacity building } \\
\text { - Reflective thinking } \\
\text { - New and traditional knowledge }\end{array}$ \\
\hline \multicolumn{2}{|c|}{ ENABLING ATTRIBUTES OF HOUSEHOLD/ COMMUNITY RESILIENCE } \\
\hline Redundancy & $\begin{array}{l}\text { - Resource spareness } \\
\text { - Resource substitutability } \\
\text { - Functional overlaps }\end{array}$ \\
\hline Rapidity & $\begin{array}{l}\text { - Rapid issue detection } \\
\text { - Rapid issue assessment } \\
\text { - Rapid issue response } \\
\end{array}$ \\
\hline Scale & $\begin{array}{l}\text { - Scale of resource access } \\
\text { - Multi-level networks } \\
\text { - Intra-level networks }\end{array}$ \\
\hline $\begin{array}{l}\text { Diversity \& } \\
\text { Flexibility }\end{array}$ & $\begin{array}{l}\text { - Variety of courses of action } \\
\text { - Adaptable decision-making } \\
\text { - Innovation mechanism }\end{array}$ \\
\hline Equality & $\begin{array}{l}\text { - Equality of distribution of assets } \\
\text { - Inclusiveness and participation } \\
\text { - Openness and accountability }\end{array}$ \\
\hline
\end{tabular}




\section{Findings: ICT4Ag, Community and Household Resilience}

Addressing the first research objective, this section is structured into three sub-sections: the first presents findings associated with ICT4Ag strengthening each resilience attribute; followed by evidence of weakening. The final sub-section summarises the overall impact on household and community resilience attributes. A small amount of evidence was challenging to fit into the existing attributes / markers - we discuss this in Section E4.

\section{C1. ICT4Ag Strengthening Resilience Attributes}

This sub-section presents evidence of ICT4Ag strengthening each RABIT resilience attribute. It will start by reporting evidence of foundational attributes then followed by enabling attributes. For each attribute, evidence of both household and community will be presented and summarised. 


\section{C1.1 ICT4Ag and learning}

A. Household

Regarding learning at household level, 62\% of sources (see Figure C1) reported evidence of ICTs strengthening new and traditional knowledge, by facilitating access to and use of agricultural knowledge (e.g. farming techniques, pest management, livestock-keeping techniques), climate change-related knowledge (e.g. climate change influence on agricultural activities), and market-related knowledge (e.g. price and market demand variations per season). There was also evidence of ICTs improving access to information that, when accumulated over a period, can be perceived as knowledge (e.g. price information creating price trend knowledge over time).

$18 \%$ of sources gave evidence of ICTs building capacity to learn, either directly by eliminating obstacles that limit learning (e.g. through the provision of audio-based agricultural knowledge, illiterate farmers can learn through listening (Baardewijk, 2017)), or indirectly by improving skills related to the use of new ICTs, which then facilitate acquisition of new knowledge (e.g. farmers using mobile phone and internet to access new learning opportunities (Manfre \& Nordehn, 2013; Ogbeide \& Ele, 2015)).

As regards reflective thinking, only one of the sources was relevant: reporting evidence of ICTs facilitating identification of gaps and solutions related to pest management (Dey et al., 2008).

Overall, $69 \%$ of sources presented evidence of ICT4Ag strengthening household learning, given a few sources gave evidence relating to multiple learning markers.

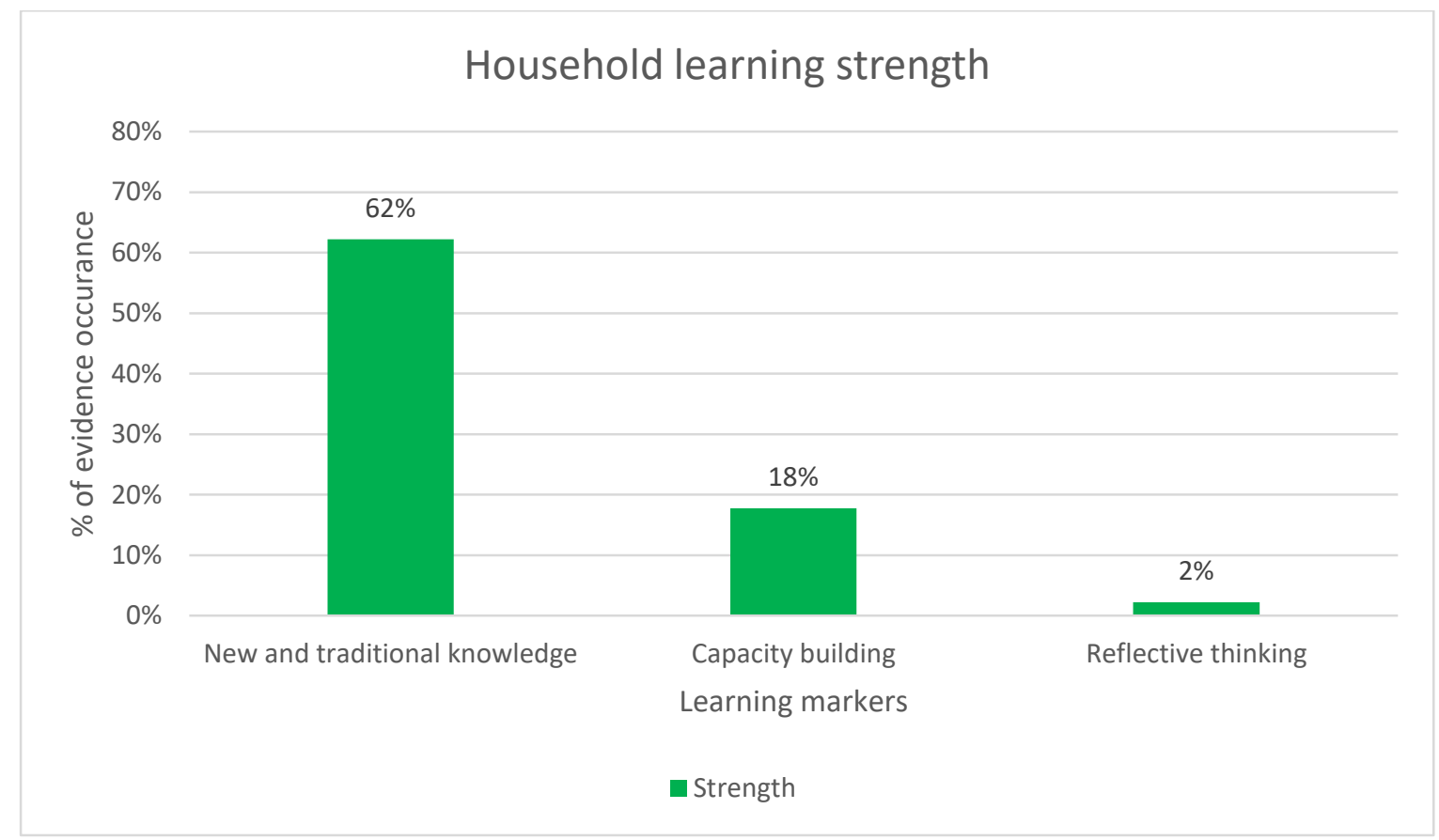

Figure C1: ICT4Ag household learning markers contribution 


\section{B. Community}

Regarding learning at community level, $11 \%$ of sources (see Figure C2) reported evidence of ICTs facilitating the sharing and use of new and traditional knowledge, particularly agricultural production knowledge, among farmers' groups through established networks. Concerning capacity building, one of the sources reported ICTs being used to improve community-level groups' learning opportunities, especially after the skills of using online learning platforms were acquired (Lwoga, 2010). There was no evidence on the reflective thinking marker.

Overall, $11 \%$ of sources gave evidence of ICT4Ag strengthening community learning, as one source gave evidence on the two learning markers.

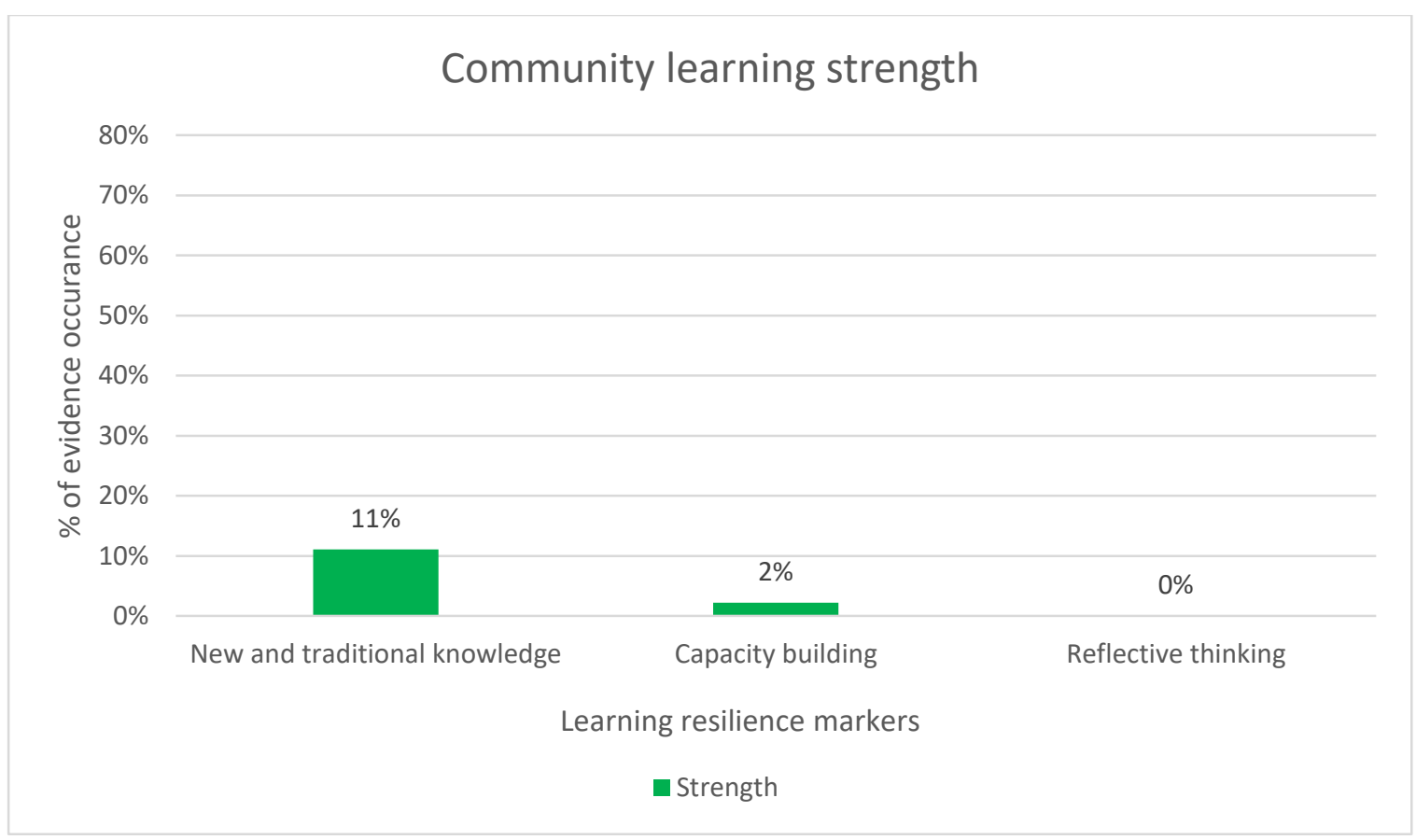

Figure C2: ICT4Ag community learning markers contribution 


\section{C1.2 ICT4Ag and robustness}

\section{A. Household}

A third (33\%) of sources (see Figure C3) provided evidence of ICTs enabling households to continue to function amid changes and uncertainty - institutional capacity - by expanding livelihood strategies (e.g. supporting off-farm activities, agricultural commercialisation (Kirui et al., 2013)), and by increasing agricultural production capacities (in terms of quality, quantity, and diversity), mainly through adoption of improved farming techniques and higher investment in agricultural inputs.

Approximately one-fifth (22\%) of sources suggested that ICTs are improving defensive physical preparedness by providing climate-related information that enables farming households to change their planting patterns, irrigation scheduling, and agricultural inputs (e.g. short-duration seeds), and fishermen to prepare against risks associated with fishing activities (e.g. postponing fishing activities upon receiving alerts of a gathering storm (Mittal et al., 2010; Salia et al., 2011)). There was also evidence of agro-pastoralist households using ICTs (e.g. mobile phones) to prepare against wild animals' attacks (Baird \& Hartter, 2017), and some farming households taking advantage of price information to prepare against food deficit by buying more food when prices are low (Zanello, 2012).

There were only two sources that provided evidence of ICTs strengthening loose functional coupling; that is, enabling farming households to be less dependent on other households, particularly as sources of agricultural information and credits/loans. Overall, around half (53\%) of sources provided evidence of ICT4Ag contributing to household robustness.

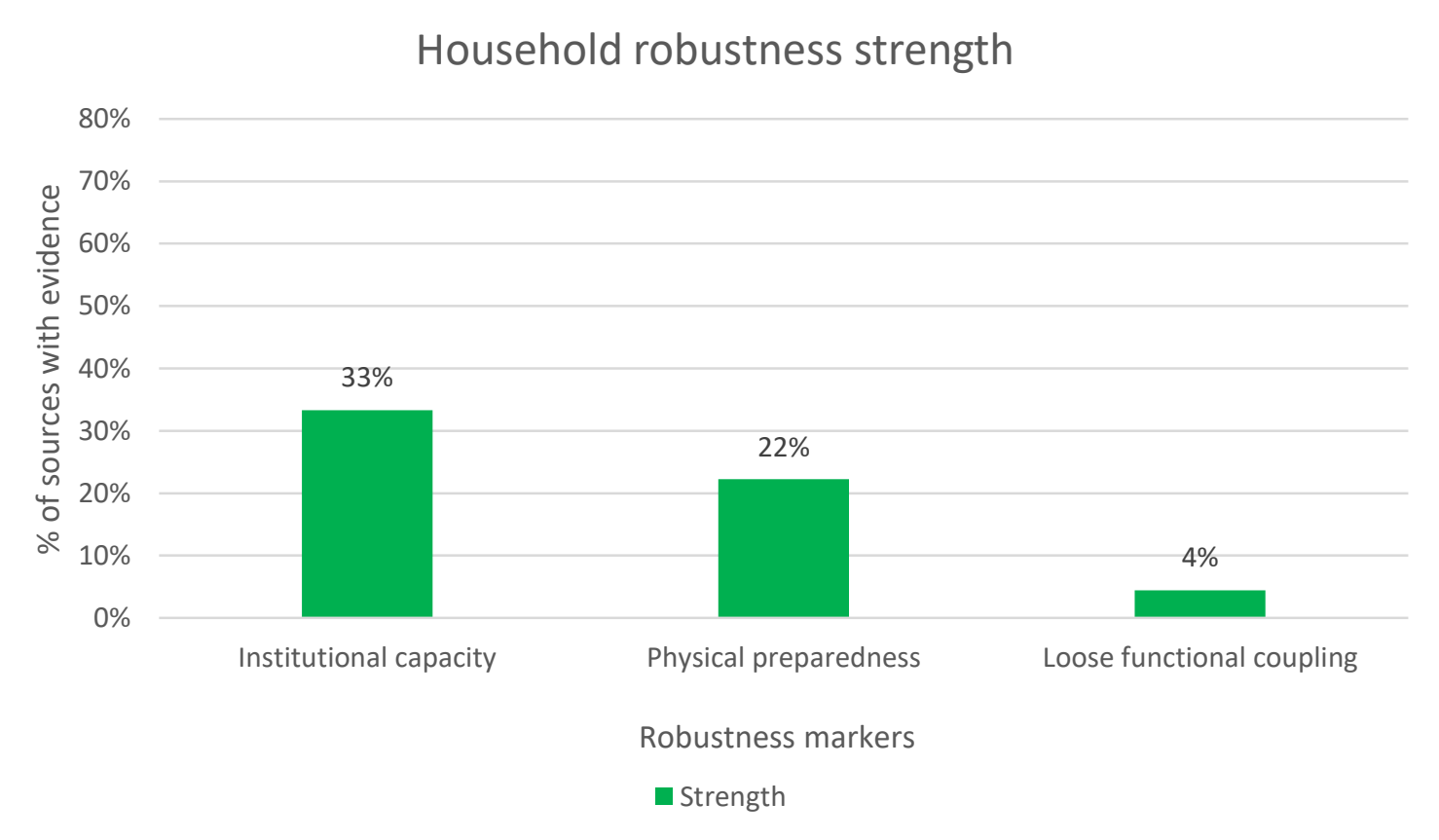

Figure C3: ICT4Ag household robustness markers contribution 
B. Community

At the community level, $9 \%$ of sources (see Figure C4) gave evidence of ICTs strengthening the ability of community-level bodies to continue to function (as a unit) amid change and uncertainty - institutional capacity - by improving their accessibility and reach capacity (e.g. by providing services through the internet and mobile phones), as well as their responsiveness (e.g. responsiveness of pastoralist "community warriors" (Lewis et al., 2016)) and internal management (e.g. management of farmers' group loan payments (Martin \& Abbott, 2011)). No evidence was found relating to loose functional coupling and physical preparedness at community level.

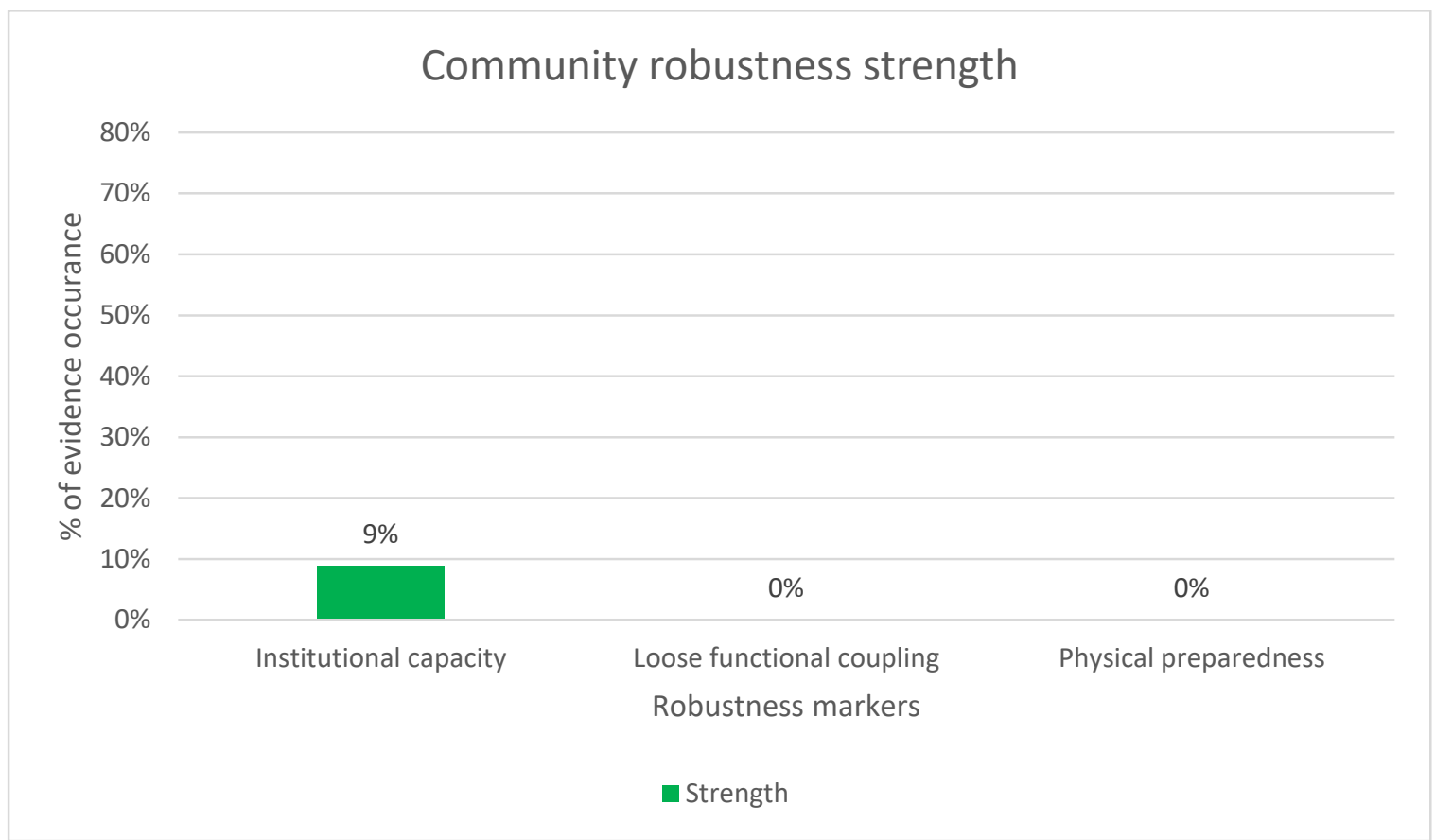

Figure C4: ICT4Ag community robustness markers contribution 


\section{C1.3 ICT4Ag and self-organisation}

A. Household

Looking at self-organisation within households, $22 \%$ of sources (see Figure C5) provided evidence of ICTs building and maintaining social networks and trust within households, as they strengthen bonds and trust among household members.

$7 \%$ of sources gave evidence of ICTs enabling local leadership within households, particularly when used by households' heads to coordinate agricultural activities and provide guidance and directions during emergencies (e.g. when a household member is sick (Furuholt \& Matotay, 2011; Matuha, 2015)).

In the case of collaboration and consensus-building, only two sources provided evidence of ICTs facilitating the building of consensus within households on agricultural activities (e.g. agreeing on farming techniques (Mittal, 2015)) and on emergencies (e.g. when chasing cropraiding animals (Lewis et al., 2016)).

In summary, $27 \%$ of sources provided evidence of ICT4Ag strengthening household selforganisation.

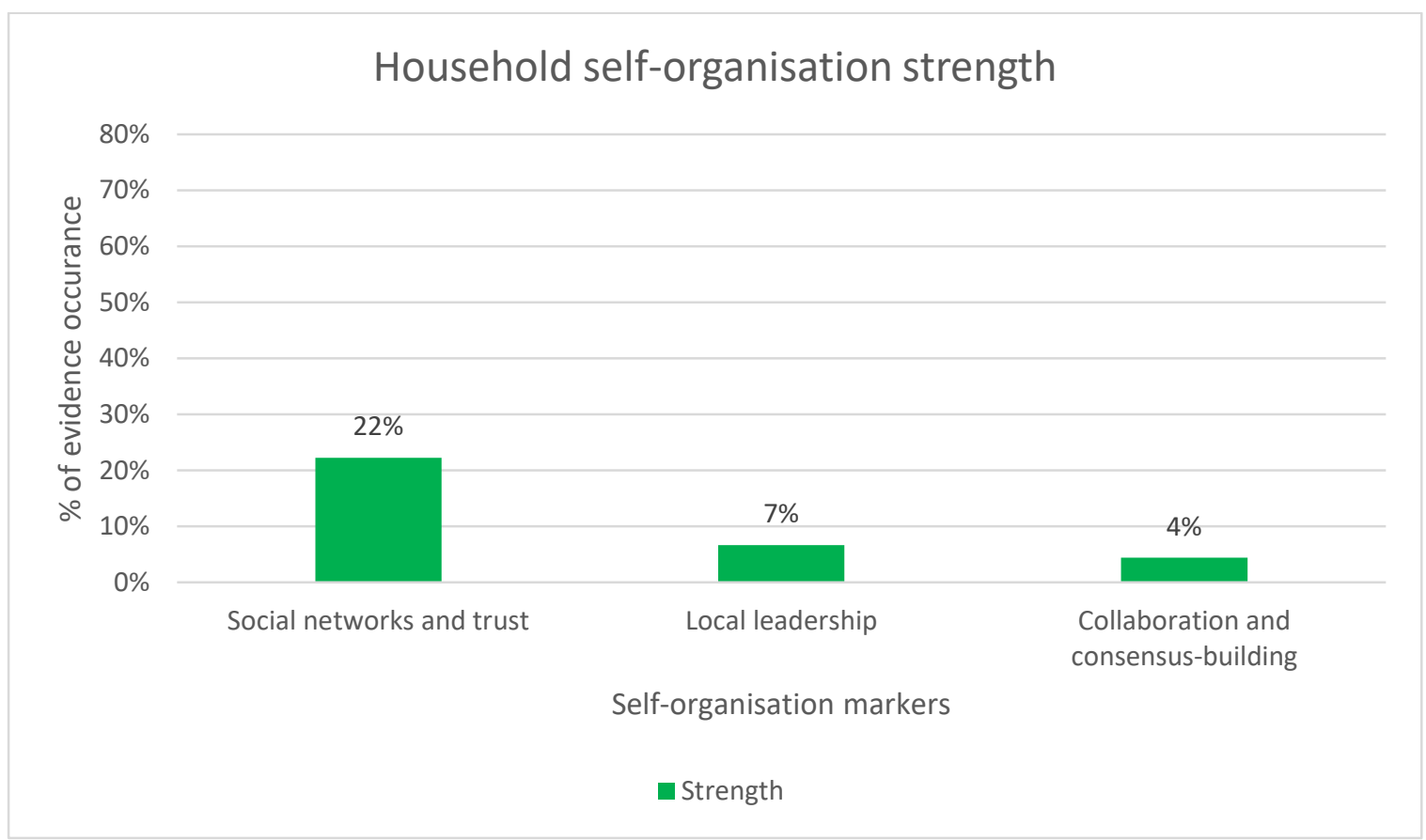

Figure C5: ICT4Ag household self-organisation markers contribution 


\section{B. Community}

At community scope, $20 \%$ of sources (see Figure C6) presented evidence of ICTs strengthening social networks and trust, by facilitating establishment and maintenance of community-level networks, particularly those related to farming and trading.

$18 \%$ of sources reported evidence of ICTs supporting collaboration and consensus-building of community-level group farming activities (e.g. groups of farmers collaborating when negotiating tractor prices (Furuholt \& Matotay, 2011)), and facilitating coordination and management of community-level bodies (e.g. organising and coordinating meetings of farmers' cooperatives (Dannenberg \& Lakes, 2013; Krone et al., 2016)).

$13 \%$ of sources gave evidence of ICTs strengthening local leadership at the community level (e.g. farmer cooperation associations), particularly when used by their leaders to organise and manage the body and its associated activities.

In summary, $38 \%$ of sources reported evidence of ICT4Ag strengthening community selforganisation.

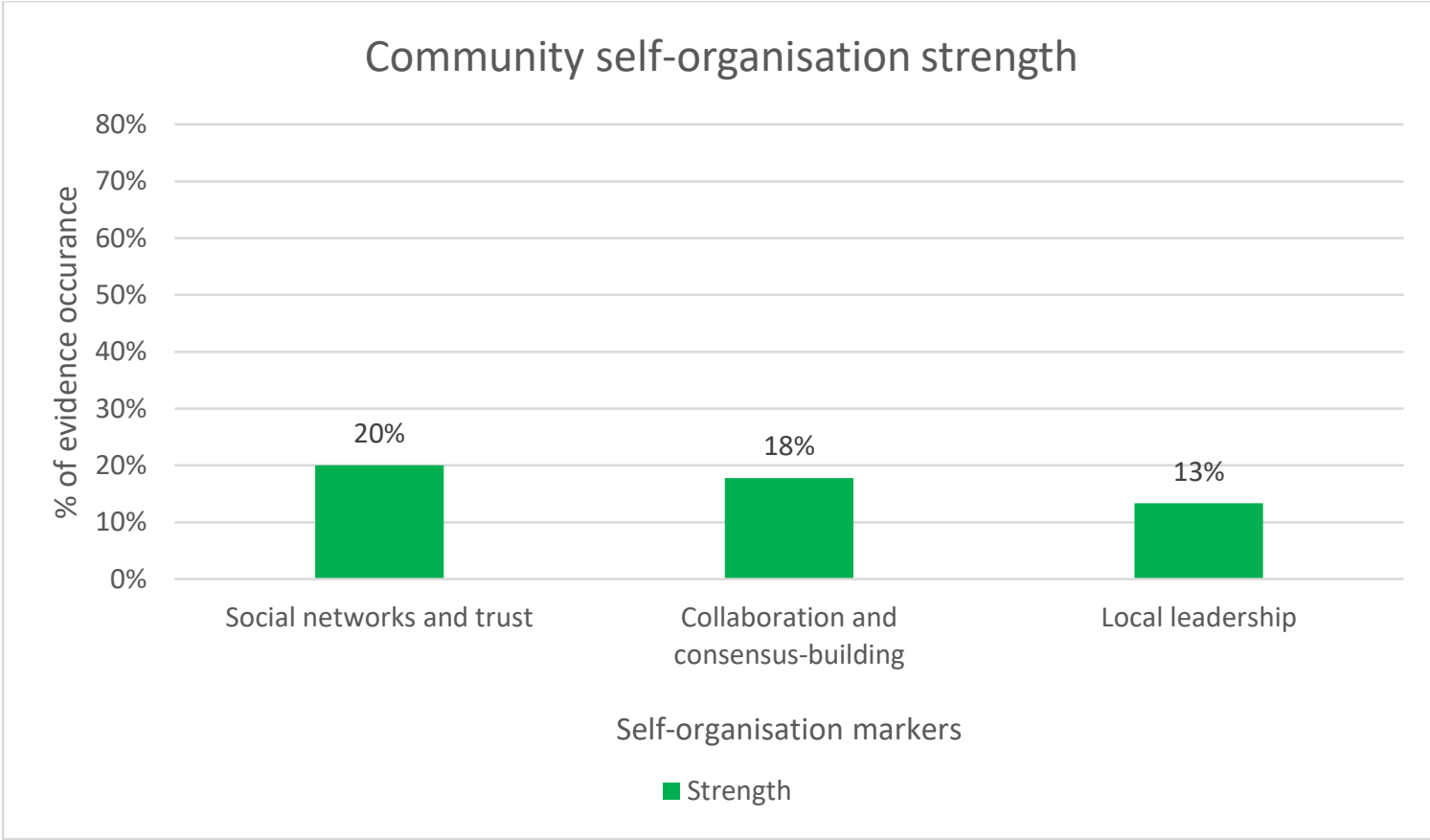

Figure C6: ICT4Ag community self-organisation markers contribution 


\section{C1.4 ICT4Ag and redundancy}

A. Household

As regards redundancy at household level, almost three-quarters (73\%) of sources (see Figure $\mathrm{C7}$ ) presented evidence of ICTs strengthening resource spareness, primarily by reducing the costs and time associated with agricultural activities (e.g. reducing costs and time associated with journeys, information search (Arinloye et al., 2015; Cole \& Fernando, 2012)), and by increasing household income (e.g. through improved productivity, better prices, and increased savings and remittances (Munyegera \& Matsumoto, 2016; Mwakaje, 2010)).

Just over a third (36\%) of sources gave evidence of ICTs strengthening functional overlaps; that is, ICTs offering similar functionality to existing systems/resources. ICTs were achieving this by complementing other sources of agricultural information (e.g. advisory systems, print media (Cole \& Fernando, 2012)), by providing an alternative way of transferring and conducting payments (e.g. through mobile money (Sekabira \& Qaim, 2017a)), or of storing crucial information (e.g. through mobile phone memory cards (Martin \& Abbott, 2011)), and by providing alternative ways of accessing certain services (e.g. mobile phone radio, and accessing the internet through mobile phones (Manfre \& Nordehn, 2013)).

With respect to resource substitutability, $20 \%$ of sources reported evidence of ICTs used to substitute sources of agricultural information (e.g. from intermediaries and buyers to ICTbased systems), journeys (e.g. by making a phone call instead), and sources of loans (e.g. from close relatives/friends to ICT-based loan-offering services (Batista \& Vicente, 2017)).

In summary, the evidence of ICT4Ag strengthening household redundancy was found in 37 of the 45 sources.

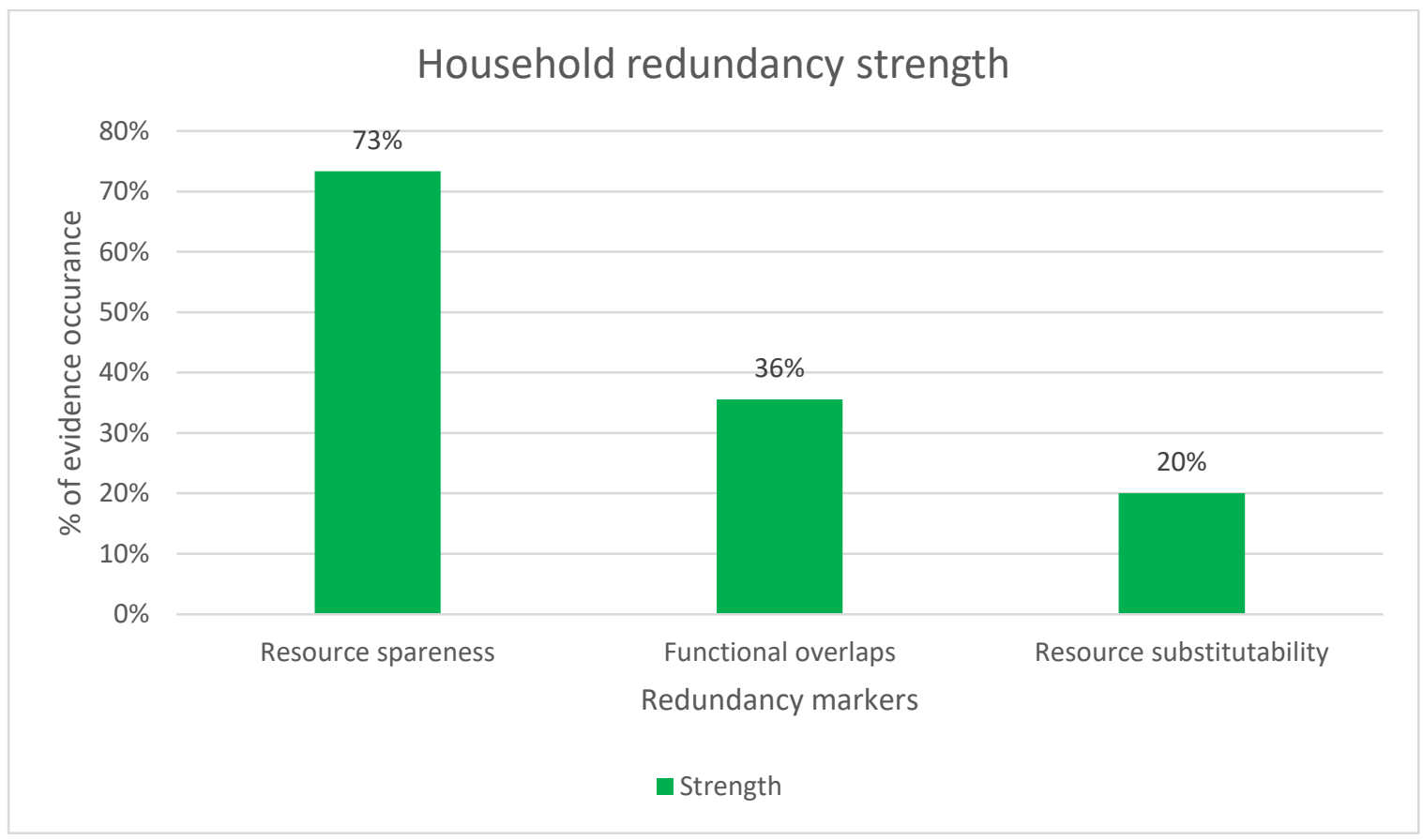

Figure C7: ICT4Ag household redundancy markers contribution 


\section{B. Community}

Regarding redundancy at community level, $9 \%$ of sources (see Figure C8) provided evidence of ICTs facilitating functional overlap, particularly by enabling community-level bodies (e.g. community agricultural radio stations) to provide parallel systems that offered agricultural information, partly by supporting redundant channels (e.g. internet and mobile-based (Ajwang, 2014)), and partly by complementing other traditional sources (e.g. advisory/extension services). Other related data shows that farmers' groups are also using mobile money-based payment as an alternative to cash-based payment (Dannenberg \& Lakes, 2013).

In only two of the sources was there evidence of ICTs strengthening resource spareness at community level, specifically by facilitating collaborations that resulted in reduced costs associated with agricultural inputs (e.g. hiring tractors (Furuholt \& Matotay, 2011)), and improved income attributed to (group) bulk marketing (Masuki et al., 2010).

Concerning resource substitutability, only one of the sources provided evidence of a community-level body using ICTs to substitute sources of information (using the internet instead of its internal library (Lwoga, 2010)).

In summary, $13 \%$ of sources presented evidence of ICT4Ag strengthening community redundancy.

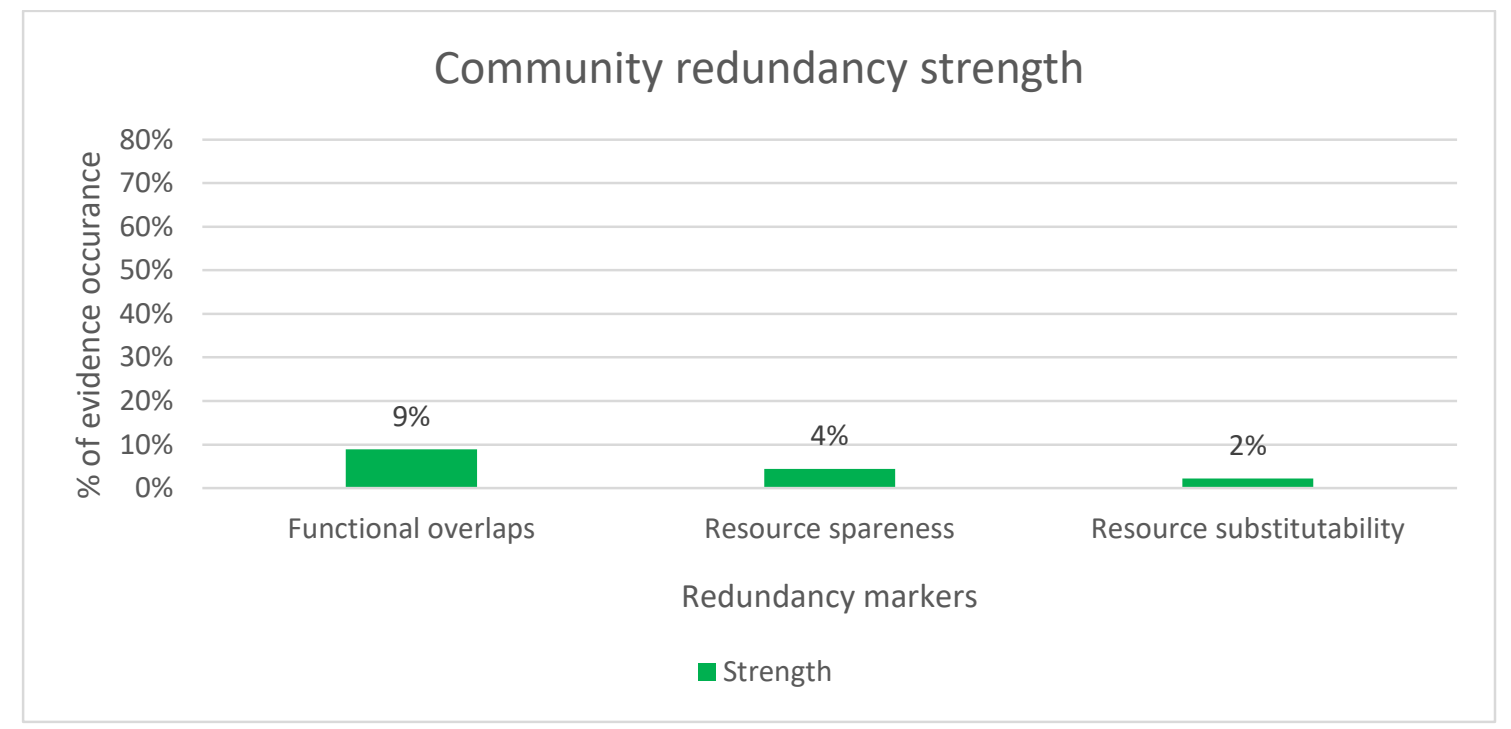

Figure C8: ICT4Ag community redundancy markers contribution

\section{C1.5 ICT4Ag and diversity \& flexibility}

A. Household

In the case of diversity \& flexibility at household level, just over half (56\%) of sources (see Figure (9) presented evidence of ICTs strengthening adaptable decision making, especially by facilitating better decision making in relation to agricultural production (e.g. decisions on the type of inputs to use, the time of planting, the type of crops to plants), and marketing (e.g. amount of crops to harvests, where to sell, and what price to sell at). 
Approximately half (53\%) of sources gave evidence of ICTs strengthening households' ability to take a variety of courses of actions in response to challenges and opportunities, especially by enhancing flexibility in agricultural production (e.g. by promoting the cultivation of diverse crops and the adoption of new and superior farming techniques (Baumüller, 2015; Manfre \& Nordehn, 2013)), by supporting diverse sources of income (e.g. promoting commercial farming, increasing off-farm income, facilitating savings and remittances (Kirui et al., 2013; Sekabira \& Qaim, 2017a)), and by increasing market flexibility (e.g. selling to multiple different markets).

9\% of sources reported evidence of ICTs strengthening innovation mechanisms; in other words, ways through which households access innovative ideas, partly by enabling linkages/networks which then serve as sources of innovative ideas (e.g. farmers through links with banks had access to innovative ideas about international farming quality standards (Dannenberg \& Lakes, 2013)), and partly as direct channels through which households access innovative ideas (e.g. through mobile push-based systems farmers were acquiring more innovative ideas (Baardewijk, 2017)).

In summary, evidence of ICT4Ag strengthening household diversity \& flexibility was presented by 32 out of the 45 sources.

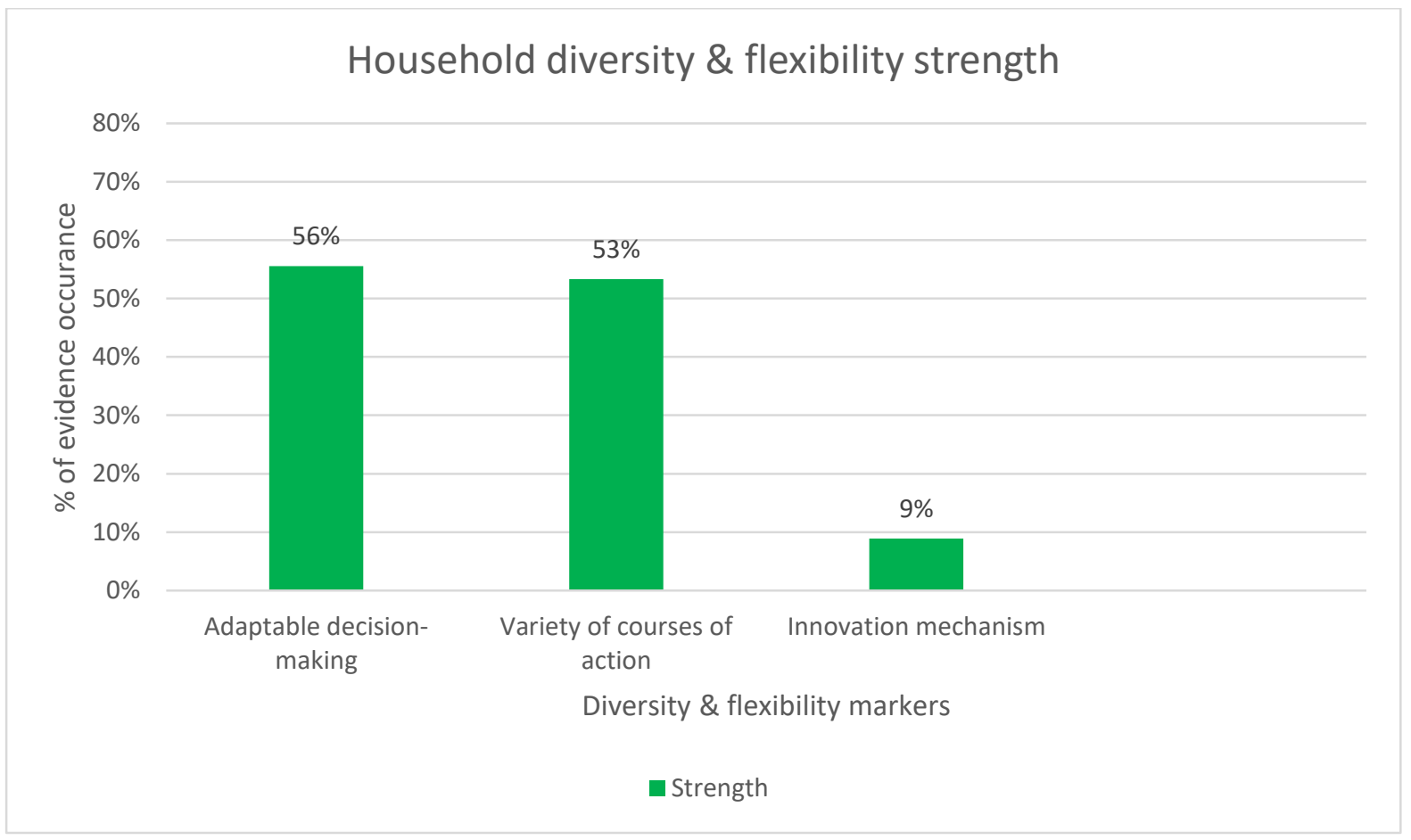

Figure C9: ICT4Ag household diversity \& flexibility markers contribution 


\section{B. Community}

At community scope, only two of the sources (see Figure C10) provided evidence of ICTs strengthening the ability of community-level bodies to make better decisions, particularly by increasing the speed of sharing information (e.g. by increasing the speed of sharing information about health diagnosis (Martin \& Abbott, 2011)) and by improving accessibility of information (e.g. village-level market information (Tadesse \& Bahiigwa, 2015)).

Similarly, there were just two sources that provided evidence of ICTs enabling communitylevel bodies to take new courses of actions when responding to challenges and opportunities. For example, due to information obtained through ICTs, farmer groups started using group loan sharing and group savings to improve their financial capital (Piontak, 2012).

There was no evidence found of ICTs strengthening innovation mechanisms at the community level.

Overall, only three of the sources gave evidence of ICT4Ag strengthening community diversity \& flexibility.

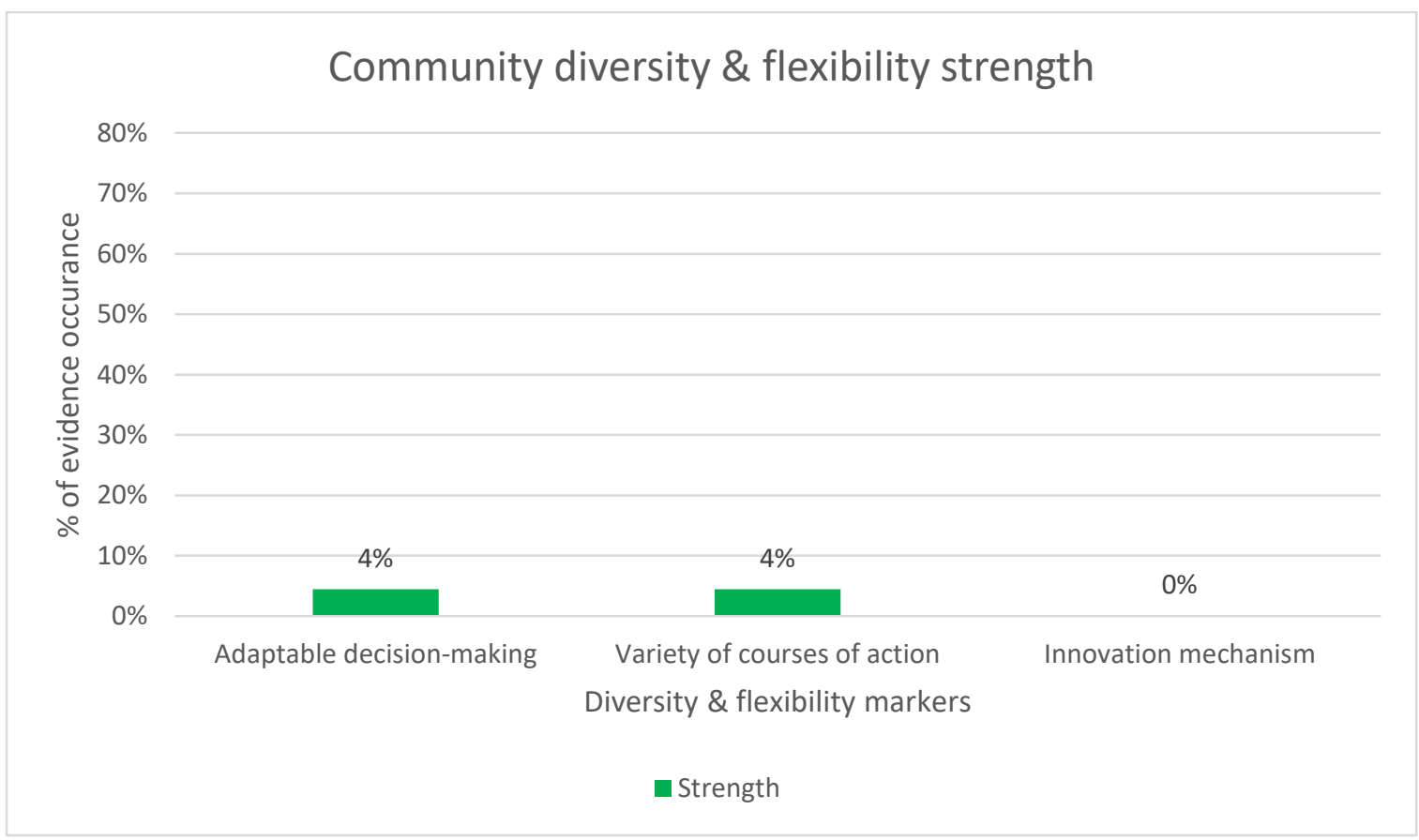

Figure C10: ICT4Ag community diversity \& flexibility markers contribution 


\section{C1.6 ICT4Ag and rapidity}

A. Household

With respect to rapidity at household level, nearly half (47\%) of sources (see Figure C11) reported evidence of ICTs strengthening rapid issue response, particularly by increasing the speed at which household members respond during agricultural activities (e.g. input mobilisation, livestock emergency care provision, pest outbreak management), and marketrelated activities (e.g. searching for buyers, selling produce, mobilising suppliers and buyers).

Just above a third (36\%) of sources provided evidence of ICTs strengthening household rapid issue detection, primarily by increasing the speed at which household members access agricultural information (e.g. availability of inputs, farming best practices, weather information), and market information (e.g. market price information, market demands).

Only two sources gave evidence of ICTs facilitating household rapid issue assessment, mainly by enhancing the speed at which households make market-related decisions (e.g. changing produce prices, changing buyers (Ajwang, 2014; Mwantimwa, 2019)).

Taken together, $58 \%$ of sources gave evidence of ICT4Ag strengthening household rapidity.

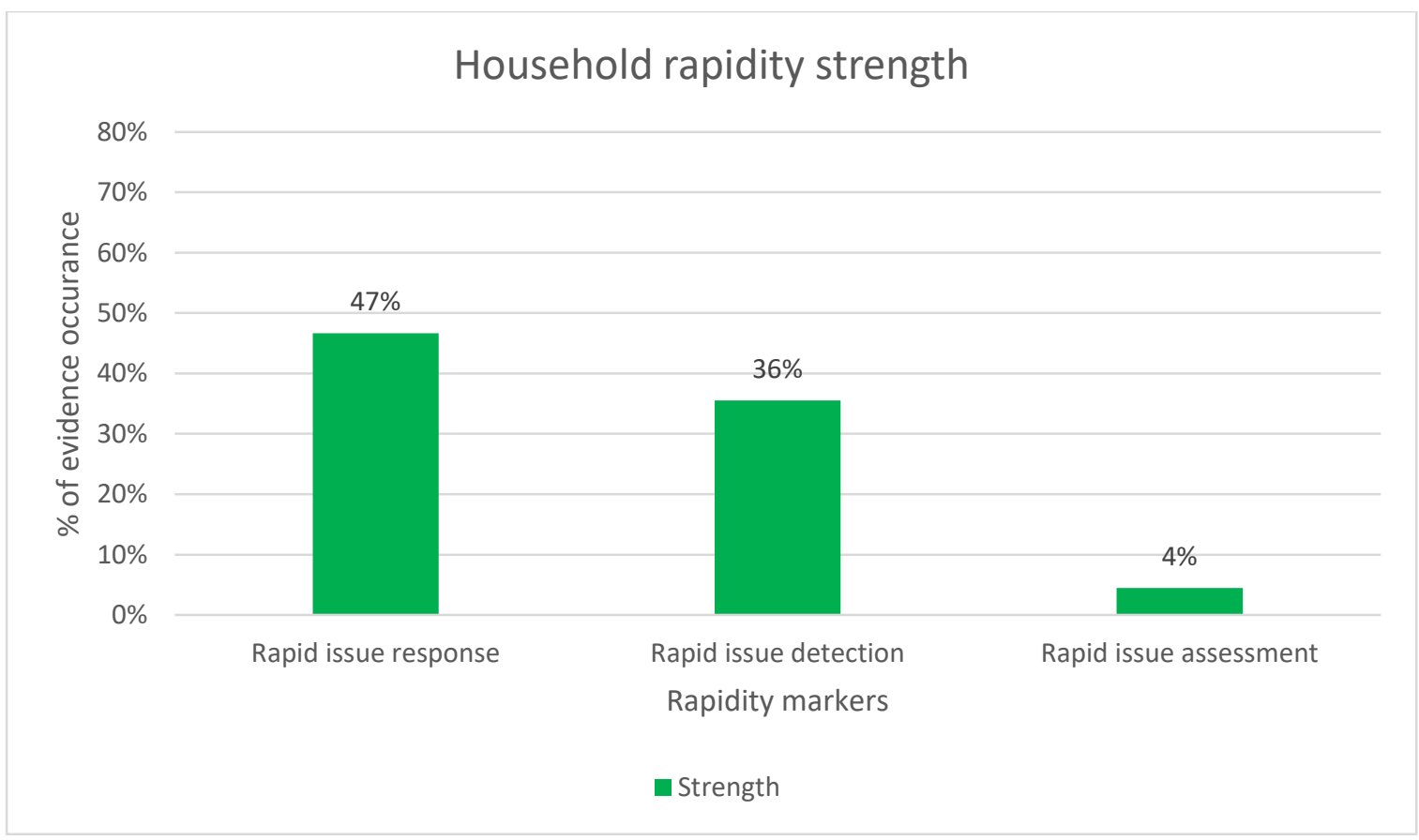

Figure C11: ICT4Ag household rapidity markers contribution 


\section{B. Community}

At community level, $7 \%$ of sources (see Figure C12) reported evidence of ICTs improving community rapid issue response, particularly by enhancing the speed of mobilisation of community-level bodies when responding to agricultural emergencies (e.g. when dealing with wild animals (Lewis et al., 2016), managing livestock disease outbreak (Masuki et al., 2010)) and during community engagements (e.g. community meetings, trainings (Piontak, 2012)).

Only one source provided evidence of ICTs improving rapid issue detection at a community level, particularly time-sensitive issues (e.g. disease outbreaks (Martin \& Abbott, 2011)), as the speed of sharing information among community-level bodies is enhanced.

There was no evidence of ICTs strengthening rapid issue assessment at the community level.

In summary, $9 \%$ of sources provided evidence of ICT4Ag strengthening community rapidity.

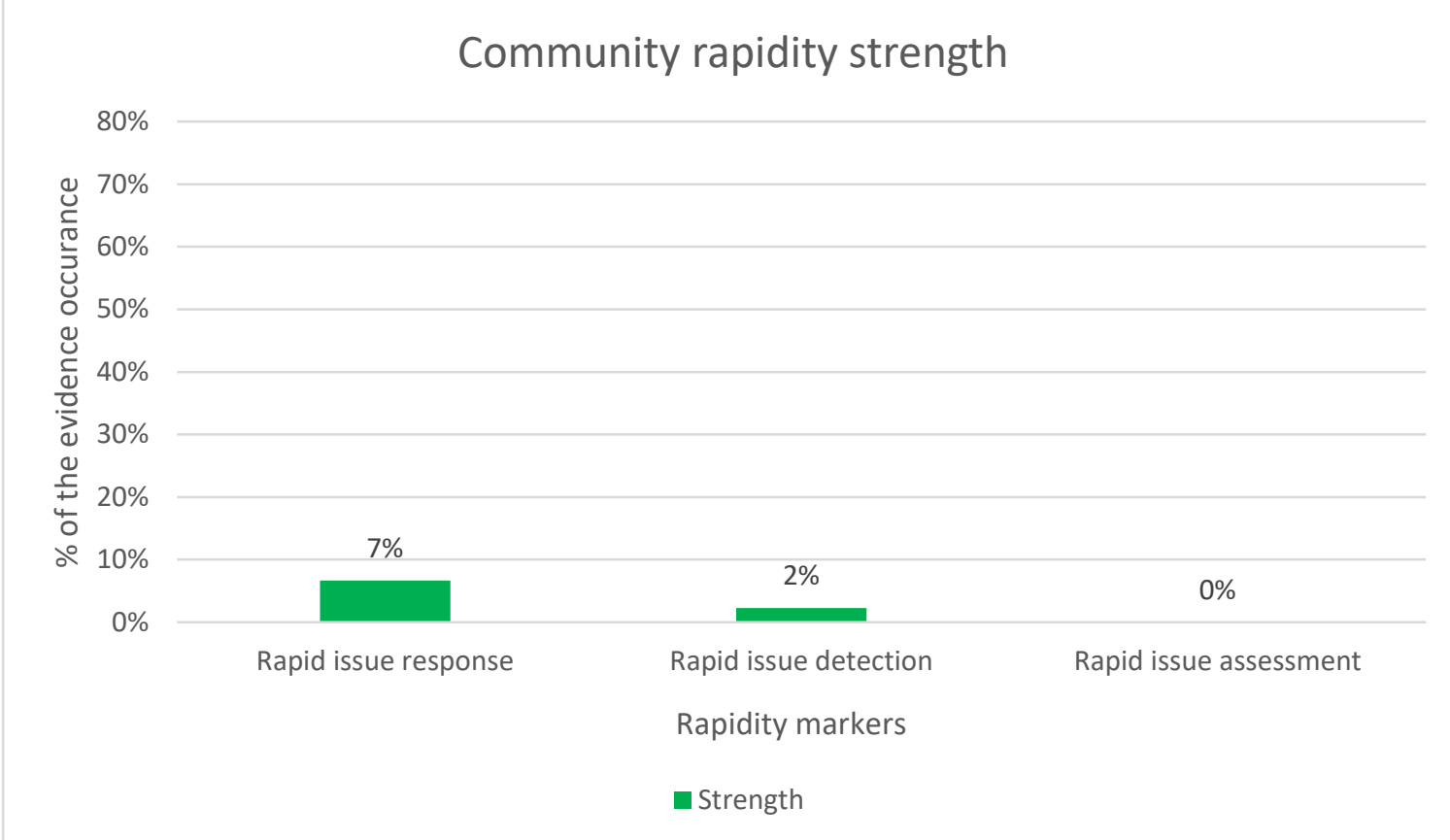

Figure C12: ICT4Ag community rapidity markers contribution 


\section{C1.7 ICT4Ag and equality}

\section{A. Household}

Looking at household equality, $36 \%$ of sources (see Figure C13) reported evidence of ICTs strengthening inclusiveness and participation of households and their members, but only in relation to external not internal functions. This was particularly by improving access to markets (e.g. by connecting with buyers) and acquisition of new agricultural knowledge (e.g. best practices, climate change implications). There was also evidence of ICTs increasing bargaining power (e.g. through knowledge of market price), and improving ownership, access, and use of ICTs and ICT-based services (e.g. ownership and use of mobile phones, use of mobile money services).

Only one source reported evidence of ICTs improving the distribution of assets within households, whereby a notable increase in ownership of productive assets was observed among women with mobile phones (Sekabira \& Qaim, 2017b).

There was no evidence of ICTs strengthening openness and accountability at the household level.

Collectively, $36 \%$ of sources reported evidence of ICT4Ag strengthening household equality.

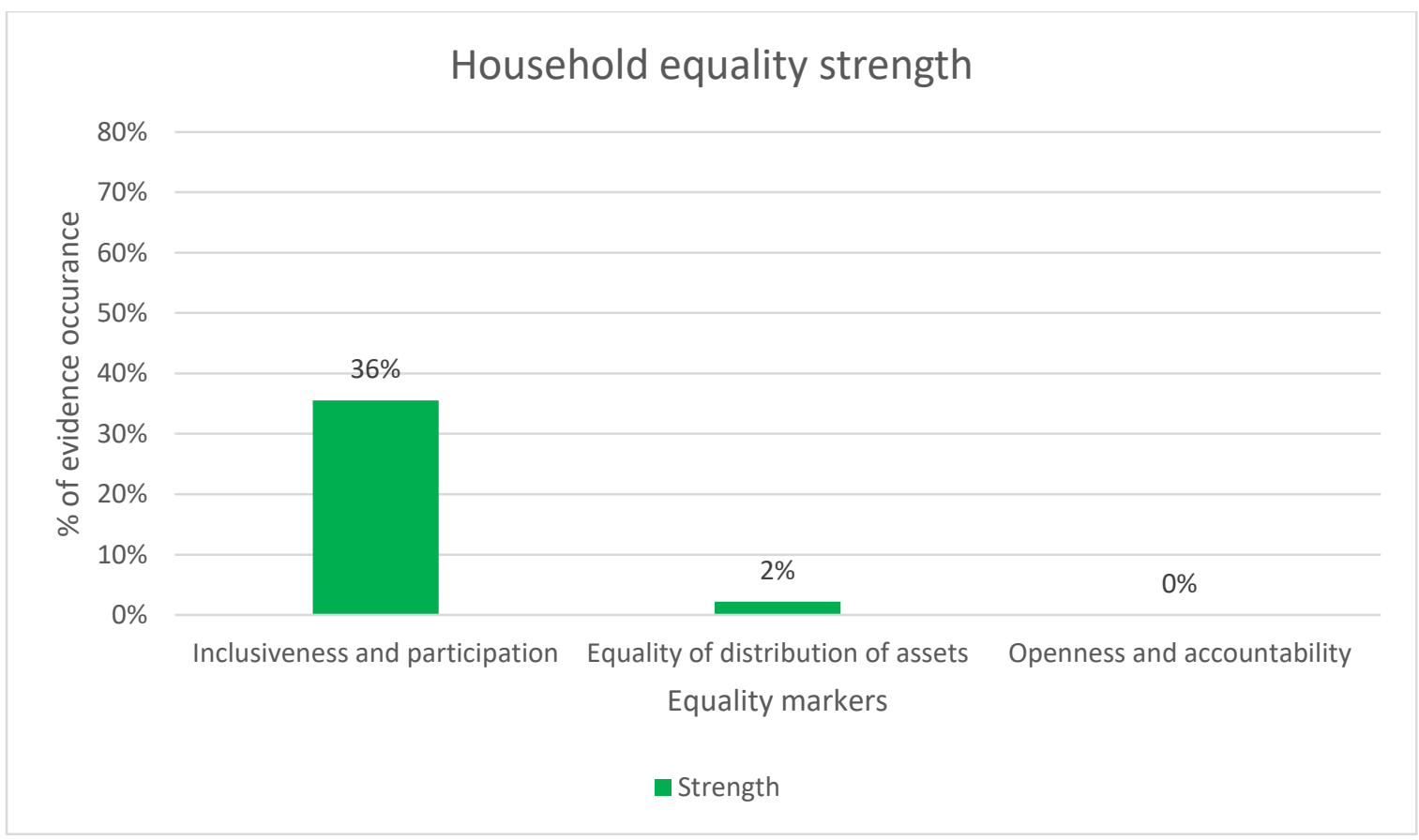

Figure C13: ICT4Ag household equality markers contribution 


\section{B. Community}

Regarding equality at community level, $11 \%$ of sources (see Figure C14) gave evidence of ICTs improving inclusiveness and participation of marginalised groups within communities, particularly by facilitating acquisition of agricultural knowledge among underprivileged groups (e.g. women), by promoting financial inclusion of remote areas (e.g. through the expansion of mobile money (Mtega \& Msungu, 2013)), and by connecting marginalised villages to markets (e.g. through network coverage expansion (Muto \& Yamano, 2009)).

There was only one source that gave evidence of ICTs improving equality of distribution of assets; specifically, the more-equal distribution of profits, obtained from agricultural sales, between community groups (e.g. farmers and intermediaries), as market prices become more open (Furuholt \& Matotay, 2011).

Similarly, only one of the sources presented evidence of ICTs promoting accountability and openness among farmer groups; when integrated into group meetings to facilitate the sharing of information. For example, a mobile phone speaker was being used during group meetings so that all members could hear the information being provided (Martin \& Abbott, 2011).

Overall, $16 \%$ of sources provided evidence of ICT4Ag improving community equality.

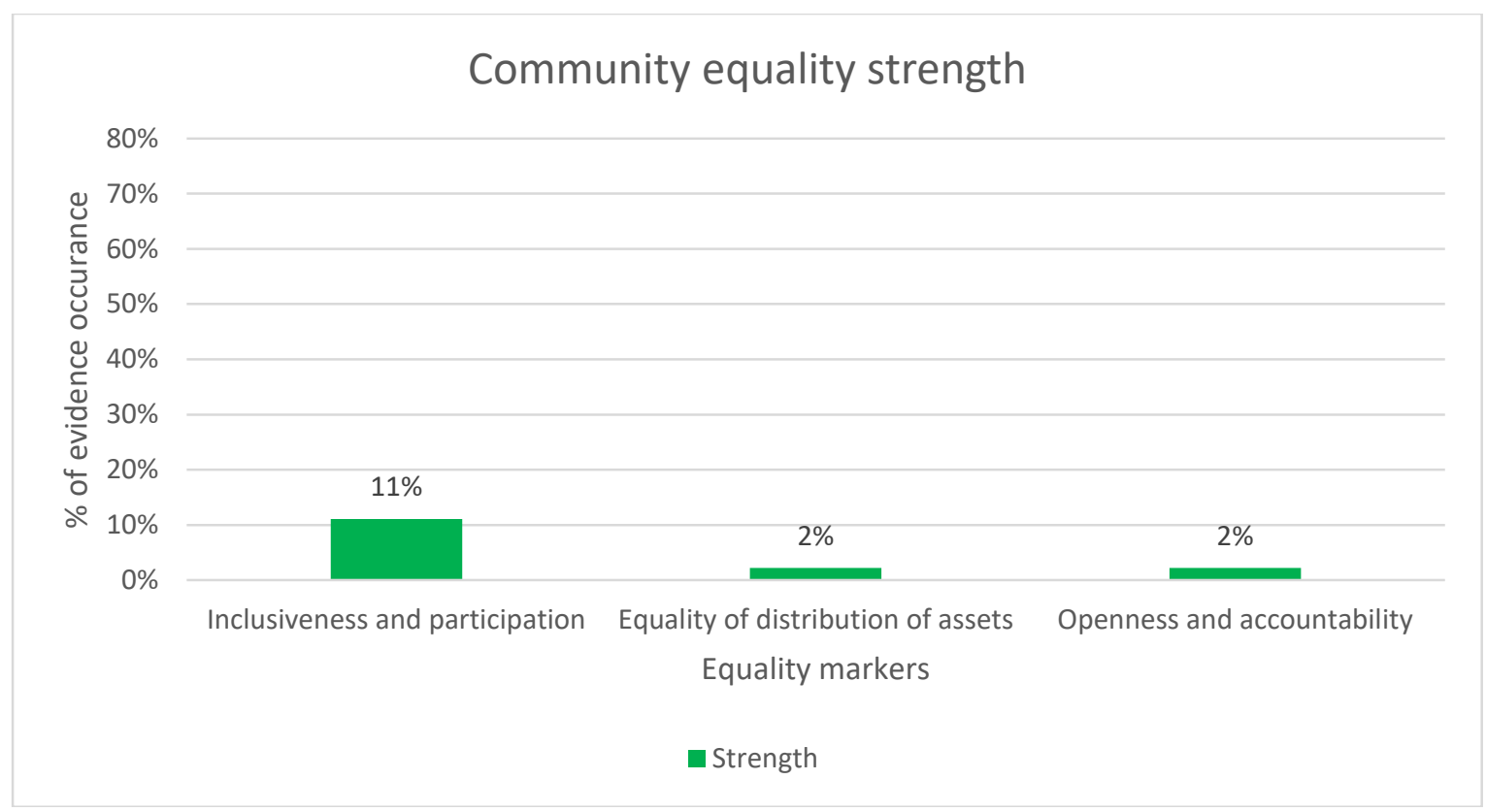

Figure C14: ICT4Ag community equality markers contribution 


\section{C1.8 ICT4Ag and scale}

\section{A. Household}

As regards scale at household level, just over half (56\%) of sources (see Figure C15) gave evidence of ICTs strengthening scale of resource access, mainly by improving households' access to a wide range of markets and sources of market information (e.g. customers from other regions, diverse sources of market prices and demands information), and by enhancing access to a variety of sources of agricultural information (e.g. from mobile-based platforms, radio, extension services) and agricultural inputs (e.g. accessing pesticides and fertiliser from a wide range of suppliers (Furuholt \& Matotay, 2011; Martin \& Abbott, 2011)).

$18 \%$ of sources presented evidence of ICTs strengthening multi-level networks, particularly by facilitating the building of networks/linkages with buyers, suppliers and traders who are outside the immediate community, either through formal contracts (e.g. through contract farming platforms (Baumüller, 2015)) or through non-formal means (e.g. through mobilebased communication linkage (Dannenberg \& Lakes, 2013; Krone et al., 2016)).

$11 \%$ of sources provided evidence of ICTs strengthening intra-level networks, specifically by facilitating the establishment of networks with buyers, suppliers and community-level bodies found within their immediate community.

In summary, $60 \%$ of sources gave evidence of ICT4Ag strengthening household scale.

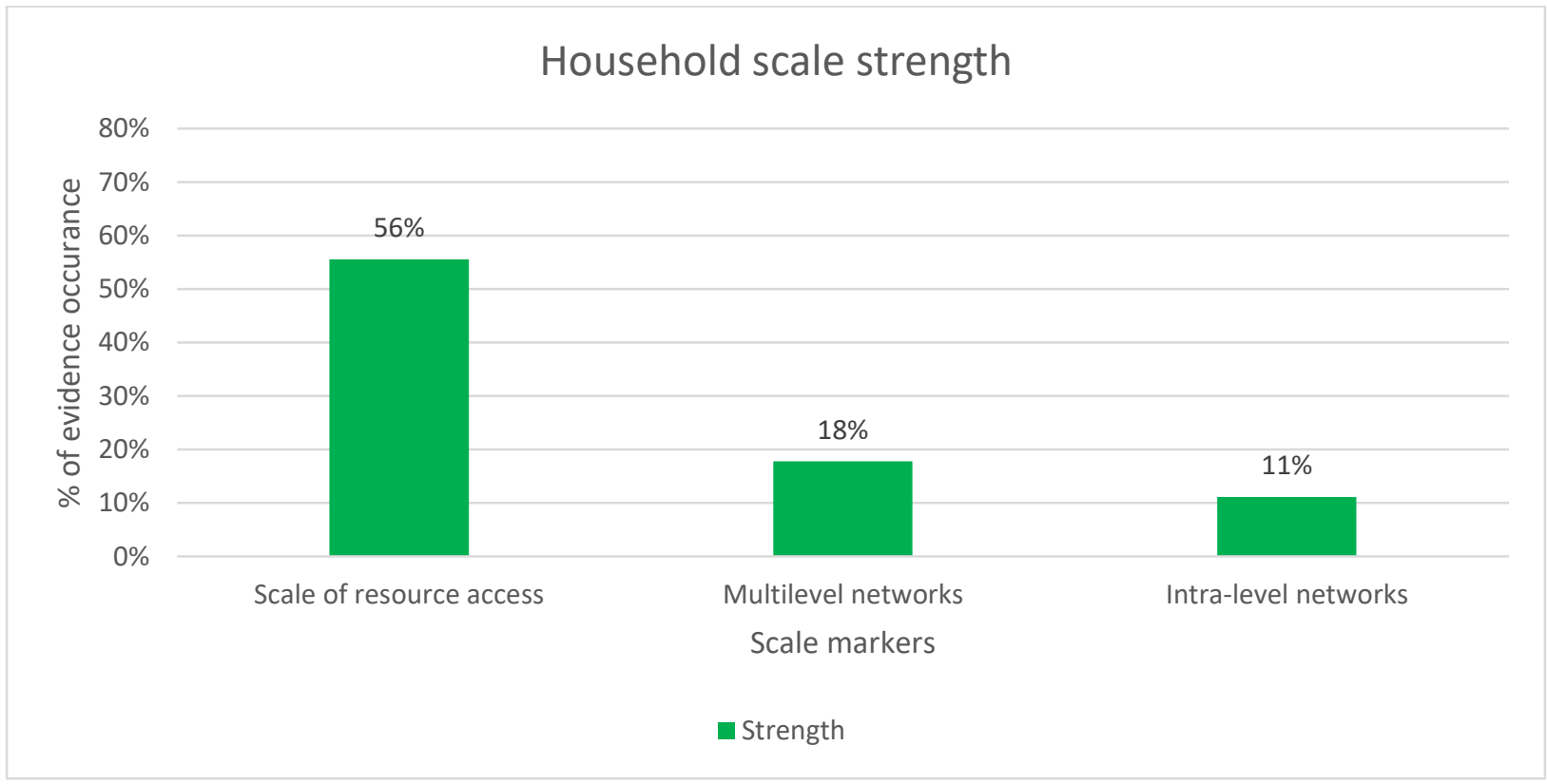

Figure C15: ICT4Ag household scale markers contribution 


\section{B. Community}

Regarding scale at community scope, $9 \%$ of sources (see Figure C16) reported evidence of ICTs facilitating scale of resource access, particularly by improving the flow of information and resources among community-level bodies during emergencies (e.g. livestock disease outbreak (Masuki et al., 2010), wildlife attacks (Lewis et al., 2016)), and by enabling community-level bodies (e.g. community radio (Lwoga, 2010)) to access agricultural knowledge/information from a diverse range of sources (e.g. internet, other international radio stations).

$7 \%$ of sources gave evidence of ICTs strengthening multi-level networks, particularly by facilitating the creation of networks between community-level bodies (e.g. farmer groups, village cooperation (Dannenberg \& Lakes, 2013; Lwoga, 2010)) and exporters/buyers who are outside the immediate community; thus, serving as alternative sources of markets.

There was only one source that reported evidence of ICTs contributing to intra-level networks, specifically by enabling the establishment of links between local community representatives and groups of farmers in remote areas (Mittal et al., 2010); thus, enabling community services to reach more people.

Overall, $16 \%$ of sources presented evidence of ICT4Ag strengthening community scale.

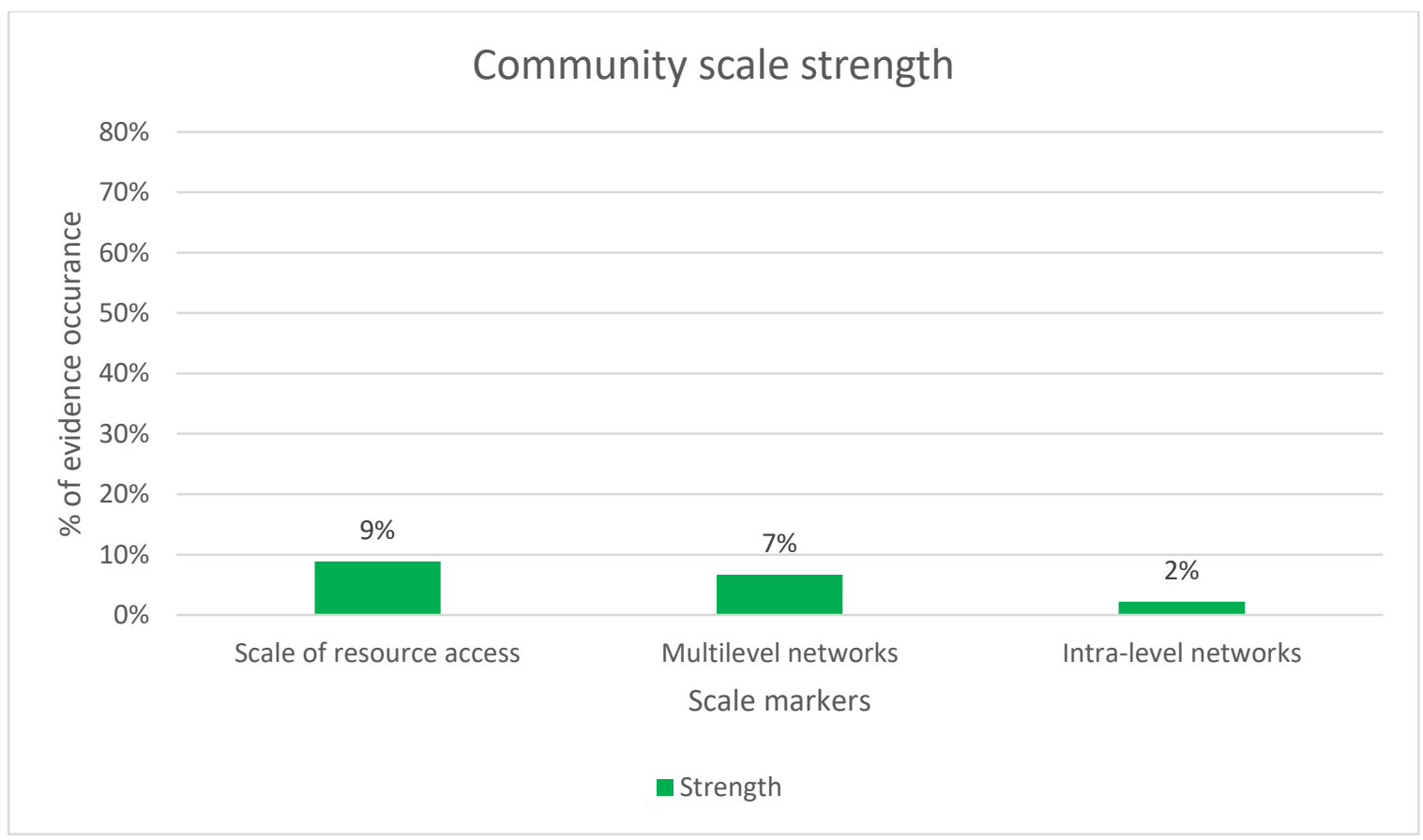

Figure C16: ICT4Ag community scale markers contribution 


\section{C2. ICT4Ag Weakening Resilience Attributes}

Having looked at the evidence of ICT4Ag strengthening resilience, this sub-section moves on to present findings of weakening. Overall, there was evidence of ICTs weakening resilience in seven out of the eight attributes (combining both household and community): there was no evidence of ICTs weakening rapidity. Out of those, five attributes had fewer than three sources giving evidence of weakness: scale, one source; learning, one source; selforganisation, one source; diversity \& flexibility, one source; and robustness, two sources. Evidence for these five attributes will not be presented further; evidence of the remaining two is presented below.

\section{C2.1 ICT4Ag and equality}

\section{A. Household}

Regarding equality at household level, two of the sources (see Figure C17) presented evidence of ICTs weakening inclusiveness and participation, primarily when reinforcing existing social structures, where men tend to have more access to ICTs, and gain more knowledge than women (Fu \& Akter, 2016; Piontak, 2012). Two other sources gave evidence of ICTs weakening equality of distribution of assets, particularly when it comes to ownership of ICTs (e.g. mobile phones), where a dramatic gap exists between men and women within households (Baardewijk, 2017). One of the sources gave evidence of ICTs weakening openness and accountability, specifically when used to facilitate lies and deception in social and agricultural activities (e.g. lies about the availability of water) and even infidelity within households (Baird \& Hartter, 2017). Overall, $11 \%$ of sources reported evidence of ICT4Ag weakening household equality.

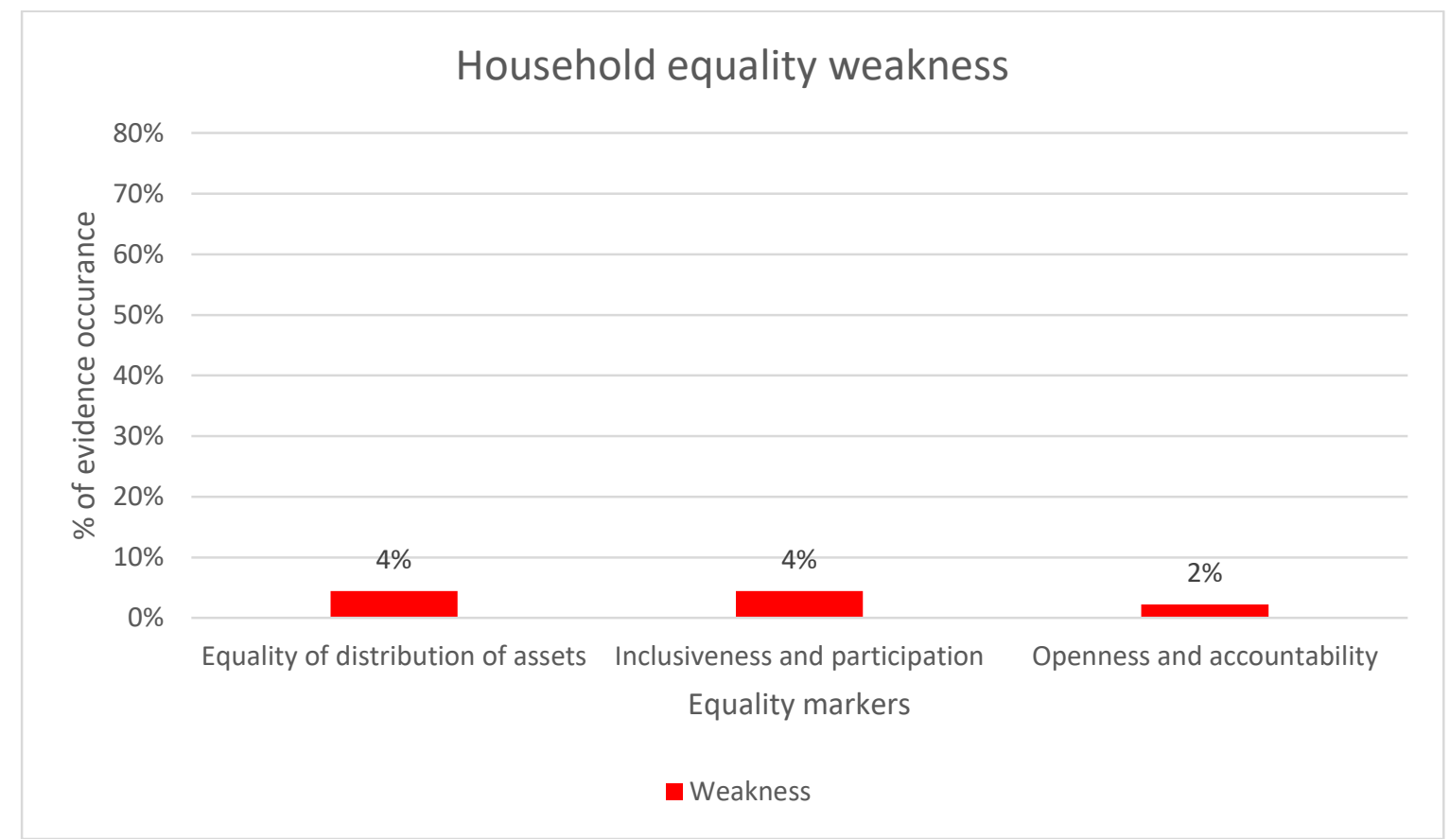

Figure C17: ICT4Ag household equality markers weakness contribution 
B. Community

$16 \%$ of sources (see Figure C18) provided evidence of ICTs weakening equality at community level, specifically inclusiveness and participation, as men, the rich, and the educated tended to use ICTs and benefit more than their counterparts. Related data shows that farmers who lack ownership and use of ICTs tend to be disconnected from the market; hence, further reducing their participation and bargaining position (Dannenberg \& Lakes, 2013; Krone et al., 2016).

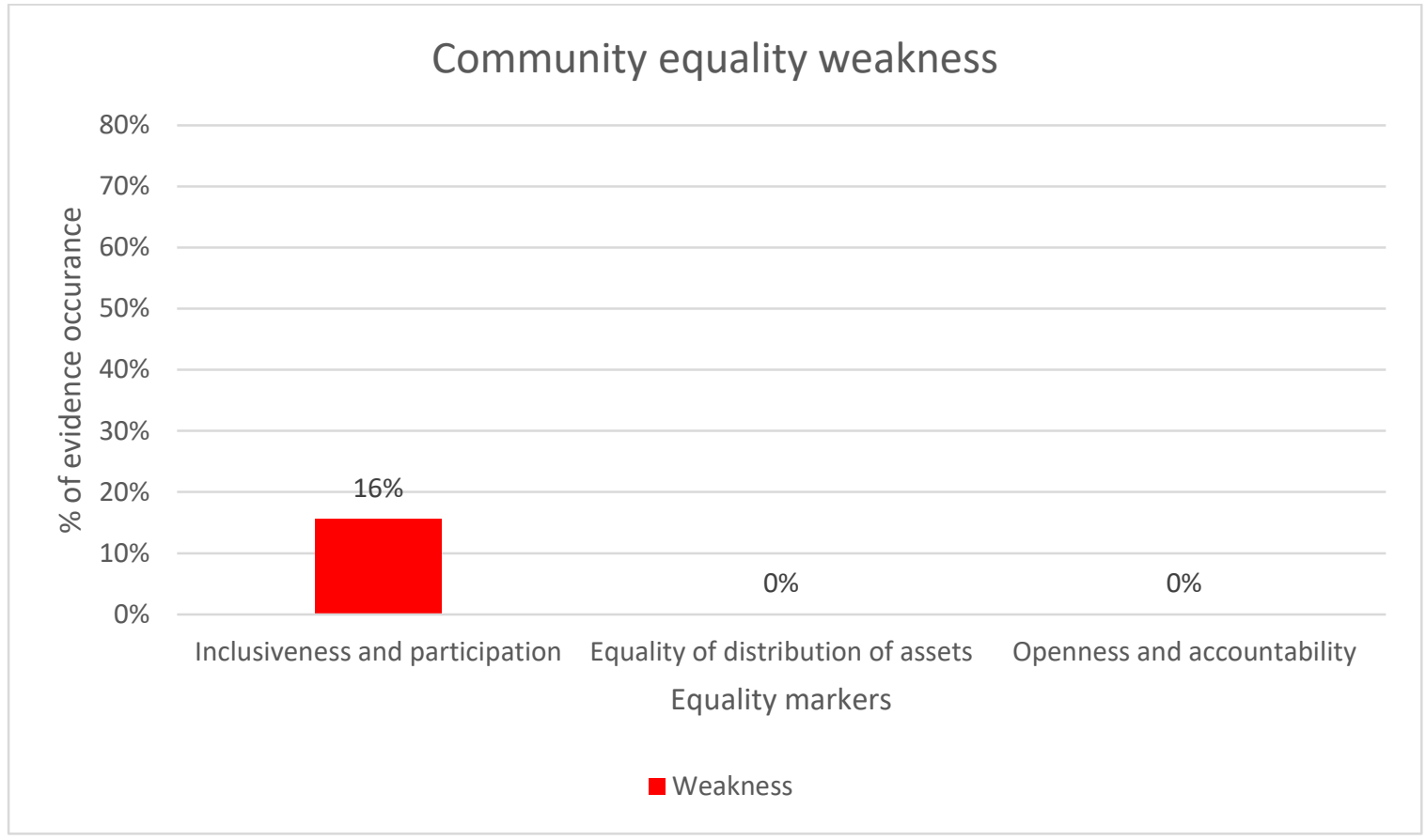

Figure C18: ICT4Ag community equality markers weakness contribution 


\section{C2.2 ICT4Ag and household redundancy}

Overall, $11 \%$ of sources (see Figure $\mathrm{C} 19$ ) reported evidence of ICTs weakening redundancy at household level, with all the evidence related to resource spareness, particularly because there is a cost implication associated with purchasing, using, and maintaining ICTs (e.g. purchasing mobile phone credit, charging mobile phones, repairing ICTs, etc.).

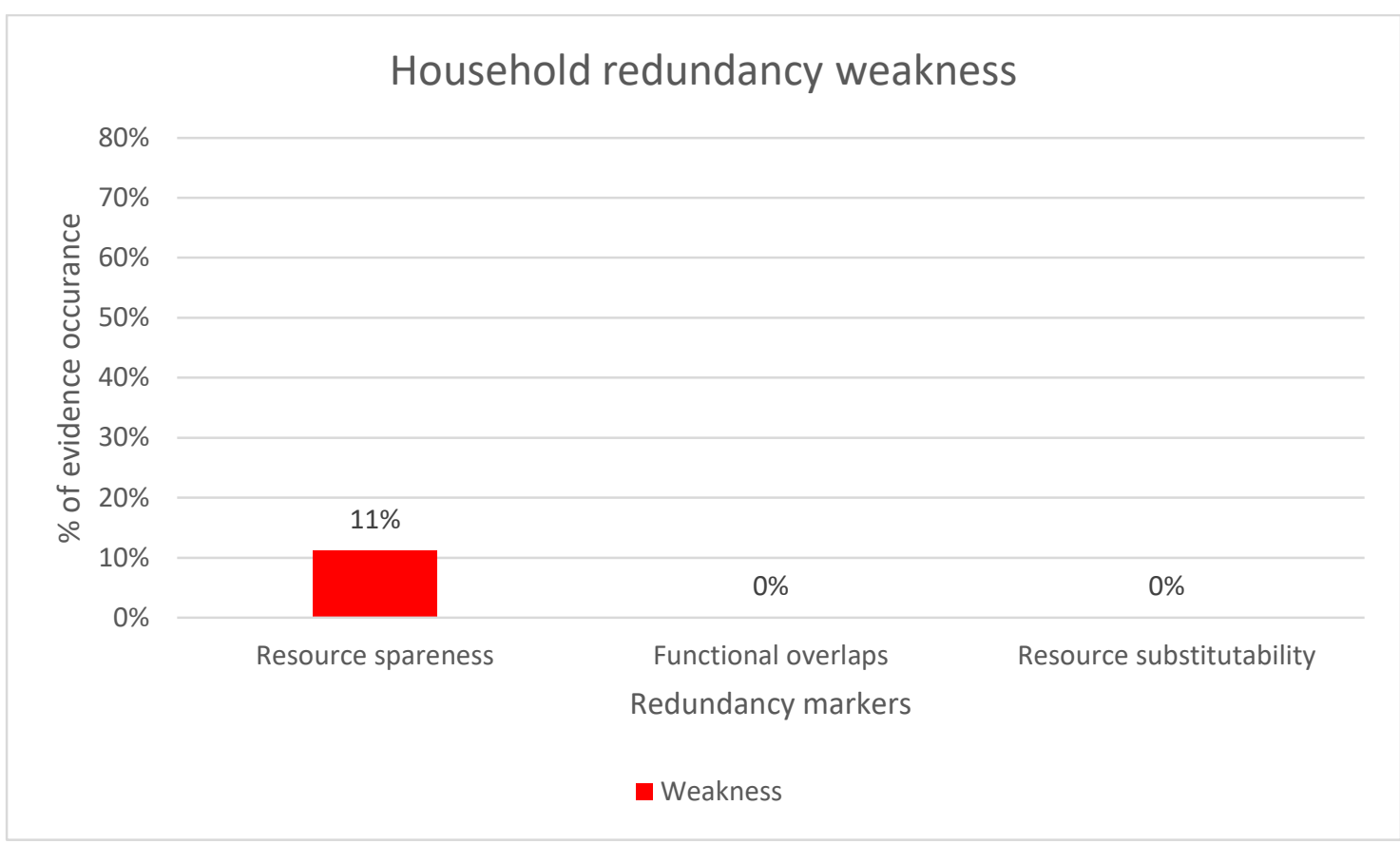

Figure C19: ICT4Ag household redundancy markers weakness contribution

\section{C3. Household and Community Resilience Attributes Summary}

This sub-section presents an overview of the findings for household, followed by community, and then a comparison between household and community scope.

\section{C3.1 Household resilience attributes summary}

In order to obtain an overall score of the contribution of ICT4Ag to each of the household resilience attributes, the proportion of unique sources that provided evidence of strength or weakness of at least one marker for each resilience attribute was used. This approach ${ }^{6}$ was taken because the markers in the RABIT framework are illustrative rather than comprehensive, and so this approach was seen as a good reflection of the extent to which ICT4Ag initiatives are impacting each of the resilience attributes. This approach is also less influenced by some of the operationalisation challenges encountered (see Sections E4 and E5), especially the categorisation of evidence among different markers of the same attribute.

\footnotetext{
${ }^{6}$ Alternative approaches were calculated based on different formulations - for example, individually averaging percentage of sources mentioning markers of an attribute, or excluding marker categories that were not evidenced from calculations - but they do not make much difference to the final shape of the findings.
} 
To get a resilience score for each attribute, first, the percentage of aggregate resilience scores for weakness and strength were computed, and then aggregate weakness was subtracted from aggregate strength to get the relative resilience attribute score as shown in Table C1 (see Appendix B for more details of each article).

Table C1: Household resilience attributes score summary

\begin{tabular}{|c|c|c|c|c|c|c|}
\hline $\begin{array}{l}\text { Resilience } \\
\text { attribute }\end{array}$ & Resilience markers & $\begin{array}{l}\% \\
\text { markers } \\
\text { weakness }\end{array}$ & $\begin{array}{l}\% \\
\text { markers } \\
\text { strength }\end{array}$ & $\begin{array}{l}\text { \% attribute } \\
\text { aggregate } \\
\text { weakness }\end{array}$ & $\begin{array}{l}\text { \% attribute } \\
\text { aggregate } \\
\text { strength }\end{array}$ & $\begin{array}{l}\text { Resilience } \\
\text { attribute } \\
\text { score }\end{array}$ \\
\hline \multirow{3}{*}{$\begin{array}{l}\text { Diversity \& } \\
\text { Flexibility }\end{array}$} & Adaptable decision-making & & $56 \%$ & & \multirow[b]{3}{*}{$71 \%$} & \multirow[b]{3}{*}{$71 \%$} \\
\hline & Innovation mechanism & & $9 \%$ & & & \\
\hline & Variety of courses of action & & $53 \%$ & & & \\
\hline \multirow{3}{*}{ Redundancy } & Functional overlaps & & $36 \%$ & \multirow[b]{3}{*}{$11 \%$} & \multirow[b]{3}{*}{$82 \%$} & \multirow[b]{3}{*}{$71 \%$} \\
\hline & Resource spareness & $11 \%$ & $73 \%$ & & & \\
\hline & Resource substitutability & & $20 \%$ & & & \\
\hline \multirow{3}{*}{ Learning } & Capacity building & & $18 \%$ & \multirow[b]{3}{*}{$2 \%$} & \multirow[b]{3}{*}{$69 \%$} & \multirow[b]{3}{*}{$67 \%$} \\
\hline & New and traditional knowledge & $2 \%$ & $62 \%$ & & & \\
\hline & Reflective thinking & & $2 \%$ & & & \\
\hline \multirow{3}{*}{ Scale } & Intra-level networks & & $11 \%$ & & \multirow[b]{3}{*}{$60 \%$} & \multirow[b]{3}{*}{$60 \%$} \\
\hline & Multi-level networks & & $18 \%$ & & & \\
\hline & Scale of resource access & & $56 \%$ & & & \\
\hline \multirow{3}{*}{ Rapidity } & Rapid issue assessment & & $4 \%$ & & \multirow[b]{3}{*}{$58 \%$} & \multirow[b]{3}{*}{$58 \%$} \\
\hline & Rapid issue detection & & $36 \%$ & & & \\
\hline & Rapid issue response & & $47 \%$ & & & \\
\hline \multirow{3}{*}{ Robustness } & Institutional capacity & & $33 \%$ & & \multirow[b]{3}{*}{$53 \%$} & \multirow[b]{3}{*}{$53 \%$} \\
\hline & Loose functional coupling & & $4 \%$ & & & \\
\hline & Physical preparedness & & $22 \%$ & & & \\
\hline \multirow{3}{*}{$\begin{array}{c}\text { Self- } \\
\text { Organisation }\end{array}$} & $\begin{array}{l}\text { Collaboration and consensus- } \\
\text { building }\end{array}$ & & $4 \%$ & \multirow[b]{3}{*}{$2 \%$} & \multirow[b]{3}{*}{$27 \%$} & \multirow[b]{3}{*}{$24 \%$} \\
\hline & Local leadership & & $7 \%$ & & & \\
\hline & Social networks and trust & $2 \%$ & $22 \%$ & & & \\
\hline \multirow{3}{*}{ Equality } & Equality of distribution of assets & $4 \%$ & $2 \%$ & \multirow[b]{3}{*}{$11 \%$} & \multirow[b]{3}{*}{$36 \%$} & \multirow[b]{3}{*}{$24 \%$} \\
\hline & Inclusiveness and participation & $4 \%$ & $36 \%$ & & & \\
\hline & Openness and accountability & $2 \%$ & & & & \\
\hline
\end{tabular}

Based on Table C1 (see also Figure C20), at the household level, the evidence on use of ICTsin-agriculture suggests three categories of resilience impact, whether considering just strengthening, or a combined score that integrates both strengthening and weakening. Three attributes - household redundancy, diversity \& flexibility, and learning - are strengthened most. Three attributes - household scale, rapidity and robustness - are strengthened somewhat. Two attributes - household self-organisation and equality - are not evidenced as being strengthened very much.

The literature evidence base on ICT4Ag initiatives suggests only a small impact in weakening household resilience; reflected most in terms of household equality and redundancy, and 
very slightly in relation to self-organisation and learning. However, overall, the reported evidence suggests that ICT4Ag interventions are strengthening the resilience attributes of rural households far more than weakening them.

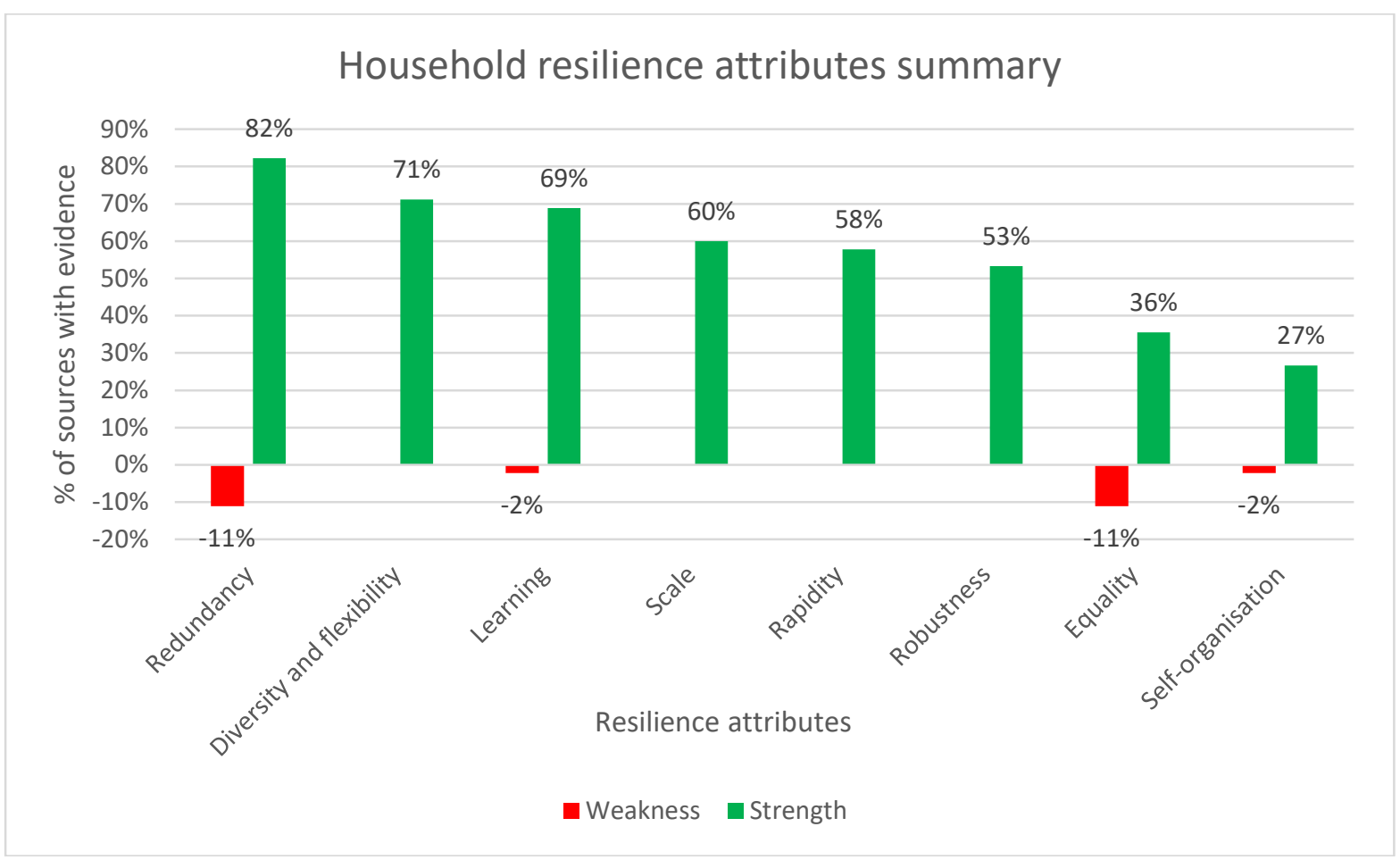

Figure C20: ICT4Ag household resilience attributes summary 


\section{C3.2 Community resilience attributes summary}

The computation of community-level resilience attribute scores took a similar approach to that for household-level resilience attributes scores, as summarised in Table C2.

\section{Table C2: Community resilience attributes score summary}

\begin{tabular}{|c|c|c|c|c|c|c|}
\hline $\begin{array}{l}\text { Resilience } \\
\text { attribute }\end{array}$ & Resilience markers & $\begin{array}{l}\% \\
\text { markers } \\
\text { weakness }\end{array}$ & $\begin{array}{l}\% \\
\text { markers } \\
\text { strength }\end{array}$ & $\begin{array}{l}\% \text { attribute } \\
\text { aggregate } \\
\text { weakness }\end{array}$ & $\begin{array}{l}\% \text { attribute } \\
\text { aggregate } \\
\text { strength }\end{array}$ & $\begin{array}{l}\text { Resilience } \\
\text { attribute } \\
\text { score }\end{array}$ \\
\hline \multirow{3}{*}{$\begin{array}{c}\text { Self- } \\
\text { Organisation }\end{array}$} & $\begin{array}{l}\text { Collaboration and consensus- } \\
\text { building }\end{array}$ & $2 \%$ & $18 \%$ & \multirow[b]{3}{*}{$2 \%$} & \multirow[b]{3}{*}{$38 \%$} & \multirow[b]{3}{*}{$36 \%$} \\
\hline & Local leadership & & $13 \%$ & & & \\
\hline & Social networks and trust & & $20 \%$ & & & \\
\hline \multirow[b]{3}{*}{ Redundancy } & Functional overlaps & & $9 \%$ & & \multirow[b]{3}{*}{$13 \%$} & \multirow[b]{3}{*}{$13 \%$} \\
\hline & Resource spareness & & $4 \%$ & & & \\
\hline & Resource substitutability & & $2 \%$ & & & \\
\hline \multirow[b]{3}{*}{ Scale } & Intra-level networks & & $2 \%$ & \multirow[b]{3}{*}{$2 \%$} & \multirow[b]{3}{*}{$16 \%$} & \multirow[b]{3}{*}{$13 \%$} \\
\hline & Multi-level networks & & $7 \%$ & & & \\
\hline & Scale of resource access & $2 \%$ & $9 \%$ & & & \\
\hline \multirow[b]{3}{*}{ Learning } & Capacity building & & $2 \%$ & & \multirow[b]{3}{*}{$11 \%$} & \multirow[b]{3}{*}{$11 \%$} \\
\hline & New and traditional knowledge & & $11 \%$ & & & \\
\hline & Reflective thinking & & & & & \\
\hline \multirow[b]{3}{*}{ Rapidity } & Rapid issue assessment & & & & \multirow[b]{3}{*}{$9 \%$} & \multirow[b]{3}{*}{$9 \%$} \\
\hline & Rapid issue detection & & $2 \%$ & & & \\
\hline & Rapid issue response & & $7 \%$ & & & \\
\hline \multirow{3}{*}{$\begin{array}{l}\text { Diversity \& } \\
\text { Flexibility }\end{array}$} & Adaptable decision-making & & $4 \%$ & \multirow[b]{3}{*}{$2 \%$} & \multirow[b]{3}{*}{$7 \%$} & \multirow[b]{3}{*}{$4 \%$} \\
\hline & Innovation mechanism & & & & & \\
\hline & Variety of courses of action & $2 \%$ & $4 \%$ & & & \\
\hline \multirow[b]{3}{*}{ Robustness } & Institutional capacity & $4 \%$ & $9 \%$ & \multirow[b]{3}{*}{$4 \%$} & \multirow[b]{3}{*}{$9 \%$} & \multirow[b]{3}{*}{$4 \%$} \\
\hline & Loose functional coupling & & & & & \\
\hline & Physical preparedness & & & & & \\
\hline \multirow[b]{3}{*}{ Equality } & Equality of distribution of assets & & $2 \%$ & \multirow[b]{3}{*}{$16 \%$} & \multirow[b]{3}{*}{$16 \%$} & \multirow[b]{3}{*}{$0 \%$} \\
\hline & Inclusiveness and participation & $16 \%$ & $11 \%$ & & & \\
\hline & Openness and accountability & & $2 \%$ & & & \\
\hline
\end{tabular}

On aggregate, looking at Table C2 (see also Figure C21), the literature evidence suggests the resilience impact of ICTs-in-agriculture is towards community self-organisation far more than any other attribute. The much smaller prevalence of community-level evidence compared to household-level evidence means a greater difference between integrated and strengthening-only scores. One might separate out a slightly greater resilience impact on community redundancy, scale, learning and equality; and a slightly lesser resilience impact on community rapidity, diversity \& flexibility, and robustness. But the differences between these seven is too small to draw any strong conclusions.

Similarly, in relation to the weakening of community resilience by ICTs-in-agriculture appears somewhat in relation to equality. Evidence of weakening of the other four 
identified attributes - robustness, self-organisation, scale, and diversity \& flexibility - is so limited as to be barely worthy of note; relying as it does on the evidence of just one or at most two sources. Overall, bar equality, our re-analysis of published research suggests ICT4Ag interventions strengthen community resilience attributes more than weakening them.

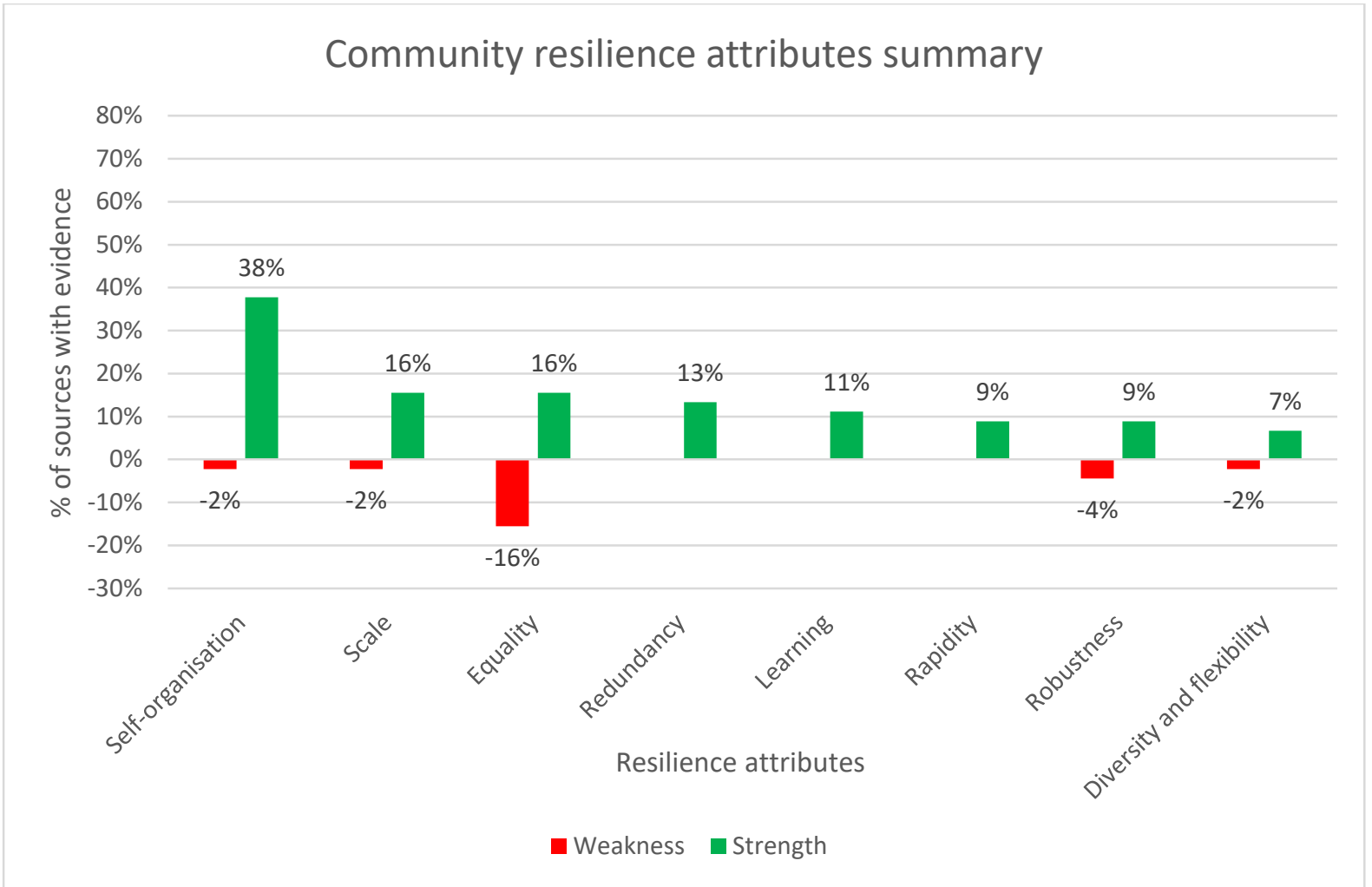

Figure C21: ICT4Ag community resilience attributes summary 


\section{C3.3 Comparison of community and household resilience attributes summary}

Looking at the attribute aggregate strength columns in Table $\mathrm{C} 1$ and Table $\mathrm{C} 2$, there is much more reported evidence of ICT4Ag strengthening household resilience attributes than community resilience attributes, save only for the self-organisation attribute (see Figure $\mathrm{C} 22$ ). As can be seen from Figure C22, there is no overlap between the leading strengthened household resilience attributes - redundancy, diversity \& flexibility, and learning; and the leading strengthened community resilience attribute - self-organisation, with scale and equality some way behind. Overall, there is little to clearly differentiate the foundational resilience attributes (robustness, self-organisation, learning) from the other, enabling attributes.

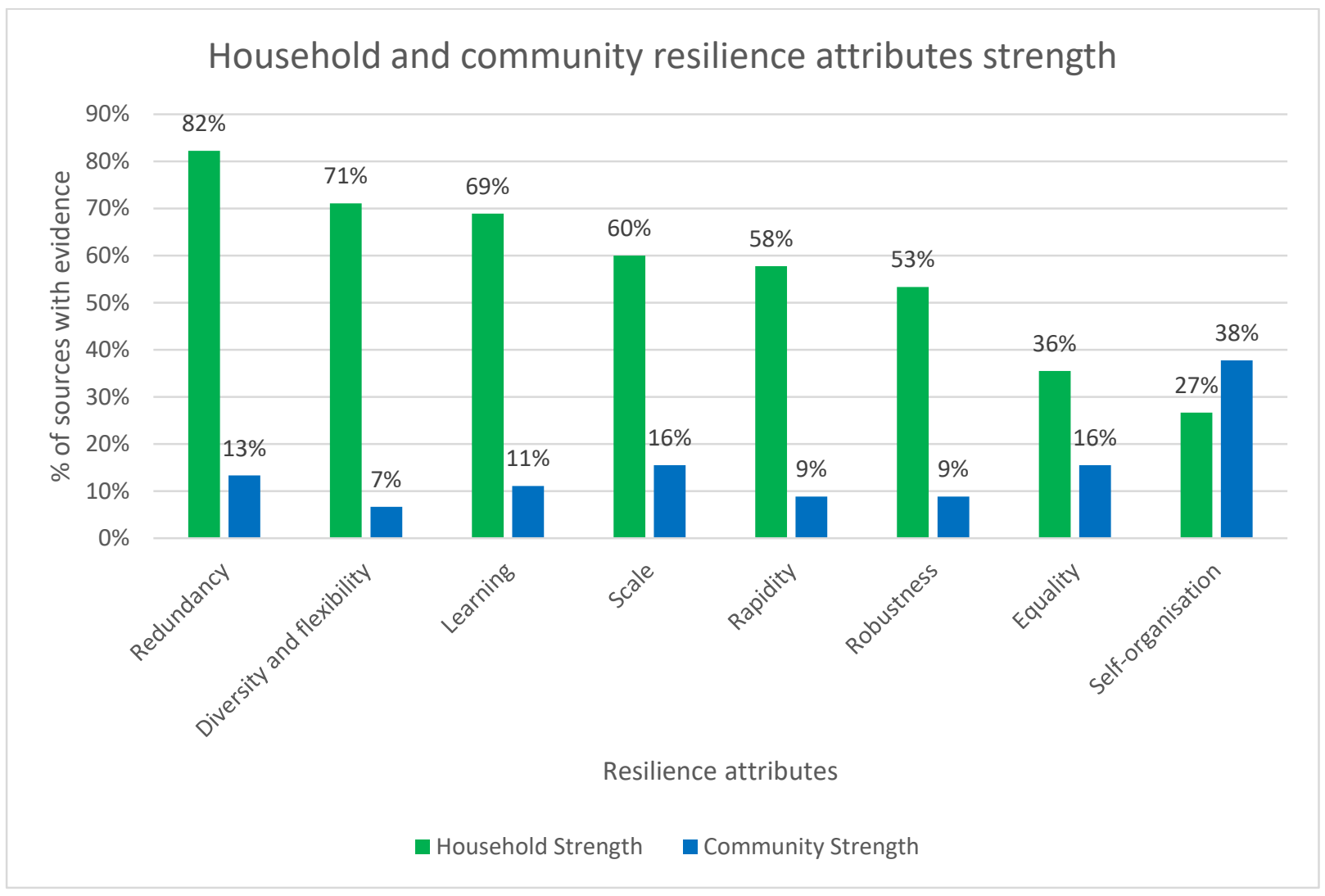

Figure C22: Household and community resilience attributes strength comparison

Findings on resilience weakening are much more limited (see Figure C23). There is only any real evidence base of ICTs-in-agriculture weakening equality, with some evidence of household redundancy being weakened. Other attributes are mentioned, some for households, some for community but as noted above, the evidence base is so small that one cannot really draw conclusions. 


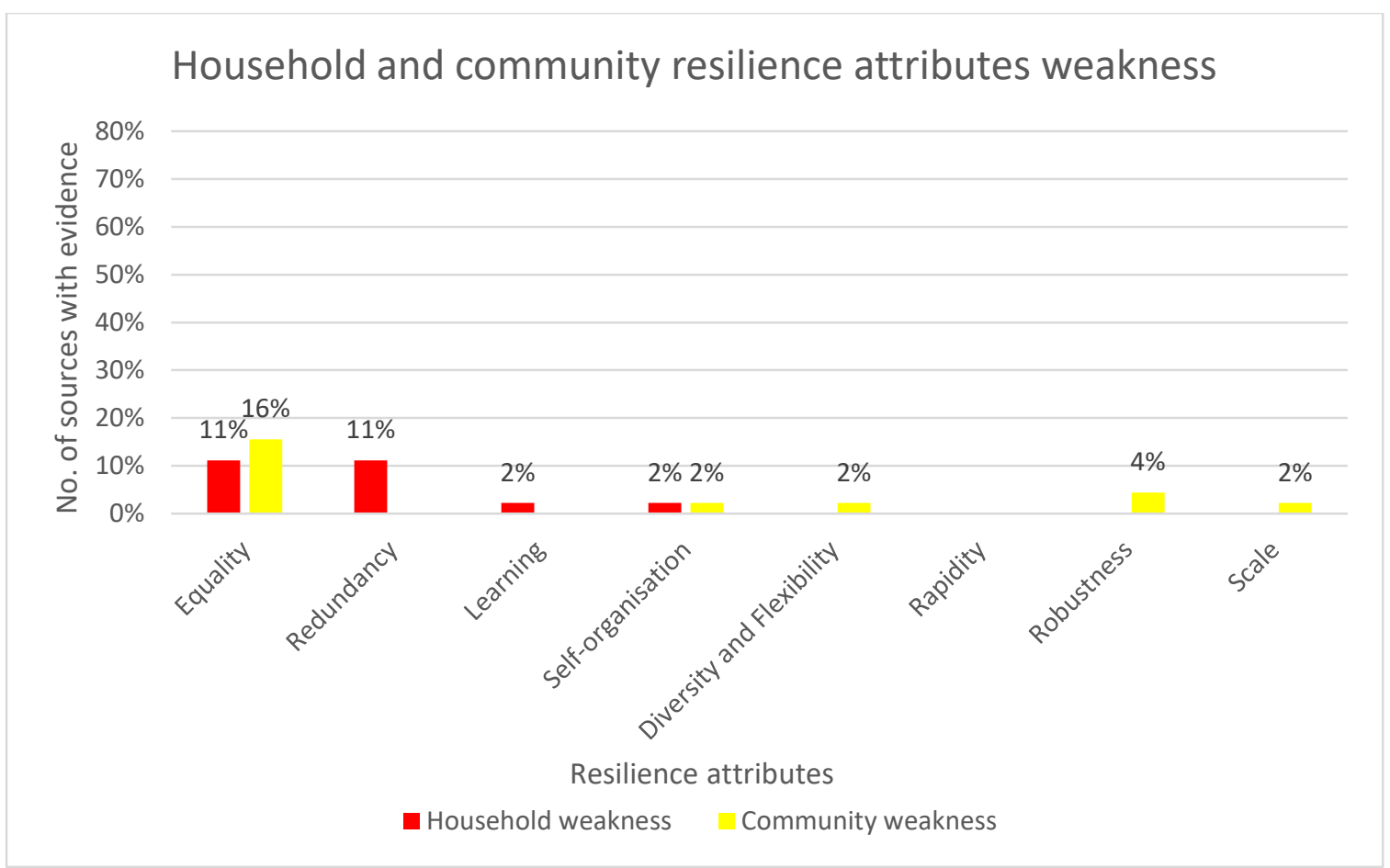

Figure C23: Household and community resilience attributes weakness comparison 


\section{Analysis: Explaining ICTs' Impact on Rural Resilience}

Addressing the second research objective, this section provides further analysis and discussion of the findings with a new inductive conceptualisation to summarise why the observed resilience impacts are seen.

\section{D1. ICT4Ag and Resilience of Rural Households}

As argued in Section C3.1, the reported evidence suggests three levels of contribution that ICT4Ag makes to rural household resilience: a relatively low contribution to self-organisation and equality; a medium-high contribution to scale, rapidity and robustness; and a high contribution to redundancy, diversity \& flexibility, and learning. Each will be discussed in turn.

\section{D1.1 Relatively Low ICT4Ag Contribution: Self-Organisation and Equality}

One possible explanation for the low contribution of ICT4Ag initiatives to household selforganisation and equality is the design and implementation of ICT4Ag projects, where relatively little focus has been given to these development outcomes (Heeks, 2014b; Walsham, 2017). For example, in only three (Manfre \& Nordehn, 2013; Mittal, 2015; Sekabira \& Qaim, 2017b) out of the 45 sources, was there a central theme for ICTs-inagriculture initiatives around equality and empowerment, and none on self-organisation.

Another possibility is the difficulty in strengthening these attributes, mainly because they often require associated parallel changes, such as changes in social and power structures, institutions, and resources (Ali \& Kumar, 2011; Fu \& Akter, 2016; Mittal, 2015). Yet ICTs' adoption, use and impact tend to be shaped by the existing institutions and structural relations, rather than the opposite (Heeks, 2018; Zheng et al., 2018). We saw this most strongly in relation to equality. There were positive signs that ICT4Ag can contribute to equality, particularly on the "inclusiveness and participation" marker, with marginalised households and members (e.g. women) having benefitted despite being late adopters (Kikulwe et al., 2014; Martin \& Abbott, 2011). However, the structural - particularly gender - inequalities that are dominant in rural areas of many developing countries, and the tendency for reproduction of social structures during technological change make it hard for ICTs to make a difference (Kanbur \& Venables, 2005). Hence, evidence of ICT4Ag weakening equality: reproducing and even reinforcing inequalities within households, as men tend to own, use, and benefit more from ICTs than women (Baardewijk, 2017; Fu \& Akter, 2016; Loudon, 2016).

Regarding self-organisation, the evidence suggests that ICTs' contribution towards maintaining the social networks, trust or collaborative decision-making of household members occurs when those household members are in different geographical locations (Matuha, 2015; Salia et al., 2011; Shaffril et al., 2015). But, for most rural households, faceto-face interactions will be by far the dominant means of interaction and of selforganisation, in which case ICTs have little role to play (Baird \& Hartter, 2017; Molony, 2006; 2008). ICTs' intra-household role will also be limited because, at least until recently, ownership was typically limited to one device per household. 


\section{D1.2 Medium-High ICT4Ag Contribution: Scale, Rapidity, and Robustness}

For these attributes, there is some evidence of ICT4Ag initiatives making improvements where interventions have focused on improving access to markets (e.g. Ajwang, 2014; Baumüller, 2015), and provision of climatic information (e.g. Baardewijk, 2017; Cole \& Fernando, 2012), among others. These improvements have tended to emerge from the expressed affordances of ICT - rapid processing and communication of data, faster and broader social interaction (Heeks, 2018). These affordances, based on the technologies' inherent functionalities, tend to necessarily improve rapidity and scale.

Of the three attributes, strengthening of robustness was seen least. This may relate to the requirement for complementary resources in order to turn data into resilience impacts. Such complementarities are least-required for mobile phones when used as simple communication devices (Mtega \& Msungu, 2013; Mwantimwa, 2019; Sife et al., 2010). But this communicative simplicity has rather limited the impact of these devices on robustness (to some extent strengthening institutional capacities and physical preparedness) (Mittal \& Tripathi, 2009; Ogunniyi \& Ojebuyi, 2016; Shaffril et al., 2015). More complex ICTs - such as geographic information systems (GIS) and remote sensing technologies for monitoring climate events and related shocks and trends - are crucial for building robustness; physical preparedness especially (Belal et al., 2014; World Bank, 2014; Zhao et al., 2005). However, such ICTs require a substantial level of skills, knowledge, technical infrastructure, money, etc.: resources that are typically in short supply in developing countries, especially in rural areas (Heeks, 2018).

Even within households, the need for complementary resources may act as a brake on resilience impacts. For example, the level of education of households was reported to impact the scale and rapidity benefits obtained from ICT4Ag: in other words, lack of knowledge and skills constraining the realisation of ICT functionalities into resiliencerelevant affordances (Ali \& Kumar, 2011; Krone et al., 2016).

Finally, institutional and structural factors constrain the potential impact of ICTs. Provision of ICT-enabled market and climatic information can strengthen these resilience attributes. But traditional sources and channels of information sustain even in the face of ICTs (Duncombe, 2006). They do this because of cultural norms and because trust and social relations (see above) remain heavily invested in traditional information channels (Ajwang, 2014; Baumüller, 2015; Gyan, 2018; Mwakaje, 2010).

\section{D1.3 High ICT4Ag Contribution: Learning, Redundancy, and Diversity \& Flexibility}

One reason these three attributes have been particularly strengthened by ICT4Ag is that interventions are designed to target these attributes. For example, various initiatives (e.g. Baardewijk, 2017; Cole \& Fernando, 2012; Fu \& Akter, 2016; Krone et al., 2016) have focused on building agricultural and/or climatic knowledge, thus improving learning. Financial issues are a part of many ICT4Ag initiatives whether reducing expenditure via the digital affordance of journey substitution or increasing income by improving farm productivity, market access, remittance access, or access to mobile money (Baumüller, 2015; Gyan, 2018; Kikulwe et al., 2014). All of these have addressed the resource spareness element of redundancy. 
In the design of many ICT4Ag initiatives, ICTs tend to complement existing services/resources rather than substituting them (Duncombe, 2006); hence tending to increase the diversity of sub-systems and channels available to rural households. ICTs' multi-functionality also tends to inherently provide flexibility for users.

The perceived utility (beliefs and motivations) about particular attributes may also have an influence here. The realities of climate change - needs for both short-term coping and longer-term adaptation - have created an impetus for rural households; particularly in relation to wanting to acquire new knowledge (learning) and to diversify from or within agricultural activities (diversity \& flexibility) (Heeks \& Ospina, 2012). This expressed utility will both influence ICT4Ag project priorities and designs, and shape the way in which rural users employ the technologies provided. Hence, the relatively high incidence of benefits related to these attributes (e.g. Fu \& Akter, 2016; Martin \& Abbott, 2011; Mittal, 2015).

Another likely explanation is that ICT4Ag initiatives affecting these attributes have mostly supported existing activities, thus requiring fewer complementary changes (Baird \& Hartter, 2017; Dannenberg \& Lakes, 2013). For example, through supporting diversification of crops already existing in an area, rather than trying to introduce new ones (Baumüller, 2015); supporting mobilisation of existing agricultural inputs (Furuholt \& Matotay, 2011); supporting market access flexibility by linking to existing local markets (Salia et al., 2011); and journey substitutions (Sife et al., 2010). ICTs thus have strengthened redundancy, and diversity \& flexibility with few or even no institutional or structural relations changes required.

\section{D2. ICT4Ag and Resilience of Rural Communities}

As evidenced in Section C3.2, ICT4Ag makes a medium contribution to self-organisation and a low contribution to all other attributes.

\section{D2.1 Medium ICT4Ag Contribution: Self-Organisation}

Self-organisation has been the leading resilience attribute strengthened by ICTs-inagriculture in part because of deliberate ICT4Ag initiative designs to establish linkages/networks within communities. Self-organisation has been a long-standing and well-established approach to agricultural and rural development. For example, creating farmer groups is shown to help farmers increase their bargaining position, improve access to markets, and reduce their operational costs (Dannenberg \& Lakes, 2013; Furuholt \& Matotay, 2011; Masuki et al., 2010). More generally, group formation is widely-used to foster social learning and local knowledge, and activate safety nets and existing capabilities (Berkes \& Ross, 2013; Scott, 2013).

Thus it is not surprising that ICT4Ag initiatives would prioritise this. Some notable examples include mobile phone-based applications, such as M-Farm and Esoko (Arinloye et al., 2015; Baumüller, 2015; Gyan, 2018), which have enabled the formation of contract-based linkages between groups of farmers and traders. Alongside these new formations, ICT4Ag has worked "with the grain" of social structures given the existing strength of social capital and of community-level institutions within rural communities (High et al., 2005; Pretty, 2003). ICTs support these structures, particularly improving their collaboration and consensusbuilding activities (Duncombe, 2014). 


\section{D2.2 Low ICT4Ag Contribution: Other Attributes}

The limited evidence of ICTs contributing to other attributes of community resilience reflects a relative lack of ICT4Ag practice and/or research at the community level other than in relation to self-organisation (Duncombe, 2016). Notwithstanding some support for community self-organisation, the greater focus of interventions has been on individual farmers and households. Our findings may also reflect the research process: out of the 45 research papers, only four involved community-level body members during data collection. This may have limited the extent of evidence gathered that would be relevant to community-level resilience.

\section{D3. Conceptualising ICT4Ag and Resilience}

Based on the summary of findings just presented, and integrating and adapting two existing ICT-for-development models (Heeks, 2018; Heeks \& Shekhar, 2019a), we can produce a conceptual model that captures the findings (see Figure D1). Key features of the model are:

- A differentiation between wider livelihood system and the ICT4Ag digital system.

- The working of any ICT4Ag system is driven by perceived utility - the beliefs and motivations of users - combined with the functionalities offered by the digital technology involved. The former was reflected, for example, in the motivation of rural households to gain new knowledge to cope with climate change. Utility and digital functionality combine to create the realised affordances of the digital system expressed, for example, as data processing, communication and social interaction affordances.

- The core working of any ICT4Ag system is an information value chain that processes data into information, which feeds decisions, actions and then results in terms of the impacts on the systemic resilience attributes that have been described in detail above.

- These value chain processes require a set of resources in order to function effectively. As indicated in the diagram, these include knowledge and both "soft" and "hard" other resources. This was seen above hindering the diffusion and resilience impact of more complex ICTs which required resources scarce in rural areas: skills, knowledge, technical infrastructure, money, etc.

- The ICT4Ag system processes including its resilience impacts will be shaped by wider systemic factors. Not just the utility and digital functionalities already mentioned but also social factors including local institutions, resource access/control, and social structures. This was seen, for example, in the reproduction and even reinforcement of gender inequalities by ICTs. However, these wider factors are also themselves shaped by the ICT4Ag system: seen, for example, where ICTs supported the social inclusion of marginalised actors.

This model relates to the earlier livelihoods-based model (see Figure B3) - for example, incorporating the livelihood determinants and actions, the ICTs, and the resilience properties of the livelihood system. But it gives more emphasis to the workings of the ICT system and less emphasis to the wider vulnerability context (this could readily be added as a wider concentric ring but was omitted here for the sake of simplicity).

Built inductively from the findings, this model can now be used in future for deductive analysis of the resilience impacts of ICT4Ag, and the factors affecting those impacts. 


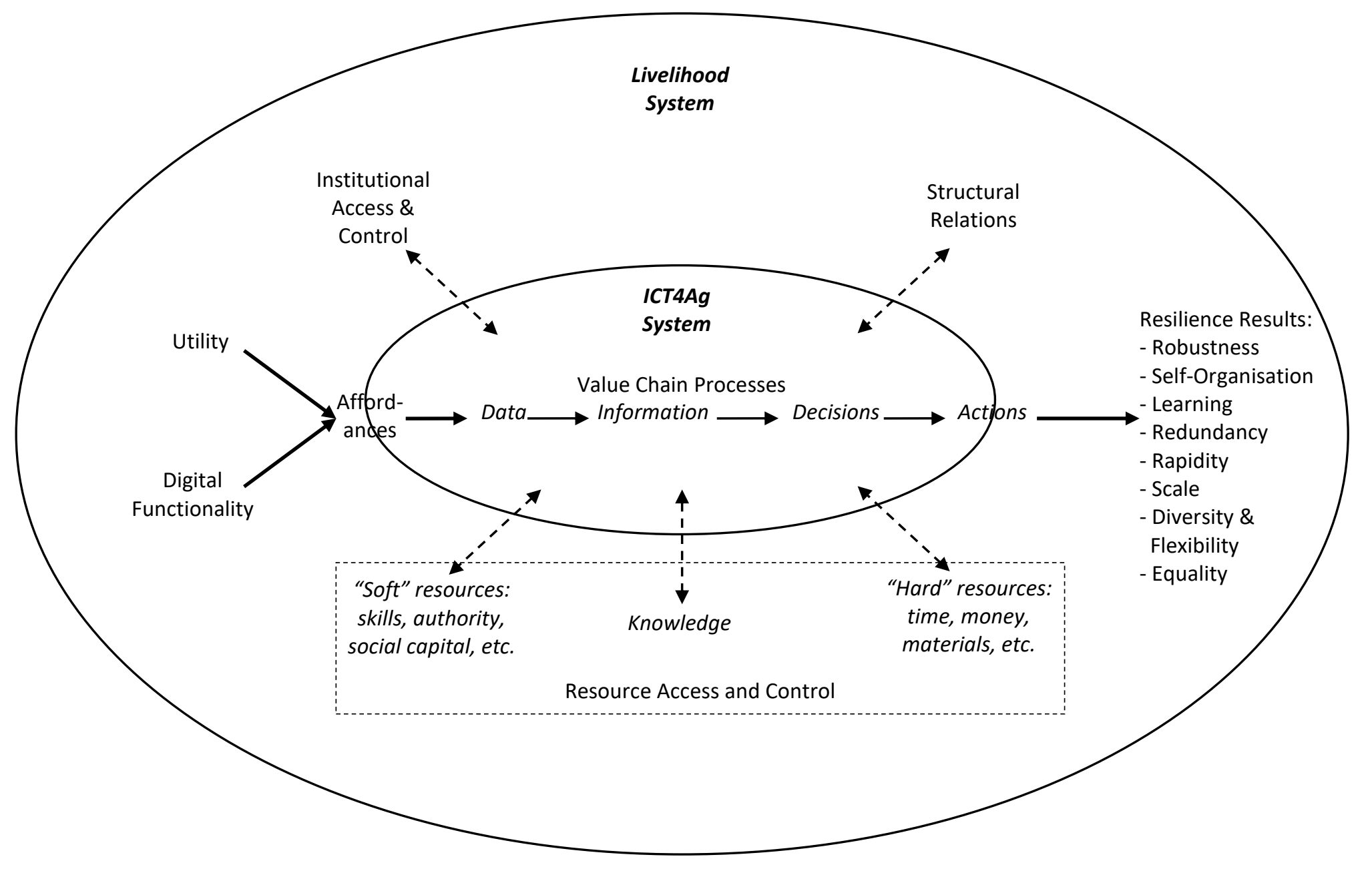

Figure D1: ICT4Ag and resilience model 


\section{E. Conclusions and Recommendations}

This final section will revisit the research question, and attempt to link the findings to the broader trends in the literature. It then addresses the final two research objectives by making recommendations for resilience practice and policy; by critically reflecting on the RABIT framework in relation to strengths, challenges, and potential revisions; and by proposing a future research agenda.

\section{E1. Revisiting the Research Question}

To what extent is the use of ICTs-in-agriculture weakening or strengthening the resilience of rural households and communities in developing countries, and why?

Considering the evidence presented earlier, two conclusions can be suggested; first, overall the use of ICTs-in-agriculture appears to be strengthening the resilience of rural households and communities in developing countries much more than it is weakening it; and secondly, ICT4Ag initiatives seem to attend to the resilience of households more than that of communities.

Regarding the first conclusion, although the overall trend is for strengthening resilience, the impact analysed from the literature was differentiated between resilience attributes. The most-strengthened attributes - redundancy, diversity \& flexibility, learning at household level; self-organisation at community level - were associated with: specific targeting by ICT4Ag initiatives compared to other attributes; the need for relatively fewer parallel changes (of resources, institutions, and structural relations of power); and the presence of individual-level drivers in the form of perceived utility of ICT4Ag impact on these particular attributes. On the other hand, less- and least-strengthened attributes were associated with less focus of ICT4Ag initiatives; greater need for complementary resources and other changes in order to achieve results; lower reports of individual motivation; and more evidence of weakening resilience alongside strengthening. The link between resilience and the functionalities and expressed affordances of ICTs was also stronger with more-strengthened attributes.

These findings formed the basis for creation of a new ICT4Ag and resilience model, bringing together key findings about the importance of perceived utility, digital functionality and affordances, the information value chain, the role of complementary resources, and the influence of wider systemic factors such as institutions and structural relations. This echoes and reinforces similar messages found in the ICTs-for-development (ICT4D) literature (Heeks, 2010; 2018; Murphy \& Carmody, 2015; Pieterse, 2010; Zheng et al., 2018).

Although relatively limited evidence emerged from the literature about weakening of resilience, it remains a live concern; especially in relation to the costs of ICTs and the potential for augmentation of existing inequalities. In turn, this both echoes and reinforces the growing literature on "digital harms"; harms which need to be identified and addressed as much as possible within project design (Heeks, 2016; Walsham, 2017; Wyche et al., 2016). 
The second conclusion - ICTs being linked to household resilience more than community-level resilience - may reflect the growing individualisation of ICT4D (Duncombe, 2016; Heeks, 2016). As noted earlier, ICT innovations have propelled this but it may also be driven by changing conceptualisations of development with, for example the growing use of Amartya Sen's (1999) ideas being linked to a more individualised model of development (Heeks, 2018; Zheng et al., 2018).

In sum, therefore, it is suggested that ICTs are building the resilience and adaptive capacities of rural households and communities in developing countries, particularly through elimination of agricultural and market-related "information failures" - absence, quality, uncertainty, asymmetry, costs (Heeks \& Molla, 2009) - that undermine learning; through linkages and network formation that not only reinforce or build social structure but also provide greater resource access; and by enabling a diversity of courses of action to support existing activities, among others, thus improving agricultural production and reducing market-related challenges. However, so far, the contribution has been small and incremental, one that is still insufficient to deliver the long-term resilience of rural households and communities in developing countries.

\section{E2. Recommendations for Practice}

Having summarised the reported contribution of ICTs to the resilience of households and communities, this sub-section analyses implications for practice.

ICT4Ag seems to impact household resilience significantly more than community resilience. This argument and the overall resilience results may reflect how ICT4Ag cases are researched and written, but likely also reflects the reality that ICT4Ag focuses much more at the level of individual farmers and households than on engaging with, and strengthening, whole communities. This, in turn, reflects two elements indicated in the Figure D1 model. First, that the potential functionalities and realised affordances of ICTs are increasingly associated with the individual rather than the community (Heeks, 2016), with some evidence (e.g. Lee \& Bellemare, 2013; Lwasa et al., 2011; Masuki et al., 2010) that this is leading to a general lack of awareness of and participation in community-level ICT systems and services. One exemplar would be the move from community telecentre to individually-owned mobile phone as the epitomic technology in rural ICT4D. Second, that it is much easier for ICT initiatives to deal with individual, atomised farmers than to engage with the politics and inertia of wider social structures (Mohamad \& Gombe, 2017; Tenhunen, 2008).

Let us accept the widely-held assumption that community-level resilience will be of central importance to the future of rural and agricultural development (Wilson, 2010; 2012). There will thus be an argument for increasing the contribution of ICT4Ag to community resilience. There may be some slight tension between community and household resilience: we came across the example of improved community self-organisation through contract-based networks between farmer groups and suppliers, weakening household diversity \& flexibility by reducing incentives for crop diversification (Baumüller, 2015). But, conversely, there were other examples where strengthening community resilience had a positive knock-on for household resilience. For 
instance, the openness of market information at the community level influenced household equality (participation and inclusiveness) (Lwoga, 2010; Matuha, 2015). The recommendation for greater ICT4Ag focus on community resilience thus seems appropriate.

We can also look at the level of individual attributes, highlighting those where evidence to date shows relatively little contribution of ICT4Ag: household-level self-organisation and equality and almost all the attributes at community level. Assuming - and it is an important assumption - that all attributes are equally important to rural resilience, then we could recommend a greater priority for these as-yet underserved attributes; equal to that of the highestcontribution attributes.

Turning to features summarised in Figure D1, ICT4Ag systems will only function and will thus only impact resilience if there is some external drive or motivation - i.e. a perceived utility that influences actors to engage with the system. We saw this explicitly in relation to learning and to diversity \& flexibility at the household level, but it is an ICT4D universal (Heeks, 2018). The implication is that ICT-enabled resilience building must either identify and work with existing motivation to adopt and use technology, or must create such a perceived utility in relation to ICT4Ag systems, change and resilience (Berkes \& Ross, 2013; Béné et al., 2016).

The evidence above suggested that impacts were more often seen where there was less need for changes to the institutions and structural relations that form part of the wider livelihood system, and where the ICT used was relatively simple, thus requiring fewer complementary resources. However, such usages typically only result in small incremental improvements to the lives of agricultural households and communities (Baird \& Hartter, 2017; Dannenberg \& Lakes, 2013; Mtega \& Msungu, 2013) - note that the methodology used above only relates to prevalence of impact on resilience, not the depth of impact. To create a greater depth of impact on resilience then more transformative change may be required. Heeks (2018) formulates this in terms of a "DIRT ladder" of ICT impact: from simple Digitisation of existing processes, through ICT-enabled Improvement of processes and ICT-enabled system Reorganisation to structural Transformation.

But, to achieve this, may require two things. First, a shift from use of relatively simple ICT4AG systems, such as those based on basic mobile phones, to those based on more complex ICT systems, such as those mentioned above such as remote sensing data and GIS. This argument is supported by evidence from various studies (e.g. Krone et al., 2016; Garcia \& Fan, 2015; Sambasivan et al., 2016) that show greater developmental benefits achieved when more complex ICT systems are employed. Second, a greater extent of changes complementary to the introduction of digital: not merely the provision of resources that will enable the full information value chain to operate, but also parallel changes in the institutions and structures of the wider livelihood system. It should be noted, though, that implementing more complex systems and parallel systemic developments mean a greater extent of change and, hence, a greater risk of failure (Heeks, 2018). 
Figure E1 summarises the arguments made in this sub-section.

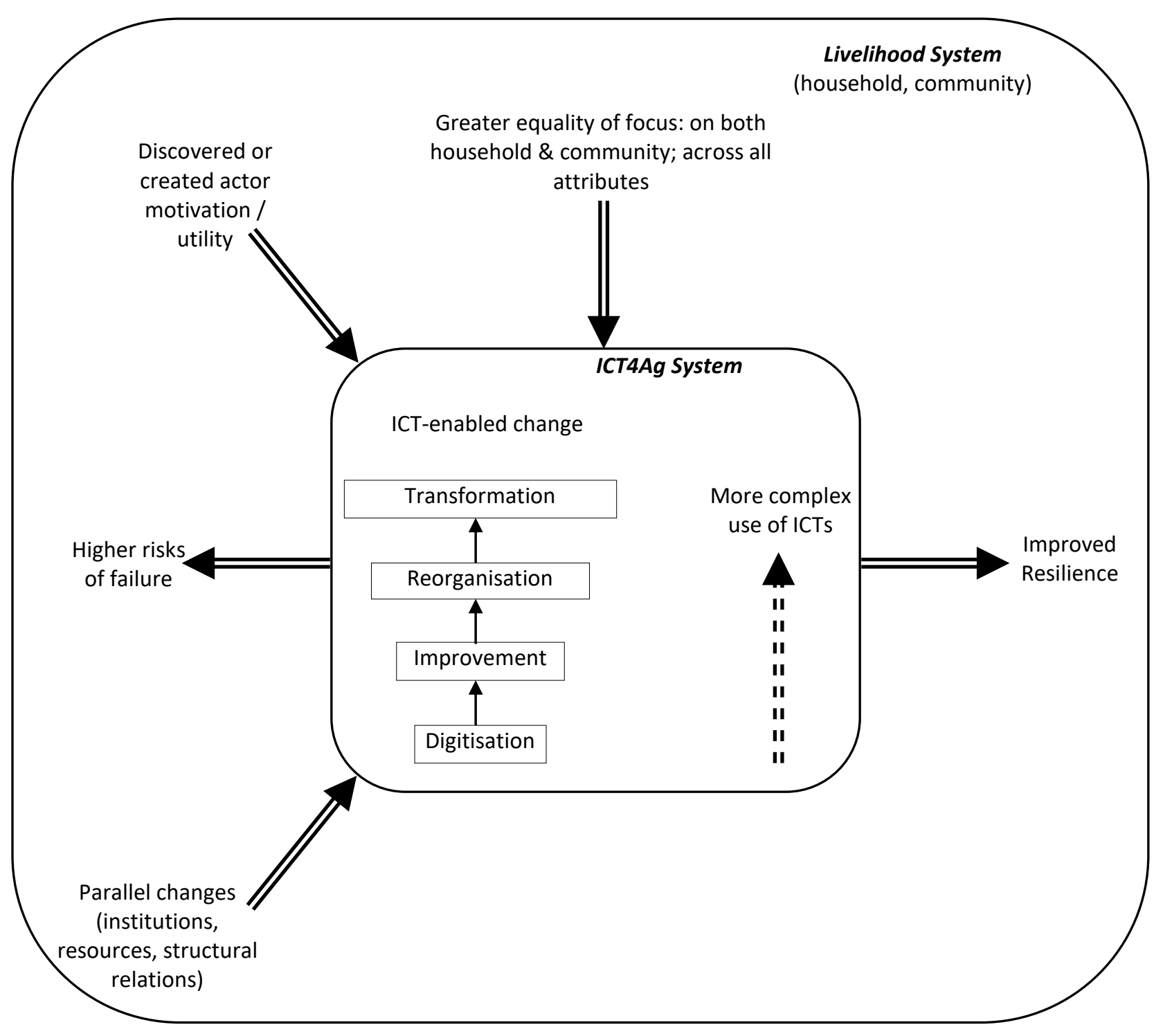

Figure E1: Summary of recommendations for practice

\section{E3. Policy Recommendations}

Three policy recommendations will be presented here, relating to three themes discussed in the two sub-sections above: the need for parallel changes, the resilience disbenefits ("negative impacts") associated with ICTs, and the need to attend more equally to household and community-level resilience.

As just summarised, other changes need to be implemented alongside ICT4D interventions. Regarding changes related to complementary information value chain resources, among other things, policies that encourage the expansion of power and telecommunications infrastructure, 
education and availability of finance in rural areas, will likely prove beneficial (Muto \& Yamano, 2009; World Bank, 2014). Such policies are more important when more complex applications of ICTs are involved; ones that are more demanding in terms of costs (the devices, services), capacities (skills and knowledge), and material requirements (technical infrastructure). Inclusive development policy approaches including those that seek to build state capacity may be relevant here (Bukenya \& Yanguas, 2013). Moreover, involvement of other institutions, such as educational institutions (e.g. universities), private sector providers, non-governmental organisations (NGOs), and developmental agencies, is also pivotal, since they can facilitate provision of knowledge, operation of advisory services, and changes in human behaviour; thus, addressing some specific resilience- or ICT-related challenges faced by farmers (Westermann et al., 2018).

Regarding the negative impacts of ICTs, evidence points mainly to equality and redundancy (costs of ICTs). One approach to improve this would be the expansion of technological and financial infrastructure to marginalised rural groups, as highlighted above. Other relevant interventions targeting marginalised rural groups would include policies that improve capability-building (e.g. skills, leadership, among others), affordability, and the flow of knowledge and information (Asongu et al., 2018; Heeks, 2016). Policies that facilitate the use of ICTs by other actors (e.g. NGOs, development agencies) when delivering information and services to marginalised rural groups can also be instrumental in improving digital inclusion (Foster \& Heeks, 2013; Heeks, 2016). In terms of affordability, pro-poor tax reforms that aim to improve ownership, adoption and use of ICTs among remote and poor households and communities can reduce cost burdens associated with ICTs. Alongside universal service obligations, there is also a potential for cost control through the utility of a quasi-independent regulatory body that monitors and regulates competition of, and costs (e.g. network interconnect costs) set by ICT service providers (e.g. telecommunication companies, Internet service providers) (Heeks, 2016; Payumo et al., 2017).

As regards improving the contribution of ICTs to community resilience, there may be a need to create an enabling environment that fosters the use of ICTs at the community level (Westermann et al., 2018; World Bank, 2012). Such an environment can promote awareness, participation, and social learning via social interactions and the role of "infomediaries" (Heeks, 2018). Additionally, policies that promote the coalescence of households into community-level units, such as farmer cooperatives, producer organisations, among others, can contribute to improving self-organisation and scale at the community level, which can serve as a foundation for ICT-enabled community-level resilience (CTA, 2014). Moreover, given the interdependence of different resilience levels, there is a need to promote awareness among practitioners and researchers of attending to all levels. 


\section{E4. A Critical Reflection on the RABIT Framework}

The RABIT framework has been instrumental in the analysis conducted here. It has provided a clear conceptual linkage between ICTs and resilience that has enabled extraction and analysis of evidence from the ICT4Ag literature. Its support for multi-scale analysis (both household and community) has provided a fuller understanding of rural resilience, and has formed a central element of the structure of the analysis. The resilience attributes and associated markers were central to the operationalisation of the framework, with most of the evidence fitting well into the existing attributes; thus, suggesting a good level of completeness. However, there were some challenges encountered during the analysis; these are discussed next alongside suggestions for improvements.

\section{E4.1 Incorporating individual actors and agency}

We have already noted the importance of the motivation of individuals and their perceptions of technology utility in gaining a full understanding of the pattern of reported ICT impacts on resilience. Alongside this there was evidence of needing to understand individual actors within those impacts, with examples of ICTs influencing the motivation, perception, and selfconfidence of household members to deal with resilience-related challenges and opportunities, especially after managing to use ICTs successfully in their agricultural activities. For example, some farmers were motivated to try new agricultural technologies after being exposed to and learning to use ICTs (Fu \& Akter, 2016); while others (e.g. fishers) were more confident in undertaking decisions or new courses of action knowing they have accurate information received through ICTs (Salia et al., 2011). There was also evidence of ICTs weakening motivation, primarily when farmers had bad experiences while using ICTs. For example, a farmer experiencing financial loss due to sales via the M-Farm platform was demotivated to try new technologies for agriculture (Ajwang, 2014). This did not readily fit with any of the existing attributes despite its obvious importance given it chimes with the analysis showing the importance of actor motivation and perceived utility.

More generally, within theories of sociology (e.g. Hurrelmann, 1988; Sewell, 1992; Shilling, 1992) and in the literature on climate adaptation (e.g. Adger, 2003; Brown \& Westaway, 2011; Grothmann \& Patt, 2005; Phillips, 2003) there is a good deal of agreement on the mutual interaction and importance of structure, process, resources and agency. Yet, looking at the RABIT framework, one can see a reflection of structure (physical preparedness, social and other networks, innovation mechanisms, etc.); of process (collaboration, reflective thinking, issue detection, etc.); and of resources (spareness, substitutability, scale of access, etc.). But notions of agency are not well represented: individuals and their driving forces are largely absent.

One way to deal with this would be to add a third, "nano-level" scope: analysing the impact of ICT4Ag on the resilience of individuals. Much has been written about the importance of individual-level resilience, including its importance within rural resilience (Brown \& Westaway, 2011; Kimhi, 2016; Sina et al., 2019). Thus there would be a logic and justification for this addition though the attributes would potentially need to be modified to make them appropriate to an individual person. An alternative would be to add a ninth "motivation" attribute to the general model which incorporated agency and drive for change through 
markers such as motivation for change, self-efficacy, and hope for the future. These are all known to be important in building individual resilience and also action on resilience more generally which would cascade upwards into household and community resilience (e.g. Berkes \& Ross, 2013; Brown \& Westaway, 2011; Heeks \& Krishna, 2016; Jones \& Tanner, 2017; Smith \& Frankenberger, 2018).

To reinforce this point, all resilience-building assumes action for change. But that action will not happen unless individual actors are motivated for change, believe they can make a difference, and that change will be positive. Thus, these motivational and dispositional aspects of human agency are arguably a foundation for resilience without which no other elements can occur. Such an addition would also have the advantage of combined the relatively objectivist approach to resilience that RABIT represents with the more subjectivist approach reflected in the sources cited just above.

\section{E4.2 Boundary-setting}

An inherent challenge of systems thinking is setting the system boundary (Berkes \& Ross, 2013; Heeks \& Ospina, 2019). Two attributes, self-organisation and scale, particularly required setting a boundary to determine what is inside and outside the system upon operationalisation; yet, this is not always clear, especially when analysing literature. For example, evidence of a farmers' group collaborating with police during cattle robbery (e.g. in Sife et al., 2010) can be classified under the self-organisation attribute (community-scope) if police are considered to be inside the boundary of the system (i.e. community), or under scale of resource access if they are considered outside the boundary. Similarly, whether evidence falls under intra-level or multi-level networks (under scale) largely depends on where the boundary is set. In both cases, a decision was made to set an institution outside a boundary unless there was clear evidence that it was within - but this was a choice that could have been made differently.

Similar decisions had to be made on other boundary issues. Under equality, the inclusiveness and participation marker was extended under household scope to mean inclusion of the household or its members within wider system functions, not just the functions of the household. There was also evidence of ICTs influencing trust, but not quite fitting under the self-organisation attribute, since the resources and individuals involved were outside the boundary of the system. For example, an individual farmer (household scope) building trust with an individual trader/customer (outside of household boundary) (Salia et al., 2011; Labonne \& Chase, 2009). On this, in future, trust might be included under the scale attribute, particularly because the two markers ("intra-level networks" and "multi-level networks") are concerned with linkages/network formation, which is known to be associated with trust (similar to "social network and trust" under self-organisation) (Carmody, 2013; Burrell \& Oreglia, 2015; Duncombe, 2016; Molony, 2006).

\section{E4.3 Incorporating power}

The livelihood system determinants shown in Figure D1 - resource control, institutional control, structural relations - are all determinants of power (Heeks \& Shekhar, 2019b). In turn, we know power to be an important determinant of resilience outcomes (Brown, 2016). Yet, just as 
with agency, the RABIT framework is currently rather limited in its incorporation of power. It is reflected to some degree in the equality attribute though even here we needed to provide an additional interpretation: under inclusiveness and participation at community level, we included evidence about power relations in markets (e.g. Ajwang, 2014; Furuholt \& Matotay, 2011) but only by somewhat broadening the intended coverage of this marker. The RABIT framework could therefore be modified to include markers that more explicitly represent determinants of power. The three equality markers are already helpful in this respect including control over resources - but issues of equality of control over institutions and within structural relations might be more explicitly recognised (Heeks, 2018).

\section{E4.4 Marker clarity}

A framework has to be generic enough to be applicable in varying situations (Béné, 2013), and we also acknowledge that the experience and knowledge of a researcher in his/her respective domain is important for interpretation and operationalisation of a framework (Chambers, 1997). Nonetheless, the absence of marker descriptions made a few markers challenging to understand, mainly due to potential overlap with other markers. For example, the "institutional capacity" marker under robustness has potential overlap with the "local leadership" and "collaboration and consensus-building" markers under self-organisation, and the "capacity building" marker under learning. Similarly, the "social networks and trust" marker under self-organisation at the community level has some potential overlap with the "intra-level networks" marker under scale at the community level.

While the operationalisation of these was resolved during the initial inter-coder discussions, the absence of marker descriptions was a problem; indeed, much of the initial inter-coder discussion centred around development of greater clarity about markers. We thus see that a generic descriptions of markers is useful for operationalisation of the RABIT framework; an argument that concurs with Heeks \& Ospina (2019), who recommended associating descriptors and even explicit indicators with each of the markers to improve their operationalisation. Given this, a matrix of the descriptions and examples of how the markers were understood and operationalised in this research is included in Appendix C, with the hope that such details will contribute to the improvement of the RABIT framework operationalisation.

\section{E4.5 Methodological limitations}

Our application of the RABIT framework has implicitly assumed equal weighting for all attributes and markers. This can be questioned generically: for example, one could argue that the foundational attributes should be given a greater weighting. And it can be questioned contextually: in any particular rural area, the population might very well award a higher weighting to some framework components than others. Ideally, that would be recognised in some way in applying the model by allowing an attribute-weighting stage where relevant.

Another limitation already noted above is that our literature analysis was based on binary measurement: counting a source if it mentioned an impact that could be related to a marker or attribute; excluding it if not. But this tells us nothing about the depth of impact; treating equally a source identifying a slight effect and one identifying a transformative effect. We have 
brought this issue into the discussion above but could consider some impact scale being associated with each of the resilience attributes/markers to indicate by how much they are changing as the result of, say, an ICT-based intervention.

\section{E5. Limitations and Future Research}

There were some limitations associated with this research in addition to those implicit within our critical reflections in Section D3. Initial co-coding was undertaken: an iterative process over the course of some weeks between both authors of discussing specific impact examples from the literature, their classification against level (household / community), attributes and markers which led to considerable clarification and agreement on the definition, nature and boundaries of those three elements (as reflected, for example, in Appendix C). However, the remainder of the literature coding was then undertaken by one person - author Hanson - where dual coding could have improved overall rigour. We also acknowledge that this was post-hoc reinterpretation of ICT4Ag literature meaning that selection of focal framework and author preconceptions will have influenced that interpretation.

Interpretation was also limited by the nature of the evidence that is reported in the selected literature. What we analyse here is not the reality of ICTs-in-agriculture, nor the reality of ICTs' impact on rural resilience. Instead it is analysis of what writers have chosen to report. Use of a reasonable number of sources should have helped here, avoiding biases that might be present within a smaller sample. However, we noted above the possibility that the much smaller impact on community compared to household resilience could in part be an artefact of reporting. Likewise, a bias towards documenting positive impacts could explain some of the imbalance between strengthening vs. weakening of resilience. Both of these issues must be handled more equitably in future research.

A key point noted during initial and full coding was that the intended focus for resilience is disturbances external to the system, which were understood in terms of short-term shocks and longer-term trends. However, in interpreting the evidence, we relied far more on ICTs' impact on core, regular system activities; most particularly the conventional agricultural value chain from purchase of inputs through growth of products to their sales. This is because - while there was a little evidence of shocks, such as animal attacks - this formed only a small minority of the evidence base. Solely relying on shock-/trend-based evidence would therefore have made it impossible to perform a credible analysis.

All this points to the value of moving from a post-hoc to a pre-hoc approach; going into the field armed with the RABIT framework (amended, potentially, as suggested earlier in relation to agency and power, and to localised attribute weighting and impact measurement) and gathering primary data against each of the attributes and markers in relation to the impact of ICTs-in-agriculture. The RABIT framework explains what the impact of ICTs is on resilience. The new model outlined in Figure D1 can be used as a complement in future research; helping to explain why this impact is seen. 


\section{Appendix A: ICT4Ag Literature Mentioning Resilience}

Appendix A presents a summary of the articles found during the review of ICTs-in-agriculture, which specifically mentioned resilience.

The top three ICT4D journals (Information Technology for Development, Information Technologies and International Development, and The Electronic Journal of Information Systems in Developing Countries) were searched using the string "resilien*", but no relevant article on resilience and ICT4Ag was found. Then Google Scholar (excluding patents and citations) was searched using three different search strings, as summarised in Table AA1.

Table AA1: Google Scholar search string and results counts

\begin{tabular}{|l|l|}
\hline Search string & $\begin{array}{l}\text { Number of results } \\
\text { returned }\end{array}$ \\
\hline $\begin{array}{l}\text { intitle:resilience AND (intext:“ICT4AG” OR intext:“e-agriculture” OR } \\
\text { intext:ICT4D OR intext:ICTD) }\end{array}$ & 34 \\
\hline $\begin{array}{l}\text { intitle:resilience intitle:agriculture OR intitle:agricultural AND } \\
\text { intext: “information and communication technologies” }\end{array}$ & 8 \\
\hline $\begin{array}{l}\text { (intitle:resilience OR intitle:resilient intext:resilience) (intext:ICT4D OR } \\
\text { intext:ICTs OR intext:ICTD) (intext:agriculture OR intext:agricultural OR } \\
\text { intext:farming) developing countries }\end{array}$ & 148 \\
\hline
\end{tabular}

These were reviewed and combined to produce thirteen articles, that were in some way discussing agriculture (or at least have the word "agriculture" in the body), ICT and at least the word "resilience" in the title. Table AA2 presents a summary of these articles; indicating the lack of literature on ICT4Ag and resilience and hence requiring the re-analysis of a wider body of ICT4Ag literature using a resilience framework.

Note that the projects whose frameworks were identified (NICCD: Nexus for ICTs, Climate Change and Development and DEAR: Digital Engagement and Resilience), were also searched, and two more case studies from NICCD were identified - Heeks \& Ospina (2016a; 2016b) which are utilised in the main text. 
Table AA2: Articles Summary Review

\begin{tabular}{|c|c|c|c|c|}
\hline Author & Title & Year & Focus categorisation & Comments \\
\hline Ospina \& Heeks (2010) & $\begin{array}{l}\text { Linking ICTs and climate change adaptation: A conceptual framework for e- } \\
\text { resilience and e-adaptation }\end{array}$ & 2010 & Resilience Framework & Related to the RABIT framework; building e-resilience framework. \\
\hline Douxchamps et al. (2017) & $\begin{array}{l}\text { Monitoring and evaluation of climate resilience for agricultural development-a } \\
\text { review of currently available tools }\end{array}$ & 2017 & ICT4Ag & No focus on ICT. \\
\hline Heeks \& Ospina (2015) & Analysing urban community informatics from a resilience perspective & 2015 & ICT4D & $\begin{array}{l}\text { There is a focus on resilience and ICTs. But it is on urban communities, not rural } \\
\text { and agriculture. }\end{array}$ \\
\hline Muktar et al. (2018b) & $\begin{array}{l}\text { Evaluation of ICTs access, use and preferences for livelihood resilience: results from } \\
\text { a survey of Malaysian fisherfolks }\end{array}$ & 2018 & ICT4Ag & $\begin{array}{l}\text { Resilience is defined, but not used as a lens for evaluation (Sustainable Livelihoods } \\
\text { Approach is used instead). }\end{array}$ \\
\hline Ozor et al. (2015) & $\begin{array}{l}\text { Using the Land Potential Knowledge System (LandPKS) mobile technology for } \\
\text { agricultural productivity and resilience }\end{array}$ & 2015 & ICT4Ag & $\begin{array}{l}\text { Resilience is only mentioned as a word. No definition or any theoretical linkage is } \\
\text { made. }\end{array}$ \\
\hline Muktar et al. (2018b) & $\begin{array}{l}\text { Fishers ICTs use for early warning reception, it's effect on livelihood resilience and } \\
\text { sustainability in East Coast Malaysia }\end{array}$ & 2018 & ICT4Ag & $\begin{array}{l}\text { There is a focus on resilience though not too detailed; the term is used to build the } \\
\text { concept of livelihood resilience. But the article then uses Protective Motivation } \\
\text { Theory to carry out an analysis. }\end{array}$ \\
\hline Haworth et al. (2018) & $\begin{array}{l}\text { Geographic information and communication technologies for supporting } \\
\text { smallholder agriculture and climate resilience }\end{array}$ & 2018 & ICT4Ag & $\begin{array}{l}\text { Resilience is only mentioned as a word. No definition or any theoretical linkage is } \\
\text { made. }\end{array}$ \\
\hline Jimenez \& Ramirez-Villegas (2018) & $\begin{array}{l}\text { Unlocking big data's potential to strengthen farmers' resilience: the platform for big } \\
\text { data in agriculture }\end{array}$ & 2018 & ICTAAg & $\begin{array}{l}\text { Resilience is only mentioned as a word. No definition or any theoretical linkage is } \\
\text { made. More focussed on big data. }\end{array}$ \\
\hline Ozor (2015) & $\begin{array}{l}\text { Improving agricultural productivity and resilience to climate change using the Land } \\
\text { Potential Knowledge System (LandPKS) mobile technology }\end{array}$ & 2015 & ICT4Ag & Techno-centric; no definition or any theoretical linkage to resilience is made. \\
\hline Verma et al. (2017) & Crafting climate resilience for people at bottom of pyramid using digital innovation & 2017 & ICT4Ag & Resilience is only mentioned in the title. \\
\hline Baliwada et al. (2014) & Climate resilient technologies for sustainable agriculture & 2014 & ICT4Ag & Resilience is not defined nor is a resilience conceptual framework used. \\
\hline Ospina \& Heeks (2016) & Resilience Assessment Benchmarking and Impact Toolkit (RABIT) & 2016 & Resilience framework & Uses the RABIT framework. \\
\hline Ospina et al. (2016) & $\begin{array}{l}\text { Benchmarking urban community resilience: piloting the Resilience Assessment } \\
\text { Benchmarking and Impact Toolkit (RABIT) in Costa Rica }\end{array}$ & 2016 & ICT4D & A focus on urban resilience, not rural/agriculture. \\
\hline
\end{tabular}


Table AB1: Unique article weakness and strength resilience attribute mapping

\begin{tabular}{|c|c|c|c|c|c|c|c|c|c|c|c|c|c|c|c|c|c|c|c|c|c|c|c|c|c|c|c|c|c|c|c|c|c|}
\hline \multirow{4}{*}{$\begin{array}{l}\text { Article } \\
\text { reference } \\
\text { number }\end{array}$} & \multicolumn{16}{|c|}{ Household } & \multicolumn{16}{|c|}{ Community } & \multirow{4}{*}{ Grand Total } \\
\hline & \multicolumn{6}{|c|}{ Foundational } & \multicolumn{10}{|c|}{ Enabling } & \multicolumn{6}{|c|}{ Foundational } & & & & & & nablin & & & & & \\
\hline & Lear & ning & Robu: & thess & $\begin{array}{r}\mathrm{S} \\
\text { Organ }\end{array}$ & ation & $\begin{array}{r}\text { Dive } \\
\& \\
\text { Flexi }\end{array}$ & $\begin{array}{l}\text { sity } \\
\text { ility }\end{array}$ & Equ & ality & Rapi & dity & Redur & lancy & Sc & & Lea & ning & Robus & tness & $\begin{array}{r}5 \\
\text { Orgar }\end{array}$ & ation & $\begin{array}{r}\text { Dive } \\
\& \\
\text { Flexi }\end{array}$ & $\begin{array}{l}\text { sity } \\
\text { ility }\end{array}$ & Equ & ality & Rapi & idity & Redu & dancy & & & \\
\hline & 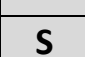 & $\mathbf{w}$ & S & $w$ & $\mathrm{~s}$ & w & 5 & $w$ & S & w & s & w & $\mathrm{s}$ & $\mathbf{w}$ & $\mathrm{s}$ & $\mathbf{w}$ & $\mathrm{s}$ & $\mathbf{w}$ & s & w & $\mathrm{s}$ & w & $s$ & w & $S$ & w & $\mathrm{s}$ & $\mathbf{w}$ & $s$ & w & $\mathrm{s}$ & w & \\
\hline 1 & 1 & & 1 & & & & 1 & & 1 & & 1 & & 1 & & 1 & & 1 & & 1 & & 1 & & & & & & & & 1 & & 1 & & 12 \\
\hline 2 & 1 & & 1 & & & & 1 & & 1 & & & & & & & & & & & & & & & & & & & & & & & & 4 \\
\hline 3 & & & & & & & 1 & & & & & & & & & & & & & & & & & & & 1 & & & & & & & 2 \\
\hline 4 & 1 & & & & & & & & & & 1 & & 1 & & 1 & & & & & & & & & & & & & & & & & & 4 \\
\hline 5 & 1 & & 1 & & 1 & & 1 & & & 1 & 1 & & 1 & & 1 & & & & & & & & & & & & & & & & & & 8 \\
\hline 6 & 1 & & 1 & & 1 & 1 & 1 & & 1 & 1 & 1 & & 1 & & 1 & & & & & 1 & 1 & 1 & & & & & & & & & & & 13 \\
\hline 7 & & & 1 & & & & & & & & & & 1 & & & & & & & & & & & & 1 & & & & & & & & 3 \\
\hline 8 & 1 & & 1 & & & & 1 & & & & & & 1 & & 1 & & & & & & 1 & & & 1 & & & & & & & & & 7 \\
\hline 9 & 1 & & 1 & & & & 1 & & & & & & 1 & & & & & & & & & & & & & 1 & & & & & & & 5 \\
\hline 10 & 1 & & & & & & 1 & & 1 & & 1 & & 1 & & 1 & & & & & & 1 & & & & & 1 & & & 1 & & 1 & & 10 \\
\hline 11 & 1 & & & & & & & & & & 1 & & 1 & & 1 & & & & & & & & & & & & & & & & & & 4 \\
\hline 12 & 1 & & & & & & & & 1 & 1 & 1 & & & & & & & & & & & & & & 1 & & & & & & & & 5 \\
\hline 13 & 1 & & 1 & & 1 & & 1 & & 1 & & 1 & & 1 & 1 & 1 & & & & & & 1 & & & & 1 & & & & 1 & & & & 12 \\
\hline 14 & 1 & & 1 & & & & 1 & & & & 1 & & 1 & 1 & 1 & & & & & & & & & & & & & & & & & & 7 \\
\hline 15 & 1 & & & & & & & & & & & & 1 & & & & & & & & & & & & & & & & & & & & 2 \\
\hline 16 & & & 1 & & & & 1 & & 1 & & & & 1 & & & & & & & & & & & & & & & & & & & & 4 \\
\hline 17 & & & 1 & & & & 1 & & 1 & & & & 1 & & & & & & & & & & & & & 1 & & & & & & & 5 \\
\hline 18 & 1 & & & & & & & & 1 & & & & & & 1 & & & & & & 1 & & & & & 1 & & & & & & 1 & 6 \\
\hline 19 & 1 & & 1 & & & & 1 & & 1 & & & & 1 & & 1 & & & & & & & & & & & & & & & & & & 6 \\
\hline 20 & & 1 & 1 & & 1 & & 1 & & 1 & & 1 & & 1 & & & & 1 & & 1 & 1 & 1 & & & & & & 1 & & & & 1 & & 13 \\
\hline 21 & 1 & & & & & & & & 1 & & & & & & 1 & & 1 & & 1 & & 1 & & & & & 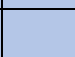 & & & 1 & & 1 & & 8 \\
\hline 22 & 1 & & & & & & 1 & & & 1 & 1 & & 1 & & 1 & & & & & & & & & & & 1 & & & & & & & 7 \\
\hline 23 & 1 & & 1 & & & & 1 & & & & 1 & & 1 & & 1 & & & & 1 & & 1 & & 1 & & 1 & & 1 & & 1 & & & & 12 \\
\hline 24 & 1 & & & & & & 1 & & & & 1 & & 1 & & 1 & & & & & & 1 & & & & & & & & & & & & 6 \\
\hline 25 & 1 & & 1 & & 1 & & & & & & 1 & & 1 & & 1 & & 1 & & & & 1 & & & & & & 1 & & 1 & & 1 & & 11 \\
\hline 26 & & & 1 & & 1 & & 1 & & 1 & & 1 & & 1 & 1 & 1 & & & & & & 1 & & & & & & & & & & & & 9 \\
\hline 27 & 1 & & 1 & & 1 & & 1 & & & & 1 & & 1 & & & & & & & & 1 & & & & & & & & & & 1 & & 8 \\
\hline 28 & 1 & & 1 & & & & 1 & & & & 1 & & 1 & & & & & & & & & & & & & & & & & & 1 & & 6 \\
\hline 29 & 1 & & & & & & 1 & & & & 1 & & 1 & & 1 & & & & & & & & & & & & & & & & & & 5 \\
\hline 30 & 1 & & 1 & & 1 & & 1 & & & & & & 1 & & & & & & & & & & & & 1 & & & & & & & & 6 \\
\hline 31 & & & & & & & 1 & & & & 1 & & 1 & & 1 & & & & & & & & & & 1 & & & & & & & & 5 \\
\hline 32 & & & & & & & & & & & & & 1 & & & & & & & & & & & & & & & & & & & & 1 \\
\hline 33 & & & & & & & & & & & & & 1 & & & & & & & & 1 & & & & 1 & & & & & & & & 3 \\
\hline 34 & 1 & & & & & & & & & & & & 1 & 1 & 1 & & & & & & & & & & & & & & & & & & 4 \\
\hline 35 & 1 & & & & & & 1 & & & & 1 & & 1 & & 1 & & & & & & & & & & & & & & & & & & 5 \\
\hline 36 & 1 & & 1 & & 1 & & 1 & & & & 1 & & 1 & 1 & 1 & & & & & & & & & & & 1 & & & & & & & 9 \\
\hline 37 & 1 & & 1 & & & & 1 & & & & 1 & & 1 & & & & & & & & & & & & & & & & & & & & 5 \\
\hline 38 & 1 & & 1 & & & & & & & 1 & 1 & & & & 1 & & 1 & & & & 1 & & 1 & & & & 1 & & & & & & 9 \\
\hline 39 & & & 1 & & 1 & & 1 & & & & 1 & & 1 & & 1 & & & & & & 1 & & & & & & & & & & & & 7 \\
\hline 40 & & & & & & & 1 & & 1 & & & & 1 & & 1 & & & & & & & & & & & & & & & & & & 4 \\
\hline 41 & & & & & & & & & 1 & & & & 1 & & & & & & & & & & & & & & & & & & & & 2 \\
\hline 42 & & & & & 1 & & 1 & & & & 1 & & & & & & & & & & 1 & & & & & & & & & & & & 4 \\
\hline 43 & 1 & & & & 1 & & 1 & & & & 1 & & 1 & & 1 & & & & & & & & & & & & & & & & & & 6 \\
\hline 44 & 1 & & & & & & 1 & & 1 & & & & & & & & & & & & & & 1 & & & & & & & & & & 4 \\
\hline 45 & & & 1 & & & & 1 & & & & & & 1 & & 1 & & & & & & & & & & & & & & & & & & 4 \\
\hline Total & 31 & 1 & 24 & 0 & 12 & 1 & 32 & 0 & 16 & 5 & 26 & 0 & 37 & 5 & 27 & 0 & 5 & 0 & 4 & 2 & 17 & 1 & 3 & 1 & 7 & 7 & 4 & 0 & 6 & 0 & 7 & 1 & 282 \\
\hline
\end{tabular}

Key: S - Strength, W-Weakness 


\begin{tabular}{|c|c|}
\hline $\begin{array}{l}\text { Resilience } \\
\text { Attributes }\end{array}$ & Key Markers/Indicators \\
\hline \multicolumn{2}{|c|}{ FOUNDATIONAL ATTRIBUTES OF HOUSEHOLD/ COMMUNITY RESILIENCE } \\
\hline Robustness & $\begin{array}{l}\text { - Physical preparedness (physical ability to withstand or recover from shocks) } \\
\text { - Institutional capacity (ability of institutional sub-systems to function including withstanding or } \\
\text { recovering from shocks) } \\
\text { - Loose functional coupling (relative independence of sub-systems so that collapse in one does } \\
\text { not have a domino effect on others) }\end{array}$ \\
\hline $\begin{array}{l}\text { Self- } \\
\text { Organisation }\end{array}$ & $\begin{array}{l}\text { - Collaboration and consensus-building (extent of mechanisms that enable collaborative } \\
\text { decision-making and other activities) } \\
\text { - Social networks and trust (extent of structures and other bases for self-organising actions incl. } \\
\text { bonding social capital within system) } \\
\text { - Local leadership (in order to drive or guide self-organisation) }\end{array}$ \\
\hline Learning & $\begin{array}{l}\text { - Capacity building (ability to create new skills and related competencies: capacity to learn and } \\
\text { implement learning) } \\
\text { - Reflective thinking (extent of specific learning processes) } \\
\text { - New and traditional knowledge (indicators that learning has been achieved through the } \\
\text { creation or exposure of knowledge) }\end{array}$ \\
\hline \multicolumn{2}{|c|}{ ENABLING ATTRIBUTES OF HOUSEHOLD/ COMMUNITY RESILIENCE } \\
\hline Redundancy & $\begin{array}{l}\text { - Resource spareness (extent of availability of resources beyond basic system functioning } \\
\text { requirements) } \\
\text { - Resource substitutability (extent to which resources can substitute for one another within and } \\
\text { between categories) } \\
\text { - Functional overlaps (extent of sub-systems that can substitute functionally for one another if } \\
\text { one sub-system collapses) }\end{array}$ \\
\hline Rapidity & $\begin{array}{l}\text { - Rapid issue detection (speed of detecting an external opportunity or disturbance e.g. via } \\
\text { data/information from early warning systems) } \\
\text { - Rapid issue assessment (speed of assessing the nature (e.g. deciding on likely risk and impact) } \\
\text { of an external disturbance) } \\
\text { - Rapid issue response (speed of mobilising resources in response to external disturbance) }\end{array}$ \\
\hline Scale & $\begin{array}{l}\text { - Scale of resource access (size and source diversity of access to resources like money, } \\
\text { technology, food, information, etc.) } \\
\text { - Multi-level networks (structural basis (e.g. linking social capital) for access to resources beyond } \\
\text { the system) } \\
\text { - Intra-level networks (structural basis (e.g. bridging social capital between different units of } \\
\text { system) for access to resources within the system) }\end{array}$ \\
\hline $\begin{array}{l}\text { Diversity \& } \\
\text { Flexibility }\end{array}$ & $\begin{array}{l}\text { - Variety of courses of action (number of different actions that could be taken e.g. in response } \\
\text { to an external disturbance or to take advantage of opportunities) } \\
\text { - Adaptable decision-making (ability of decision-making in the system to cope with problems or } \\
\text { opportunities) } \\
\text { - Innovation mechanism (basis for developing new ideas, processes and technologies within the } \\
\text { system) }\end{array}$ \\
\hline Equality & $\begin{array}{l}\text { - Equality of distribution of assets (across inter-sectional dimensions and including all livelihood } \\
\text { capitals: human, financial, natural, social, physical) } \\
\text { - Inclusiveness and participation (within key system functions including decision-making) } \\
\text { - Openness and accountability (of key system functions including decision-making) }\end{array}$ \\
\hline
\end{tabular}


Table AC2: Resilience marker descriptors: detailed multi-level description and examples

\begin{tabular}{|c|c|c|c|c|c|c|}
\hline \multirow{2}{*}{$\begin{array}{l}\text { Resilience } \\
\text { Attributes }\end{array}$} & \multirow[t]{2}{*}{ Definition } & \multirow{2}{*}{$\begin{array}{l}\text { Key Markers/ } \\
\text { Indicators }\end{array}$} & \multicolumn{2}{|c|}{ Community Resilience } & \multicolumn{2}{|c|}{ Household Resilience } \\
\hline & & & Description & Examples & Description & Examples \\
\hline \multicolumn{7}{|c|}{ FOUNDATIONAL ATTRIBUTES OF RESILIENCE } \\
\hline \multirow{3}{*}{ Robustness } & \multirow{3}{*}{$\begin{array}{l}\text { The ability of the } \\
\text { household/community to } \\
\text { maintain its characteristics } \\
\text { and performance in the } \\
\text { face of environmental } \\
\text { shocks and fluctuations. }\end{array}$} & \begin{tabular}{|l} 
Physical \\
preparedness
\end{tabular} & $\begin{array}{l}\text { Physical preparedness of the } \\
\text { community/community-level body } \\
\text { because of using ICTs. }\end{array}$ & $\begin{array}{l}\text { Community-organised group improve walls in } \\
\text { the riverbank in preparation for expected heavy } \\
\text { rain due to information received through ICTs. }\end{array}$ & $\begin{array}{l}\text { Physical preparedness at the household level } \\
\text { because of using ICTs. }\end{array}$ & $\begin{array}{l}\text { Planting seeds that take a short time to } \\
\text { harvest due to information of insufficient } \\
\text { rainfall through ICTs. }\end{array}$ \\
\hline & & $\begin{array}{l}\text { Institutional } \\
\text { capacity }\end{array}$ & $\begin{array}{l}\text { ICTs enabling community or community- } \\
\text { level body as a unit to continue to function } \\
\text { in the face of shocks/fluctuations. }\end{array}$ & $\begin{array}{l}\text { Farmers living close to the national parks } \\
\text { reporting poaching activities to the } \\
\text { authorities/wildlife patrols through ICTs, thus } \\
\text { enabling the capacity of the patrol group. }\end{array}$ & $\begin{array}{l}\text { ICTs enabling household as a unit to continue to } \\
\text { function in the face of shocks/fluctuations. }\end{array}$ & $\begin{array}{l}\text { Evidence of ICTs improving the capacity of the } \\
\text { household to deal with a shock by facilitating } \\
\text { better communications. }\end{array}$ \\
\hline & & $\begin{array}{l}\text { Loose functional } \\
\text { coupling }\end{array}$ & $\begin{array}{l}\text { ICTs enabling community/community-level } \\
\text { body to function with minimum } \\
\text { dependency on other bodies. }\end{array}$ & $\begin{array}{l}\text { Evidence of ICTs helping advisory systems to } \\
\text { operate with minimum dependency on } \\
\text { transportation system/department/body. }\end{array}$ & $\begin{array}{l}\text { ICTs enabling households to function } \\
\text { independently; that is with no dependency on } \\
\text { another household. }\end{array}$ & $\begin{array}{l}\text { Evidence of ICTs reducing the dependency of a } \\
\text { household on another household for obtaining } \\
\text { agricultural information. }\end{array}$ \\
\hline \multirow{3}{*}{$\begin{array}{l}\text { Self- } \\
\text { Organisation }\end{array}$} & \multirow{3}{*}{$\begin{array}{l}\text { The ability of the } \\
\text { household/community to } \\
\text { independently re-arrange } \\
\text { its functions and } \\
\text { processes in the face of an } \\
\text { external disturbance, } \\
\text { without being forced by } \\
\text { external influences. }\end{array}$} & \begin{tabular}{|l|} 
Collaboration \\
and consensus- \\
building
\end{tabular} & $\begin{array}{l}\text { The use of ICTs to improve/encourage } \\
\text { collaboration and consensus-building of } \\
\text { the community or among members of the } \\
\text { community via a community-level body. }\end{array}$ & $\begin{array}{l}\text { Community members use of mobile phones to } \\
\text { organise community events to drive away } \\
\text { baboons; a notorious crop-raiding species. }\end{array}$ & $\begin{array}{l}\text { The use of ICTs during collaboration/consensus } \\
\text { building that impacts the household. This excludes } \\
\text { uses that specifically target the household head as } \\
\text { they fall under local leadership. }\end{array}$ & $\begin{array}{l}\text { ICTs improving collaboration among } \\
\text { household members when deciding farming } \\
\text { practices, etc. }\end{array}$ \\
\hline & & \begin{tabular}{|l|} 
Social networks \\
and trust
\end{tabular} & $\begin{array}{l}\text { The use of ICTs that facilitate building } \\
\text { networks that can coalesce into a single } \\
\text { community system. }\end{array}$ & $\begin{array}{l}\text { ICTs allowing farmers to form and maintain } \\
\text { groups easily. }\end{array}$ & $\begin{array}{l}\text { ICTs improving social networks and trust among } \\
\text { household members. }\end{array}$ & $\begin{array}{l}\text { Farmers using mobile phones to stay } \\
\text { connected with family during farming } \\
\text { activities, especially when farming activities } \\
\text { are undertaken away from home for an } \\
\text { extended period. }\end{array}$ \\
\hline & & \begin{tabular}{|l|} 
Local leadership \\
\end{tabular} & $\begin{array}{l}\text { The use of ICTs to improve community- } \\
\text { level leadership or leadership of a } \\
\text { community-level body. }\end{array}$ & $\begin{array}{l}\text { ICTs helping the leader of a farmer group to } \\
\text { coordinate group activities. }\end{array}$ & $\begin{array}{l}\text { The use of ICTs by the household head when } \\
\text { providing guidance and leadership in the } \\
\text { household. }\end{array}$ & $\begin{array}{l}\text { The use of mobile phones by the household } \\
\text { head to provide instructions and guidance } \\
\text { when a child is sick. }\end{array}$ \\
\hline \multirow{3}{*}{ Learning } & \multirow{3}{*}{$\begin{array}{l}\text { The capacity of the } \\
\text { household/community to } \\
\text { generate feedback with } \\
\text { which to gain or create } \\
\text { knowledge and strengthen } \\
\text { skills and capacities. } \\
\text { Closely linked to the } \\
\text { household's ability to } \\
\text { experiment, discover and } \\
\text { innovate. }\end{array}$} & $\begin{array}{l}\text { Capacity } \\
\text { building }\end{array}$ & $\begin{array}{l}\text { Community's or community-level body's } \\
\text { learning capacity building facilitated using } \\
\text { ICTs. }\end{array}$ & $\begin{array}{l}\text { Community-level body using ICTs to acquire } \\
\text { skills that improve its learning capacity. }\end{array}$ & $\begin{array}{l}\text { Household building learning capacity due to either } \\
\text { using ICTs to get opportunities to learn, or } \\
\text { improving skills, e.g. reading, writing due to using } \\
\text { ICTs, that then bolster learning capacity. }\end{array}$ & $\begin{array}{l}\text { Farmers learning how to use online platforms } \\
\text { to gain more knowledge about agricultural } \\
\text { practices. }\end{array}$ \\
\hline & & \begin{tabular}{|l|} 
New and \\
traditional \\
knowledge
\end{tabular} & $\begin{array}{l}\text { The use of ICTs in preserving, informing } \\
\text { and promoting the use of new and } \\
\text { traditional knowledge at the community } \\
\text { level and among community-level bodies. }\end{array}$ & $\begin{array}{l}\text { The use of a mobile phone to share traditional } \\
\text { knowledge between two generation groups in } \\
\text { pastoralist societies (e.g. elders and warriors). }\end{array}$ & $\begin{array}{l}\text { The use of ICTs to access and learn about new } \\
\text { knowledge at the household level. }\end{array}$ & $\begin{array}{l}\text { Farmers using a mobile phone to access new } \\
\text { knowledge about agricultural practices. }\end{array}$ \\
\hline & & \begin{tabular}{|l} 
Reflective \\
thinking
\end{tabular} & $\begin{array}{l}\text { The use of ICTs among community-level } \\
\text { bodies to identify gaps based on what is } \\
\text { known, and acquire new knowledge to } \\
\text { address those gaps. }\end{array}$ & $\begin{array}{l}\text { The use of ICTs among farmers cooperating to } \\
\text { brainstorm challenges and identify solutions to } \\
\text { the problems they face. }\end{array}$ & $\begin{array}{l}\text { Individual households using ICTs to identify gaps } \\
\text { based on what is known and acquire new } \\
\text { knowledge to address those gaps. }\end{array}$ & $\begin{array}{l}\text { Farmers using ICTs to identify diseases } \\
\text { infecting their produce, and find ways to treat } \\
\text { them. }\end{array}$ \\
\hline \multicolumn{7}{|c|}{ ENABLING ATTRIBUTES OF RESILIENCE } \\
\hline \multirow{3}{*}{ Redundancy } & \multirow{3}{*}{$\begin{array}{l}\text { The extent to which } \\
\text { household/community } \\
\text { resources and institutions } \\
\text { are substitutable; for } \\
\text { example, in the event of } \\
\text { disruption or degradation. }\end{array}$} & \begin{tabular}{|l|} 
Resource \\
spareness
\end{tabular} & $\begin{array}{l}\text { ICTs facilitating resource spareness (e.g. } \\
\text { saving money and time, increasing } \\
\text { income) at community level / in a } \\
\text { community-level body. }\end{array}$ & $\begin{array}{l}\text { Groups of farmers use ICTs to mobilise and then } \\
\text { collectively negotiate better tractor prices } \\
\text { together. }\end{array}$ & $\begin{array}{l}\text { ICTs facilitating resource spareness (e.g. saving } \\
\text { money and time, increasing income) at household } \\
\text { level. }\end{array}$ & $\begin{array}{l}\text { Farmers reducing the cost of farming-related } \\
\text { transactions due to the use of mobile money } \\
\text { services. }\end{array}$ \\
\hline & & \begin{tabular}{|l|} 
Resource \\
substitutability
\end{tabular} & $\begin{array}{l}\text { ICTs facilitating substitutability of } \\
\text { community-level resources and } \\
\text { institutions. }\end{array}$ & $\begin{array}{l}\text { A community radio using data from the internet } \\
\text { to substitute or supplement data previously } \\
\text { provided locally. }\end{array}$ & $\begin{array}{l}\text { ICTs facilitating substitutability of household } \\
\text { resources. }\end{array}$ & Journey substitution at the household level. \\
\hline & & \begin{tabular}{|l} 
Functional \\
overlaps
\end{tabular} & $\begin{array}{l}\text { ICTs used at community/community-level } \\
\text { body to provide similar functionality to } \\
\text { existing resources/systems. }\end{array}$ & $\begin{array}{l}\text { Community radio using two channels - SMS or } \\
\text { calls - to allow farmer to submit queries which } \\
\text { were then responded via radio for wide impact. }\end{array}$ & $\begin{array}{l}\text { ICTs impacting household due to the various } \\
\text { functionalities it offers that either substitute, } \\
\text { complement or enhance existing functional needs. }\end{array}$ & $\begin{array}{l}\text { The use of mobile-based agricultural } \\
\text { information platforms alongside face-to-face } \\
\text { means of sharing information. }\end{array}$ \\
\hline \multirow{2}{*}{ Rapidity } & \multirow{2}{*}{$\begin{array}{l}\text { The speed at which assets } \\
\text { can be accessed or } \\
\text { mobilised by } \\
\text { household/community } \\
\text { stakeholders to achieve }\end{array}$} & $\begin{array}{l}\text { Rapid issue } \\
\text { detection }\end{array}$ & $\begin{array}{l}\text { The use of ICTs that enhance the speed at } \\
\text { which issues are being detected by a } \\
\text { community/community-level body (speed } \\
\text { of accessing information). }\end{array}$ & $\begin{array}{l}\text { Community-level body detecting a cattle disease } \\
\text { outbreak more quickly because of using ICTs. }\end{array}$ & $\begin{array}{l}\text { The use of ICTs that enhance the speed at which } \\
\text { issues are being detected by a } \\
\text { household/household member (speed of accessing } \\
\text { information). }\end{array}$ & $\begin{array}{l}\text { Fishermen quickly detecting a coming storm } \\
\text { while at sea due to the notification they } \\
\text { receive using their mobile phones. }\end{array}$ \\
\hline & & \begin{tabular}{|l|} 
Rapid issue \\
assessment
\end{tabular} & $\begin{array}{l}\text { The use of ICTs that enhance the speed at } \\
\text { which issues are being assessed by a } \\
\text { community/community-level body (speed } \\
\text { of decision making). }\end{array}$ & $\begin{array}{l}\text { A community weather station being able to } \\
\text { quickly assess the expected level of impact of } \\
\text { the coming heavy storm due to the use of ICTs. }\end{array}$ & $\begin{array}{l}\text { The use of ICTs that enhances the speed at which } \\
\text { issues are being assessed by a } \\
\text { household/household member (speed of decision } \\
\text { making). }\end{array}$ & $\begin{array}{l}\text { Evidence of a farmer making sales decisions } \\
\text { (e.g. selling price) quickly due to the use of } \\
\text { ICTs. }\end{array}$ \\
\hline
\end{tabular}




\begin{tabular}{|c|c|c|c|c|c|c|}
\hline & $\begin{array}{l}\text { goals in an efficient } \\
\text { manner. }\end{array}$ & $\begin{array}{l}\text { Rapid issue } \\
\text { response } \\
\text { (resource } \\
\text { mobilisation) } \\
\end{array}$ & $\begin{array}{l}\text { ICTs facilitating quick response at the } \\
\text { community level or from a community- } \\
\text { level body (speed of action). }\end{array}$ & $\begin{array}{l}\text { A community-level security body able to } \\
\text { respond quickly to an emergency due to use of } \\
\text { ICTs. }\end{array}$ & $\begin{array}{l}\text { ICTs enhancing the speed at which the response to } \\
\text { issues is happening by a household/household } \\
\text { member (speed of action). }\end{array}$ & $\begin{array}{l}\text { Evidence of farmers receiving payments and } \\
\text { remittances quickly using mobile money. }\end{array}$ \\
\hline \multirow{3}{*}{ Scale } & \multirow{3}{*}{$\begin{array}{l}\text { The breadth of assets and } \\
\text { structures a } \\
\text { household/community } \\
\text { can access to effectively } \\
\text { overcome or bounce back } \\
\text { from or adapt to the } \\
\text { effects of disturbances } \\
\text { including opportunities. }\end{array}$} & $\begin{array}{l}\text { Scale of } \\
\text { resource access }\end{array}$ & $\begin{array}{l}\text { Community-level body using ICTs to access } \\
\text { assets/resources that are either within the } \\
\text { immediate community or outside the } \\
\text { immediate community (focus on assets } \\
\text { alone). }\end{array}$ & $\begin{array}{l}\text { Farmer group accessing more market } \\
\text { opportunities and hence income due to the use } \\
\text { of ICTs. }\end{array}$ & $\begin{array}{l}\text { ICTs enabling the household to access resources } \\
\text { /assets that are either within the immediate } \\
\text { community or outside the immediate community } \\
\text { (focus on assets alone). }\end{array}$ & $\begin{array}{l}\text { Evidence of farmers accessing markets and } \\
\text { income from other districts due to information } \\
\text { and networks established due to use of ICTs. }\end{array}$ \\
\hline & & $\begin{array}{l}\text { Multi-level } \\
\text { networks }\end{array}$ & $\begin{array}{l}\text { Community-level body using ICTs to } \\
\text { connect to networks/resources that are } \\
\text { outside the immediate community } \\
\text { allowing for resources to flow between } \\
\text { them. }\end{array}$ & $\begin{array}{l}\text { Farmers' cooperative using mobile phones to } \\
\text { link (and thus establish network) with } \\
\text { suppliers/exporters in urban areas. }\end{array}$ & $\begin{array}{l}\text { ICTs enabling households to access networks that } \\
\text { are new and outside their community. }\end{array}$ & $\begin{array}{l}\text { Farmers using a mobile phone to connect with } \\
\text { exporters' collection centres, banks and } \\
\text { further actors and using this connection to } \\
\text { acquire external knowledge. }\end{array}$ \\
\hline & & $\begin{array}{l}\text { Intra-level } \\
\text { networks }\end{array}$ & $\begin{array}{l}\text { Community-level body using ICTs to link up } \\
\text { with other community-level bodies (within } \\
\text { the community) to allow a greater flow of } \\
\text { resources. }\end{array}$ & $\begin{array}{l}\text { A local NGO within a community using ICTs to } \\
\text { connect to local farmer cooperatives and assist } \\
\text { them with financial knowledge. }\end{array}$ & $\begin{array}{l}\text { ICTs enabling access to networks and individuals } \\
\text { that are within the community. }\end{array}$ & $\begin{array}{l}\text { Via phone calls with people within their } \\
\text { networks, farmers connect with buyers and } \\
\text { other actors to access information and sell } \\
\text { their produce. }\end{array}$ \\
\hline \multirow{3}{*}{$\begin{array}{l}\text { Diversity \& } \\
\text { Flexibility }\end{array}$} & \multirow{3}{*}{$\begin{array}{l}\text { Ability of the } \\
\text { household/community to } \\
\text { undertake different } \\
\text { courses of actions with } \\
\text { the resources at its } \\
\text { disposal, while enabling } \\
\text { them to innovate and } \\
\text { utilise the opportunities } \\
\text { that may arise from } \\
\text { change. }\end{array}$} & $\begin{array}{l}\text { Variety of } \\
\text { courses of } \\
\text { action }\end{array}$ & $\begin{array}{l}\text { Community/community-level body taking } \\
\text { a variety of actions to combat challenges } \\
\text { or take advantage of opportunities due to } \\
\text { information received through ICTs, or } \\
\text { using ICTs to support those activities. }\end{array}$ & $\begin{array}{l}\text { Farmer cooperative introduces loan services to } \\
\text { farmers alongside savings by making use of } \\
\text { mobile money services. }\end{array}$ & $\begin{array}{l}\text { ICTs enabling households to take } \\
\text { different/additional courses of actions to combat } \\
\text { challenges or take advantage of opportunities. }\end{array}$ & $\begin{array}{l}\text { Evidence of ICTs enabling farmers to engage in } \\
\text { additional off-farm activities. }\end{array}$ \\
\hline & & $\begin{array}{l}\text { Adaptable } \\
\text { decision-making }\end{array}$ & $\begin{array}{l}\text { Community/community-level body making } \\
\text { informed (better) decisions due to the use } \\
\text { of ICTs to combat problems or utilise } \\
\text { opportunities that may arise. }\end{array}$ & $\begin{array}{l}\text { Farmer cooperative deciding to change where to } \\
\text { sell their produce due to market information } \\
\text { received through ICTs. }\end{array}$ & $\begin{array}{l}\text { Household making informed (better) decisions due } \\
\text { to the use of ICTs to combat problems or utilise } \\
\text { opportunities that may arise. }\end{array}$ & $\begin{array}{l}\text { With new ICT-delivered information, farmers } \\
\text { make better marketing decisions based on } \\
\text { identification of higher returns. }\end{array}$ \\
\hline & & $\begin{array}{l}\text { Innovation } \\
\text { mechanism }\end{array}$ & $\begin{array}{l}\text { ICTs facilitating mechanisms (sub-system) } \\
\text { through which community/community- } \\
\text { level body can innovate. }\end{array}$ & $\begin{array}{l}\text { A farmer cooperative accessing a website of } \\
\text { ideas for better marketing. }\end{array}$ & $\begin{array}{l}\text { ICTs facilitating mechanisms (sub-system) through } \\
\text { which households innovate. }\end{array}$ & $\begin{array}{l}\text { A farmer joining an online learning course } \\
\text { about new farming techniques. }\end{array}$ \\
\hline \multirow{3}{*}{ Equality } & \multirow{3}{*}{$\begin{array}{l}\text { The extent to which the } \\
\text { household/community } \\
\text { provides equal access to } \\
\text { rights, resources and } \\
\text { opportunities to its } \\
\text { members. }\end{array}$} & $\begin{array}{l}\text { Equality of } \\
\text { distribution of } \\
\text { assets }\end{array}$ & $\begin{array}{l}\text { The use of ICTs in the community or } \\
\text { community-level body to promote equal } \\
\text { distributions of assets/resources among } \\
\text { community members. }\end{array}$ & $\begin{array}{l}\text { Evidence of a community-level body responsible } \\
\text { for land ownership using ICTs to promote } \\
\text { ownership of land among marginalised groups. }\end{array}$ & $\begin{array}{l}\text { ICTs promoting equal balance of ownership and } \\
\text { access to assets within households. }\end{array}$ & $\begin{array}{l}\text { Evidence of mobile phones increasing the } \\
\text { proportion of productive assets owned by } \\
\text { women within households. }\end{array}$ \\
\hline & & $\begin{array}{l}\text { Inclusiveness } \\
\text { and } \\
\text { participation }\end{array}$ & $\begin{array}{l}\text { The use of ICTs to increase } \\
\text { participation/inclusiveness of community } \\
\text { or marginalised groups within the } \\
\text { community, e.g. women. }\end{array}$ & $\begin{array}{l}\text { ICT intervention that promotes knowledge of } \\
\text { women's groups in communities/villages. }\end{array}$ & $\begin{array}{l}\text { The use of ICTs that increases } \\
\text { participation/inclusiveness of households or } \\
\text { household members. }\end{array}$ & $\begin{array}{l}\text { The use of mobile money services that } \\
\text { increases financial inclusion of women in rural } \\
\text { households. }\end{array}$ \\
\hline & & $\begin{array}{l}\text { Openness and } \\
\text { accountability }\end{array}$ & $\begin{array}{l}\text { The use of ICTs to increase openness and } \\
\text { accountability in the community or } \\
\text { community-level body. }\end{array}$ & $\begin{array}{l}\text { The use of ICTs in a community-level body to } \\
\text { promote openness by reporting its activities to } \\
\text { farmers. }\end{array}$ & $\begin{array}{l}\text { The use of ICTs to increase openness and } \\
\text { accountability within the household. }\end{array}$ & $\begin{array}{l}\text { The use of ICTs to promote openness of } \\
\text { household spending, e.g. using shared mobile } \\
\text { money services. }\end{array}$ \\
\hline
\end{tabular}




\section{References}

Adger, W. (2003). Social capital, collective action, and adaptation to climate change, Economic Geography, 79(4), 387-404.

Ajwang, F. O. (2014). Market in their palms?: exploring smallholder farmers' use of mobile phone farming applications and their effect on the farmers' farming, marketing and wellbeing: a case study of selected counties in Kenya. MPhil. Massey University: Palmerston North, New Zealand. [1]

Aker, J. C., \& Ksoll, C. (2016). Can mobile phones improve agricultural outcomes? Evidence from a randomized experiment in Niger, Food Policy, 60, 44-51. [2]

Aker, J. C., \& Mbiti, I. M. (2010). Mobile phones and economic development in Africa, Journal of Economic Perspectives, 24(3), 207-32.

Ali, J., \& Kumar, S. (2011). Information and communication technologies (ICTs) and farmers' decision-making across the agricultural supply chain, International Journal of Information Management, 31(2), 149-159. [3]

Arinloye, D. D. A., Linnemann, A. R., Hagelaar, G., Coulibaly, O., \& Omta, O. S. (2015). Taking profit from the growing use of mobile phone in Benin: a contingent valuation approach for market and quality information access, Information Technology for Development, 21(1), 44-66. [4]

Asongu, S. A., Nwachukwu, J. C., \& Orim, S. M. I. (2018). Mobile phones, institutional quality and entrepreneurship in Sub-Saharan Africa, Technological Forecasting and Social Change, 131, 183-203.

Baardewijk, M. (2017). The impact of mobile phone use and IKSL's audio messages on the asset base of poor farmers in Lucknow, India, The Electronic Journal of Information Systems in Developing Countries, 79(1), 1-17. [5]

Baird, T. D., \& Hartter, J. (2017). Livelihood diversification, mobile phones and information diversity in northern Tanzania, Land Use Policy, 67, 460-471. [6]

Baliwada, H., Gills, R., \& Sharma, J. P. (2014). 'Climate resilient technologies for sustainable agriculture', in Shukla, J. P. (ed.) Technologies for sustainable rural development: having potential of socio-economic upliftment. Allied Publishers: New Delhi, India, pp. 256- 263.

Batista, C., \& Vicente, P. C. (2017). Improving access to savings through mobile money: experimental evidence from smallholder farmers in Mozambique, NOVAAFRICA Working Paper no. 1705. Nova School of Business and Economics, Nova University of Lisbon: Lisbon, Portugal. [7]

Baumüller, H. (2015). Assessing the role of mobile phones in offering price information and market linkages: the case of M-Farm in Kenya, The Electronic Journal of Information Systems in Developing Countries, 68(1), 1-16. [8]

Baumüller, H. (2018). The little we know: an exploratory literature review on the utility of mobile phone-enabled services for smallholder farmers, Journal of International Development, 30(1), 134-154.

Belal, A., El-Ramady, H., Mohamed, E., \& Saleh, A. (2014). Drought risk assessment using remote sensing and GIS techniques, Arabian Journal of Geosciences, 7(1), 35-53.

Bender, D. R. (1967). A refinement of the concept of household: families, co-residence, and domestic functions, American Anthropologist, 69(5), 493-504.

Béné, C. (2013). Towards a quantifiable measure of resilience, IDS Working Paper volume 2013 number 434. Institute of Development Studies: Brighton, UK. Available at: https://doi.org/10.1111/i.2040-0209.2013.00434.x. 
Béné, C., Al-Hassan, R. M., Amarasinghe, O., Fong, P., Ocran, J., Onumah, E., Ratuniatad, R., Truong Van Tuyene, T. R, McGregor J. A., \& Mills, D. J. (2016). Is resilience socially constructed? Empirical evidence from Fiji, Ghana, Sri Lanka, and Vietnam, Global Environmental Change, 38, 153-170.

Berkes, F., \& Ross, H. (2013). Community resilience: toward an integrated approach, Society \& Natural Resources, 26(1), 5-20.

Boettiger, S., Toyama, K., \& Abed, R. (2012). Natural obsolescence of village phone, Proceedings of the Fifth International Conference on Information and Communication Technologies and Development, Atlanta, Georgia, USA. 12-15 March 2012. ACM. pp. 221-229. Available at: $10.1145 / 2160673.2160702$.

Boland, A., Cherry, G., \& Dickson, R. (2017). Doing a systematic review: a student's guide. 2nd edn. Sage: London.

Brown, K. (2015). Resilience, development and global change. Routledge: Abingdon, UK.

Brown, K., \& Westaway, E. (2011). Agency, capacity, and resilience to environmental change: lessons from human development, well-being, and disasters, Annual Review of Environment and Resources, 36, 321-342.

Bukenya, B., \& Yanguas, P. (2013). Building state capacity for inclusive development: the politics of public sector reform, ESID working paper no. 25. ESID, University of Manchester: Manchester, UK.

Burrell, J., \& Oreglia, E. (2015). The myth of market price information: mobile phones and the application of economic knowledge in ICTD, Economy and Society, 44(2), 271-292.

Carmody, P. (2013). A knowledge economy or an information society in Africa? Thintegration and the mobile phone revolution, Information Technology for Development, 19(1), 24-39.

Chambers, R. (1997). Whose reality counts? : putting the first last. Intermediate Technology Publications: London.

Checkland, P. (1981). Systems thinking, systems practice. Wiley: Chichester, UK.

Cole, S., \& Fernando, A. N. (2012). The value of advice: evidence from mobile phone-based agricultural extension, Harvard Business School working paper no 13-047. Harvard Business School, Harvard University: Boston, MA. [9]

CTA. (2014). ICTs improving family farming: building resilience for family farming. Technical Centre for Agricultural and Rural Cooperation ACP-EU (CTA): Wageningen, Netherlands.

Dannenberg, P., \& Lakes, T. (2013). The use of mobile phones by Kenyan export-orientated small-scale farmers: insights from fruit and vegetable farming in the Mt. Kenya region, Economia Agro-Alimentare, 15(3), 55-75. [10]

Deloitte. (2012). E-transform Africa: agriculture sector study: sector assessment and opportunities for ICT. Deloitte: New York, NY. Available at: http://siteresources.worldbank.org/EXTINFORMATIONANDCOMMUNICATIONANDTECH NOLOGIES/Resources/282822-1346223280837/Agriculture FullReport.pdf.

Dey, B. L., Prendergast, R., \& Newman, D. (2008). How can ICTs be used and appropriated to address agricultural information needs of Bangladeshi farmers?, GlobDev 2008, 21. [11]

Douxchamps, S., Debevec, L., Giordano, M., \& Barron, J. (2017). Monitoring and evaluation of climate resilience for agricultural development-A review of currently available tools, World Development Perspectives, 5, 10-23.

Duncombe, R. (2006). Analysing ICT applications for poverty reduction via microenterprise using the livelihoods framework, Development Informatics Working Paper no. 27. Centre 
for Development Informatics, University of Manchester: Manchester, UK. Available at: https://www.gdi.manchester.ac.uk/research/publications/di/di-wp27/.

Duncombe, R. (2014). Understanding the impact of mobile phones on livelihoods in developing countries, Development Policy Review, 32(5), 567-588.

Duncombe, R. (2016). Mobile phones for agricultural and rural development: a literature review and suggestions for future research, The European Journal of Development Research, 28(2), 213-235.

Folke, C., Carpenter, S., Walker, B., Scheffer, M., Chapin, T., \& Rockström, J. (2010). Resilience thinking: integrating resilience, adaptability and transformability, Ecology and Society, 15(4), 20.

Foster, C., \& Heeks, R. (2013). Analyzing policy for inclusive innovation: the mobile sector and base-of-the-pyramid markets in Kenya, Innovation and Development, 3(1), 103-119.

Fu, X., \& Akter, S. (2016). The impact of mobile phone technology on agricultural extension services delivery: evidence from India, The Journal of Development Studies, 52(11), 1561-1576. [12]

Furuholt, B., \& Matotay, E. (2011). The developmental contribution from mobile phones across the agricultural value chain in rural Africa, The Electronic Journal of Information Systems in Developing Countries, 48(1), 1-16. [13]

Garcia, V.B.S. \& Fan, Q. (2015). Information access and smallholder farmers' selling decisions in Peru, Agricultural \& Applied Economics Association 2015 conference, San Francisco, CA. 26-28 July 2015. Available at: https://ageconsearch.umn.edu/record/205380/.

Goyal, A. (2010). Information, direct access to farmers, and rural market performance in central India, American Economic Journal, 2(3), 22-45.

Grothmann, T., \& Patt, A. (2005). Adaptive capacity and human cognition: the process of individual adaptation to climate change, Global Environmental Change, 15(3), 199-213.

GSMA. (2018). The mobile economy: Sub-Saharan Africa 2018. GSMA: London. Available at: https://www.gsmaintelligence.com/research/?file=809c442550e5487f3b1d025fdc70e23 b\&download.

Gyan, S. (2018). Exploring uses of mobile phones in pineapple production and its livelihood benefits for Farmers in Akwapim south district, Ghana. BSc. Ashesi University College: Berekuso, Ghana. [14]

Hallegatte, S., Vogt-Schilb, A., Bangalore, M., \& Rozenberg, J. (2017). Unbreakable: building the resilience of the poor in the face of natural disasters. World Bank: Washington, DC.

Haworth, B., Biggs, E., Duncan, J., Wales, N., Boruff, B., \& Bruce, E. (2018). Geographic information and communication technologies for supporting smallholder agriculture and climate resilience, Climate, 6(4), 97.

Heeks, R. \& Molla, A. (2009). Impact assessment of ICT-for-development projects: a compendium of approaches, Development Informatics Working Paper no. 36. Centre for Development Informatics, University of Manchester: Manchester, UK. Available at: https://www.gdi.manchester.ac.uk/research/publications/di/di-wp36/.

Heeks, R. (2010). Do information and communication technologies (ICTs) contribute to development?, Journal of International Development, 22(5), 625-640.

Heeks, R. (2014a). From the MDGS to the post-2015 agenda: analysing changing development priorities, Development Informatics Working Paper no. 56. Centre for Development Informatics, University of Manchester: Manchester, UK. Available at: https://www.gdi.manchester.ac.uk/research/publications/di/di-wp56/. 
Heeks, R. (2014b). Future priorities for development informatics research from the post-2015 development agenda, Development Informatics Working Paper no. 57. Centre for Development Informatics, University of Manchester: Manchester, UK. Available at: https://www.gdi.manchester.ac.uk/research/publications/di/di-wp57/.

Heeks, R. (2016). Examining "digital development": the shape of things to come?, Development Informatics Working Paper no. 64. Centre for Development Informatics, University of Manchester: Manchester, UK. Available at: https://www.gdi.manchester.ac.uk/research/publications/di/di-wp64/.

Heeks, R. (2018). Information and communication technology for development (ICT4D). Taylor and Francis: London.

Heeks, R. \& Krishna, S. (2016). ICTs and hope for development: a theoretical framework, The Electronic Journal of Information Systems in Developing Countries, 77(4), 1-19.

Heeks, R., \& Ospina, A. V. (2012). ICTs, climate change and development: themes and strategic actions. Centre for Development Informatics: Manchester, UK.

Heeks, R., \& Ospina, A.V. (2015). Analysing urban community informatics from a resilience perspective, Journal of Community Informatics, 11(1), 1-14.

Heeks, R., \& Ospina, A.V. (2016a). Benchmarking, visualising and strengthening ICTs' impact on urban community resilience: a Ugandan case study. Centre for Development Informatics, University of Manchester: Manchester, UK.

Heeks, R., \& Ospina, A.V. (2016b). Benchmarking, visualising and strengthening ICTs' impact on urban community resilience: a Costa Rica case study. Centre for Development Informatics, University of Manchester: Manchester, UK.

Heeks, R., \& Ospina, A.V. (2019). Conceptualising the link between information systems and resilience: a developing country field study, Information Systems Journal, 29(1), 70-96.

Heeks, R. \& Shekhar, S. (2019a) Analysing urban platforms and inequality through a "platform justice" lens, paper presented at international workshop on Urban Platforms and the Future City, University of Manchester, 28 Feb-1 Mar

Heeks, R. \& Shekhar, S. (2019b). Datafication, development and marginalised urban communities: an applied data justice framework, Information, Communication \& Society, 22(7), 992-1011.

High, C., Pelling, M., \& Nemes, G. (2005). Understanding informal institutions: networks and communities in rural development, Transition in Agriculture, Agricultural Economics in Transition II, Budapest, Hungary. 28-29 October 2005. Institute of Economics, Hungarian Academy of Sciences. pp. 1-20. Available at: http://oro.open.ac.uk/2683/.

Hurrelmann, K. (1988). Social structure and personality development: the individual as a productive processor of reality. Cambridge University Press: Cambridge, UK.

Jack, W., \& Suri, T. (2011). Mobile money: the economics of M-PESA, NBER working paper no. 16721. National Bureau of Economic Research: Cambridge, USA. Available at: https://doi.org/10.3386/w16721.

Jimenez, D., \& Ramirez-Villegas, J. (2018). “Unlocking big data's potential to strengthen farmers' resilience: the platform for big data in agriculture", in Ospina, A.V. (ed.) Big data for resilience storybook: experiences integrating big data into resilience programming. International Institute for Sustainable Development: Winnipeg, MB, pp. 97-108.

Jones, L., \& Tanner, T. (2017). 'Subjective resilience': using perceptions to quantify household resilience to climate extremes and disasters, Regional Environmental Change, 17(1), 229-243. 
Kanbur, R., \& Venables, A. J. (eds.). (2005). Spatial inequality and development. Oxford University Press: Oxford, UK.

Khabsa, M., \& Giles, C. L. (2014). The number of scholarly documents on the public web, Plos One, 9(5).

Kiiza, B., \& Pederson, G. (2012). ICT-based market information and adoption of agricultural seed technologies: insights from Uganda, Telecommunications Policy, 36(4), 253-259. [15]

Kikulwe, E. M., Fischer, E., \& Qaim, M. (2014). Mobile money, smallholder farmers, and household welfare in Kenya, PloS One, 9(10). [16]

Kimhi, S. (2016). Levels of resilience: associations among individual, community, and national resilience. Journal of Health Psychology, 21(2), 164-170.

Kirui, O. K., Okello, J. J., Nyikal, R. A., \& Njiraini, G. W. (2013). Impact of mobile phone-based money transfer services in agriculture: evidence from Kenya, Quarterly Journal of International Agriculture, 52(892-2016-65177), 141-162. [17]

Krone, M., Dannenberg, P., \& Nduru, G. (2016). The use of modern information and communication technologies in smallholder agriculture: examples from Kenya and Tanzania, Information Development, 32(5), 1503-1512. [18]

Labonne, J., \& Chase, R. S. (2009). The power of information: the impact of mobile phones on farmers' welfare in the Philippines, Policy Research Working Paper no. 4996. The World Bank: Washington, DC. [19]

Lee, K. H., \& Bellemare, M. F. (2013). Look who's talking: the impacts of the intrahousehold allocation of mobile phones on agricultural prices, The Journal of Development Studies, 49(5), 624-640.

Levine, S. (2014). Assessing resilience: why quantification misses the point, HPG Working Paper. Overseas Development Institute: London, UK. Available at: https://www.odi.org/sites/odi.org.uk/files/odi-assets/publications-opinionfiles/9049.pdf.

Lewis, A. L., Baird, T. D., \& Sorice, M. G. (2016). Mobile phone use and human-wildlife conflict in northern Tanzania, Environmental Management, 58(1), 117-129. [20]

Lipper, L., McCarthy, N., Zilberman, D., Asfaw, S., \& Branca, G. (eds.). (2018). Climate smart agriculture: building resilience to climate change. Springer: Cham.

Loudon, M. (2016). A platform studies approach to the role of technology in the ICTD ecosystem: the SMS in M4D interventions, Information Technology for Development, 22(sup1), 7-25.

Lwasa, S., Asingwire, N., Okello, J. J., \& Kiwanuka, J. (2011). Awareness of ICT-based projects and the intensity of use of mobile phones among smallholder farmers in Uganda: the case of Mayuge and Apac districts, International Journal of ICT Research and Development in Africa, 2(2), 26-38.

Lwoga, E. T. (2010). Bridging the agricultural knowledge and information divide: the case of selected telecenters and rural radio in Tanzania, The Electronic Journal of Information Systems in Developing Countries, 43(1), 1-14. [21]

Manfre, C., \& Nordehn, C. (2013). Exploring the promise of information and communication technologies for women farmers in Kenya, Cultural Practice, 1-10. [22]

Martin, B. L., \& Abbott, E. (2011). Mobile phones and rural livelihoods: diffusion, uses, and perceived impacts among farmers in rural Uganda, Information Technologies \& International Development, 7(4), 17-34. [23] 
Masuka, B., Matenda, T., Chipomho, J., Mapope, N., Mupeti, S., Tatsvarei, S., \& Ngezimana, W. (2016). Mobile phone use by small-scale farmers: a potential to transform production and marketing in Zimbabwe, South African Journal of Agricultural Extension, 44(2), 121135. [24]

Masuki, K. F. G., Kamugisha, R., Mowo, J. G., Tanui, J., Tukahirwa, J., Mogoi, J., \& Adera, E. O. (2010, March). Role of mobile phones in improving communication and information delivery for agricultural development: lessons from South Western Uganda, International Federation for Information Processing (IFIP), Technical Commission 9 Relationship Between Computers and Society, Makerere University, Uganda. 22-23 March 2010. Available at: https://www.researchgate.net/publication/260402865. [25]

Matuha, M. (2015). Mobile phone use in Ugandan aquaculture: farmer experiences and aspirations. MSc. Auburn University: Auburn, AL. [26]

Mittal, S. (2015). Mobile phones based agro-advisories role in gender empowerment, 2015 Conference, Milan, Italy. 9-14 August 2015. Available at: https://ideas.repec.org/p/ags/iaae15/212467.html. [30]

Mittal, S., \& Mehar, M. (2012). How mobile phones contribute to growth of small farmers? Evidence from India, Quarterly Journal of International Agriculture, 51(892-2016-65169), 227-244. [29]

Mittal, S., \& Tripathi, G. (2009). Role of mobile phone technology in improving small farm productivity, Agricultural Economics Research Review, 22(347-2016-16874), 451-460. [27]

Mittal, S., Gandhi, S., \& Tripathi, G. (2010). Socio-economic impact of mobile phones on Indian agriculture, Working paper no. 246. Indian Council for Research on International Economic Relations: New Delhi, India. [28]

Mohamad, M. R. A., \& Gombe, M. I. (2017). e-Agriculture revisited: a systematic literature review of theories, concept, practices, methods, and future trends, British Academy of Management Annual Conference, Warwick Business School, UK. 5-7 September 2017. Available at: http://usir.salford.ac.uk/id/eprint/43648/.

Moher, D., Liberati, A., Tetzlaff, J., \& Altman, D. G. (2009). Preferred reporting items for systematic reviews and meta-analyses: the PRISMA statement, Annals of Internal Medicine, 151(4), 264-269.

Molony, T. (2006). "I don't trust the phone; it always lies": trust and information and communication technologies in Tanzanian micro-and small enterprises, Information Technologies \& International Development, 3(4), 67-83.

Molony, T. (2008). Running out of credit: the limitations of mobile telephony in a Tanzanian agricultural marketing system, The Journal of Modern African Studies, 46(4), 637-658.

Mtega, W. P., \& Msungu, A. C. (2013). Using information and communication technologies for enhancing the accessibility of agricultural information for improved agricultural production in Tanzania, The Electronic Journal of Information Systems in Developing Countries, 56(1), 1-14. [31]

Muktar, B. G., Man, N., Kamaruzzaman, N. H., Samah, A. A., \& Umar, S. (2018a). Fishers ICTs use for early warning reception, it's effect on livelihood resilience and sustainability in east coast Malaysia, Journal of Agriculture and Veterinary Science, 11(1), 63-72.

Muktar, B. G., Man, N., Saleh, J. M., \& Daneji, M. I. (2018b). Evaluation of ICTs access, use and preferences for livelihood resilience: results from a survey of Malaysian fisher folks, The Journal of Agricultural Education and Extension, 24(4), 377-388. 
Munyegera, G. K., \& Matsumoto, T. (2016). Mobile money, remittances, and household welfare: panel evidence from rural Uganda, World Development, 79, 127-137. [32]

Murphy, J. T., \& Carmody, P. (2015). Africa's information revolution: technical regimes and production networks in South Africa and Tanzania. John Wiley \& Sons: Chichester, UK.

Muto, M., \& Yamano, T. (2009). The impact of mobile phone coverage expansion on market participation: panel data evidence from Uganda, World Development, 37(12), 18871896. [33]

Mwakaje, A. G. (2010). Information and communication technology for rural farmers market access in Tanzania, Journal of Information Technology Impact, 10(2), 111-128. [34]

Mwantimwa, K. (2019). Use of mobile phones among agro-pastoralist communities in Tanzania, Information Development, 35(2), 230-244. [35]

Ogbeide, O. A., \& Ele, I. (2015). Smallholder farmers and mobile phone technology in SubSahara agriculture, Mayfair Journal of Information and Technology Management in Agriculture, 1(1), 1-19. [36]

Ogunniyi, M. D., \& Ojebuyi, B. R. (2016). Mobile phone use for agribusiness by farmers in Southwest Nigeria, Journal of Agricultural Extension, 20(2), 172-187. [37]

Oliver, S.R., Rees, R.W., Clarke-Jones, L., Milne, R., Oakley, A.R., Gabbay, J., Stein, K., Buchanan, P. and Gyte, G. (2008). A multidimensional conceptual framework for analysing public involvement in health services research, Health Expectations, 11(2), 204-204.

Ospina, A.V. (2013). Climate change adaptation and developing country livelihoods: the role of information and communication technologies. PhD. University of Manchester: Manchester, UK.

Ospina, A. V., Heeks, R., Camacho, K., Calvo, M., Zúñiga, V., Barrios, P., \& Rojas, I. (2016). Benchmarking urban community resilience: piloting the Resilience Assessment Benchmarking and Impact Toolkit (RABIT) in Costa Rica. Centre for Development Informatics, University of Manchester: Manchester, UK. Available at: http://www.niccd.org/wp-content/uploads/2017/11/RABITCostaRicaFullCaseStudy.pdf

Ospina, A.V. \& Heeks, R. (2010). Linking ICTs and climate change adaptation: a conceptual framework for e-resilience and e-adaptation. Centre for Development Informatics: Manchester, UK. Available at: https://www.research.manchester.ac.uk/portal/files/33529974/FULL TEXT.PDF.

Ospina, A.V. \& Heeks, R. (2016). Resilience Assessment Benchmarking And Impact Toolkit (RABIT): implementation handbook. Centre for Development Informatics, University of Manchester: Manchester, UK. Available at: http://www.niccd.org/wpcontent/uploads/2017/11/RABITHandbookV1a.pdf

Ozor, N. (2015). Improving agricultural productivity and resilience to climate change using the Land Potential Knowledge System (LandPKS) mobile technology. Technical Centre for Agricultural and Rural Cooperation (CTA): Wageningen, Netherlands.

Ozor, N., Acheampong, E. N., Herrick, J., \& Beh, A. (2015). Using the Land Potential Knowledge System (LandPKS) mobile technology for agricultural productivity and resilience. African Technology Policy Studies Network: Nairobi, Kenya.

Phillips, J. (2003). 'Determinants of forecast use among communal farmers in Zimbabwe', in O'Brien, K. \& Vogel, C. (eds.) Coping with variability: the use of seasonal climate forecasts in southern Africa. Ashgate: Farnham, UK. pp. 110-28.

Pieterse, J. N. (2010). Development theory. 2nd edn. Sage Publications: London. 
Piontak, R. (2012). Calling for better crops: an exploration of social upgrading through two mobile phone-based agriculture extension projects in Uganda. MPhil. University of Cape Town: Cape Town South Africa. [38]

Pretty, J. N. (2003). Social capital and connectedness: issues and implications for agriculture, rural development and natural resource management in ACP countries. CTA: Wageningen, Netherlands.

Quandt, A. (2018). Measuring livelihood resilience: the household livelihood resilience approach (HLRA). World Development, 107, 253-263.

Roberts, E., Farrington, J., \& Skerratt, S. (2015). Evaluating new digital technologies through a framework of resilience, Scottish Geographical Journal, 131(3-4), 253-264.

Salia, M., Nsowah-Nuamah, N. N., \& Steel, W. F. (2011). Effects of mobile phone use on artisanal fishing market efficiency and livelihoods in Ghana, The Electronic Journal of Information Systems in Developing Countries, 47(1), 1-26. [39]

Sambasivan, N., Azad, G., Aoki, P. M., \& Mitra, S. S. (2016). We call it hi-fi: exposing Indian households to high speed broadband wireless internet, Proceedings of the Eighth International Conference on Information and Communication Technologies and Development, Michigan, USA. 3-6 June 2016. Available at: https://doi.org/10.1145/2909609.2909651.

Scott, M. (2013). Resilience: a conceptual lens for rural studies?, Geography Compass, 7(9), 597-610.

Sekabira, H., \& Qaim, M. (2017a). Mobile money, agricultural marketing, and off-farm income in Uganda, Agricultural Economics, 48(5), 597-611. [40]

Sekabira, H., \& Qaim, M. (2017b). Can mobile phones improve gender equality and nutrition? Panel data evidence from farm households in Uganda, Food Policy, 73, 95103. [41]

Sen, A. (1999). Development as freedom. Oxford University Press: Oxford, UK.

Sewell, W. H. (1992). A theory of structure: duality, agency, and transformation, American Journal of Sociology, 98(1), 1-29.

Shaffril, H. A., Omar, S. Z., D'Silva, J. L., \& Bolong, J. (2015). Mapping the patterns of mobile phone usage among fishermen in Malaysia, Information Technology for Development, 21(4), 543-554. [42]

Shilling, C. (1992). Reconceptualising structure and agency in the sociology of education: structuration theory and schooling, British Journal of Sociology of Education, 13(1), 6987.

Sife, A. S., Kiondo, E., \& Lyimo-Macha, J. G. (2010). Contribution of mobile phones to rural livelihoods and poverty reduction in Morogoro region, Tanzania, The Electronic Journal of Information Systems in Developing Countries, 42(1), 1-15. [43]

Sina, D., Chang-Richards, A. Y., Wilkinson, S., \& Potangaroa, R. (2019). A conceptual framework for measuring livelihood resilience: relocation experience from Aceh, Indonesia. World Development, 117, 253-265.

Smith, L. C., \& Frankenberger, T. R. (2018). Does resilience capacity reduce the negative impact of shocks on household food security? World Development, 102, 358-376.

Tadesse, G., \& Bahiigwa, G. (2015). Mobile phones and farmers' marketing decisions in Ethiopia, World Development, 68, 296-307. [44]

Tenhunen, S. (2008). Mobile technology in the village: ICTs, culture, and social logistics in India. Journal of the Royal Anthropological Institute, 14(3), 515-534. 
Thiede, B. (2016). Resilience and development among ultra-poor households in rural Ethiopia, Resilience, 4(1), 1-13.

Thomas, J., \& Harden, A. (2008). Methods for the thematic synthesis of qualitative research in systematic reviews, BMC Medical Research Methodology, 8(1).

Torero, M. (2014). Information and communication technologies: farmers, markets, and the power of connectivity. International Food Policy Research Institute: Washington, DC. Available at: http://www.ifpri.org/publication/information-and-communicationtechnologies-farmers-markets-and-power-connectivity.

Verma, H., Moder, F., \& Shaik, Z. H. (2017). Crafting climate resilience for people at bottom of pyramid using digital innovation, International Journal of Environmental Science and Development, 8(10), 742-747.

Walsham, G. (2017). ICT4D research: reflections on history and future agenda, Information Technology for Development, 23(1), 18-41.

Westermann, O., Förch, W., Thornton, P., Körner, J., Cramer, L., \& Campbell, B. (2018). Scaling up agricultural interventions: case studies of climate-smart agriculture, Agricultural Systems, 165, 283-293.

Wilson, G. (2010). Multifunctional 'quality'and rural community resilience. Transactions of the Institute of British Geographers, 35(3), 364-381.

Wilson, G. (2012). Community resilience, globalization, and transitional pathways of decision-making, Geoforum, 43(6), 1218-1231.

World Bank. (2012). The transformational use of information and communication technologies in Africa. World Bank: Washington, DC.

World Bank. (2014). ICT as an enabler of transformation in Ethiopia. World Bank: Washington, DC.

World Bank. (2018). The role of digital identification in agriculture: emerging applications. World Bank: Washington, DC.

Wyche, S., Simiyu, N., \& Othieno, M. E. (2016). Mobile phones as amplifiers of social inequality among rural Kenyan women, ACM Transactions on Computer-Human Interaction, 23(3), 1-19.

Zanello, G. (2012). Mobile phones and radios: effects on transactions costs and market participation for households in northern Ghana, Journal of Agricultural Economics, 63(3), 694-714. [45]

Zhao, Y., Li S., Zhang Y. (2005). 'Early detection and monitoring of drought and flood in China using remote sensing and GIS', in Sivakumar M.V., Motha R.P., Das H.P. (eds.) Natural disasters and extreme events in agriculture. Springer: Berlin. pp.305-317.

Zheng, Y., Hatakka, M., Sahay, S., \& Andersson, A. (2018). Conceptualizing development in information and communication technology for development (ICT4D), Information Technology for Development, 24(1), 1-14. 